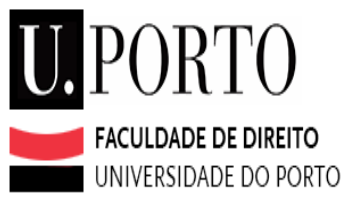

\title{
A liberdade religiosa dos professores, na Alemanha - A proibição geral do uso do véu islâmico por professoras de escolas públicas, em especial
}

\author{
Cassia Juliana de Souza Monteiro \\ Faculdade de Direito da Universidade do Porto \\ Mestrado em Direito - Ciências Jurídico-Políticas \\ Dissertação realizada sob a orientação do \\ Professor Doutor Paulo Pulido Adragão
}

Setembro de 2018 

A Nina Sophie Genefort Monteiro 



\section{Agradecimentos}

A Deus, início e fim de tudo.

À espiritualidade superior, meus guias, meus protetores e minha Mãe Elenira de Obá, por toda proteção, força e luz na realização deste trabalho e na vida. Axé!

Aos meus pais, irmãos, cunhada e amada sobrinha, por todo amor que representam em minha vida.

A Fernando Brito, Manuel Jorge e Florian, pelo indispensável apoio no início deste Mestrado.

Aos colegas da Universidade Federal de Minas Gerais, por toda ajuda no processo de autorização da licença que possibilitou minha vinda para Portugal.

Aos colegas da Faculdade de Direito da Universidade do Porto, por todo o companheirismo nos estudos e amizade.

Ao Sheikh Davi Munir, ao Professor Mahmoud, à Senhora Nadia Ettaouass e ao Senhor Islam Reis, pelas gentis entrevistas concedidas no processo desta pesquisa.

A Cora Kalenga e família, pela preciosa ajuda na realização do inquérito aos professores alemães.

Ao Professor Doutor Paulo Pulido Adragão, por ter-me iniciado no estudo da liberdade religiosa e pela generosa e comprometida orientação na realização desta pesquisa e dissertação.

Ao querido Wojciech Lysakowski, pelo carinho, companheirismo e ajuda ao longo destes anos em Portugal. 



\section{Resumo}

Mãe de todas as liberdades, a liberdade religiosa enfrenta, desde sempre, grandes desafios e pressões para manter-se viva. Atualmente, em que a sociedade se mostra cada vez mais plural e diversificada em termos culturais e com tradições completamente diversas compartilhando o mesmo espaço territorial, torna-se imperativa a proteção do livre exercício do direito fundamental à liberdade religiosa.

Um dos problemas encarados pela liberdade religiosa, em particular pela confissão muçulmana, é a crescente restrição à liberdade de exteriorização individual da fé, através da utilização de símbolos e outros objetos de cunho religioso em instituições públicas, notadamente, em escolas públicas.

O nosso objetivo principal com este estudo é mostrar, a partir do acórdão proferido pelo Tribunal Constitucional alemão em 27 de janeiro de 2015, que a liberdade religiosa dos professores, enquanto direito fundamental, é de extrema importância para o desenvolvimento de uma sociedade, não devendo ser preterida por um mero risco abstrato de violação de outros direitos ou princípios.

Nesta dissertação, analisaremos o julgado supracitado, onde foi discutido o direito de duas profissionais da educação, seguidoras da fé islâmica, utilizarem o hijab no local de trabalho. Faremos, no seguimento, uma análise e comparação dos entendimentos do termo "neutralidade", adotados por vários Estados para os fins de atuação dos mesmos perante a promoção e a garantia da liberdade religiosa dos cidadãos.

Realizaremos, ainda, um estudo da sociedade alemã recente, relativamente ao fenómeno da imigração e dos seus efeitos, principalmente no que respeita ao aumento da população muçulmana, e a como funcionam as relações Igreja-Estado na Alemanha.

Com apoio nas razões adotadas pelo Tribunal Constitucional alemão para decidir o caso em foco, finalizaremos com conclusões sobre o direito ao uso de símbolos religiosos pelas professoras das escolas públicas, expressão da sua liberdade de manifestação de crenças, enquanto direito fundamental, e seu papel na formação de uma sociedade democrática, num Estado de Direito.

Esperamos que este estudo possa contribuir para o esclarecimento de outros Estados em relação à importância do livre exercício da liberdade religiosa para todos os indivíduos, independentemente da confissão seguida.

Palavras-chave: liberdade religiosa; Islão; muçulmano; véu; hijab; professora; escola pública; Alemanha; risco abstrato. 


\section{Abstract}

Mother of all freedoms, religious liberty has always faced great challenges and pressures in order to keep itself alive. Nowadays, society is increasingly plural and culturally diverse; with completely different traditions sharing the same territorial space, it is imperative to protect the free exercise of the fundamental right to religious freedom.

One of the problems faced by religious freedom, particularly by Muslim religion, is the growing restriction on the freedom of individual expression of faith using symbols and other religious objects in public institutions, notably in public schools.

Our main objective with this study is to show, from the case of the German Constitutional Court of January 27, 2015, that religious freedom of teachers, as a fundamental right, is extremely important for the development of a society and should not be deprecated by an abstract risk of violation of other rights and principles.

We will, thus, analyze this decision of the German Constitutional Court, dated from January the 27th, 2015, in which the right of two Muslim employees at public schools to use hijab in the workplace was discussed. We will follow up on analyzing the meaning of the term "neutrality" adopted by several States in order to promote and guarantee religious freedom of citizens and its impact on the society.

We will also carry out a study of the German society, covering aspects of immigration and its effects, especially with regard to the increase of the Muslim population, and how Church-State relations work in Germany.

Based on the German Constitutional Court's arguments, we will finalize this research with conclusions about the right to the use of religious symbols by public school teachers, expression of their freedom to manifest beliefs as a fundamental right, and their role in the formation of a democratic society, in a State of Law.

We hope that this study may contribute to the clarification of other States regarding the importance of the free exercise of religious freedom for all individuals, regardless of the religion followed.

Key words: religious freedom; Islam; muslim; headscarf; hijab; teacher; public school; Germany; abstract risk. 


\section{Índice}

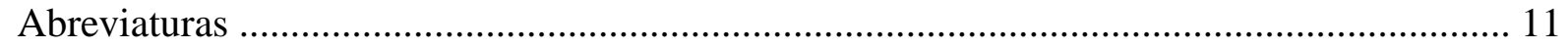

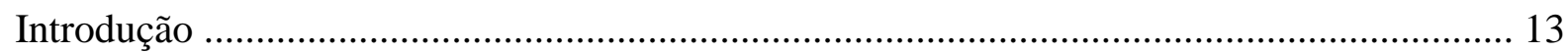

Capítulo I - O véu islâmico: código de vestuário ou símbolo religioso? ............................... 17

Capítulo II - O Acórdão do Tribunal Constitucional alemão (BvR 471/10 e BvR 1181/10), de 27 de janeiro de 2015 - apresentação do caso ............................................................. 23

Capítulo III - A liberdade religiosa e a neutralidade do Estado em visões diversas,

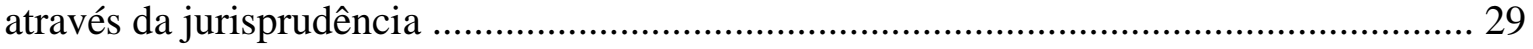

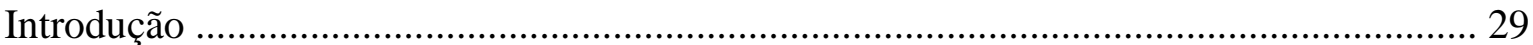

a) O Acórdão n 174/93, de 17 de fevereiro de 1993, do Tribunal Constitucional português

b) O Acórdão Dahlab v. Suíça, de 15 de fevereiro de 2001, do

Tribunal Europeu dos Direitos do Homem................................................................... 33

c) Neutralidade-colaboração v. neutralidade-negação ................................................... 35

Capítulo IV - A Alemanha e o tratamento da liberdade religiosa ......................................... 43

a) Panorama da Alemanha atual: imigrantes e população - o islamismo na Alemanha .. 43

b) O sistema alemão de relações Igreja-Estado ................................................................ 49

c) A Lei Fundamental da Alemanha e as restrições a direitos, liberdades e garantias ..... 53

d) A decisão do Acórdão do Tribunal Constitucional alemão de 27 de janeiro de 2015 - análise crítica .................................................... 61

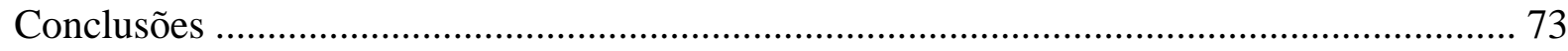

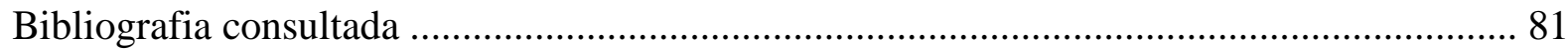

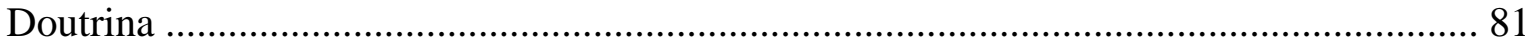

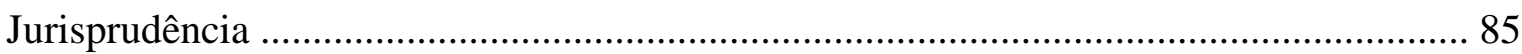

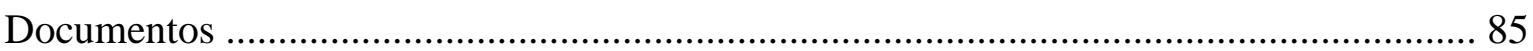

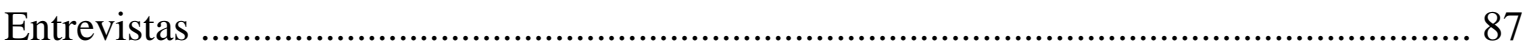

Anexo A - Entrevista com o Professor Mahmoud …........................................................... 89

Anexo B - Entrevista com o Sheikh Davi Munir ............................................................... 95

Anexo C - Entrevista com a Sra. Nadia Ettaouass e o Sr. Islam Reis ................................. 101

Anexo D - Inquérito a professores de escolas públicas de Munique (Alemanha) ............... 107 



\section{Abreviaturas}

Art.: artigo (de lei)

BvR: Bundesverfassungericht (Tribunal Constitucional alemão)

CEDH: Convenção Europeia dos Direitos do Homem

Cfr.: confrontar

cit.: citado

Dep. Legal: Depósito legal

ed.: edição

ISBN: International Standard Book Number

no: número

p.: página

sec.: secção

Sr.: senhor

Sra.: senhora

TC: Tribunal Constitucional

TEDH: Tribunal Europeu dos Direitos do Homem

UE: União Europeia

v.: versus

Vol.: volume

Nota 1: Todas as citações feitas a partir do alemão, do espanhol, do francês, do inglês e do italiano foram traduzidas pela autora da dissertação.

Nota 2: As entrevistas que compõem os anexos desta dissertação consistem em transcrições literais dos áudios gravados in loco, durante as conversas com os entrevistados, respeitando a linguagem dos mesmos. 


\section{Introdução}

Todos os seres humanos nascem livres e iguais em dignidade e em direitos. Dotados de razão e de consciência, devem agir uns para com os outros em espírito de fraternidade.

(Art. $1^{\circ}$ da Declaração Universal dos Direitos do Homem)

Este trabalho pretende analisar criticamente a decisão proferida no acórdão do Tribunal Constitucional alemão (em BvR 471/10 e BvR 1181/10), em 27 de janeiro de 2015, sobre a proibição geral do uso do véu islâmico pelas professoras das escolas públicas na Alemanha, sob a ótica da constitucionalidade da restrição de direitos fundamentais, em particular, do direito ao uso de símbolos religiosos pelas mesmas professoras, expressão da sua liberdade de manifestação de crenças, com base num risco abstrato da violação de outros direitos e princípios, no âmbito do ordenamento jurídico alemão.

Para o efeito, este estudo encontra-se divido em quatro Capítulos, que buscam percorrer, criticamente, o caminho trilhado pelo Tribunal Constitucional alemão até chegar à solução da lide.

O primeiro Capítulo tem a finalidade de identificar o que é o véu islâmico, objeto em discussão no julgado, e qual a sua importância para a religião muçulmana, separando os conceitos de símbolo religioso e de código religioso, bem como a dimensão de ambos dentro de uma determinada confissão. Especialmente para conhecer a realidade subjacente a este Capítulo, foram feitas entrevistas a um líder religioso islâmico, em Portugal, e a seguidores do islamismo, residentes neste País, tanto do sexo feminino como do sexo masculino.

Para além do significado do véu e da sua relevância para a confissão islâmica, mister se fez averiguar do significado pessoal do seu uso para as mulheres muçulmanas. Que importância tem o uso do véu para as mulheres que optam por envergá-lo? Que efeitos surte tal indumentária na sociedade ocidental?

O segundo Capítulo faz uma apresentação sintética do Acórdão do Tribunal Constitucional alemão (BvR 471/10 e BvR 1181/10), cuja decisão, objeto deste estudo, considerou que uma proibição geral do uso do véu por professoras das escolas públicas não é compatível com a Constituição. Nesta narrativa, será feito um paralelo com julgado do ano de 2003, onde o mesmo Tribunal Constitucional julgou questão idêntica à de 2015, porém, em sentido contrário. 
O terceiro Capítulo, divido em quatro alíneas, destina-se a mostrar as diferenças de entendimento da expressão "neutralidade do Estado" e de como isso afeta a liberdade religiosa, a partir de dois exemplos práticos de casos julgados. Foram escolhidos um caso do Tribunal Constitucional português e um caso do Tribunal Europeu dos Direitos do Homem, ambos relacionados com a religião e o ensino público, por serem as sentenças mais relevantes e recentes proferidas por dois tribunais superiores com jurisdição no ordenamento jurídico português e com o objeto mais próximo ao do acórdão alemão em foco.

Inicialmente, a "Introdução" faz uma breve abordagem sobre o direito fundamental à liberdade religiosa e sobre o papel do Estado em relação a esse direito, visando introduzir o ponto central de análise do Capítulo, qual seja, a questão da neutralidade do Estado.

Na alínea “a”, é abordado o acórdão no 174/93, de 17 de fevereiro de 1993, do Tribunal Constitucional português, onde foi julgada e confirmada a não inconstitucionalidade da lecionação da disciplina de ensino da Religião e Moral Católicas, nas escolas públicas de Portugal, pelos próprios professores do ensino primário.

Na alínea "b”, analisa-se o acórdão Dahlab v. Suíça, de 15 de fevereiro de 2001, do Tribunal Europeu dos Direitos do Homem, no qual o referido tribunal confirmou a decisão do Tribunal Federal suíço, que manteve a demissão de uma professora de uma escola pública, devido ao uso do véu islâmico.

Na alínea "c", faz-se um paralelo entre os conceitos de neutralidade estatal adotados em Portugal e na Suíça e os respetivos reflexos no exercício da liberdade religiosa.

Entrando no estudo do sistema alemão, o quarto Capítulo é dedicado à abordagem da liberdade religiosa na Alemanha, sendo dividido em quatro alíneas, que tratam, individualmente, dos vários aspetos que envolvem o exercício dessa liberdade fundamental.

Primeiramente, na alínea "a", mostra-se um panorama da sociedade alemã. Com base em dados e pesquisas demográficas oficiais, dá-se uma visão da atual população alemã, tanto nacionais como imigrantes, bem como da percentagem de seguidores do islamismo.

Buscando uma visão, a mais próxima possível, da realidade alemã perante o objeto deste estudo, qual seja, a utilização do véu islâmico por professoras das escolas públicas, realizou-se um inquérito a professores de escolas públicas da cidade de Munique, apurando-se assim a visão dos mesmos em relação à religião e à sua vivência na escola.

A alínea "b" trata das relações Igreja-Estado na Alemanha. Passando por uma breve introdução histórica, chega-se ao atual sistema de cooperação, para estudar o estatuto do islamismo dentro desse sistema. 
Prosseguindo, a alínea "c" trata da Lei Fundamental da Alemanha, da sua Constituição, guardiã dos direitos, liberdades e garantias. Aqui, faz-se uma análise das normas de interpretação da Constituição e das leis ordinárias aplicáveis, com destaque para o "princípio da interpretação conforme a Constituição”, e explica-se também o regime das restrições aos direitos fundamentais constitucionalmente protegidos.

Finalizando o Capítulo quarto, a alínea "d” faz uma análise crítica da decisão proferida no acórdão do Tribunal Constitucional alemão (BvR 471/10 e BvR 1181/10), em 27 de janeiro de 2015, nomeadamente, da aplicação do princípio da interpretação conforme a Constituição e, ainda, da influência do risco concreto e do risco abstrato na restrição a direitos fundamentais.

Encerra-se este trabalho com conclusões sobre o direito ao uso de símbolos religiosos pelas professoras das escolas públicas, expressão da sua liberdade de manifestação de crenças, enquanto direito fundamental, e seu papel na formação de uma sociedade democrática, num Estado de Direito.

$\mathrm{Na}$ busca por uma resposta que concilie os deveres do Estado e os direitos dos indivíduos, de forma justa e harmoniosa, foram pesquisadas e comparadas, ao longo de todo o trabalho, teorias sobre a relação Igreja-Estado e sobre até onde o Estado pode interferir na liberdade religiosa dos cidadãos.

Tendo em vista o acórdão em foco, uma especial atenção é dada à questão da presença muçulmana na Europa da atualidade, sem que isso implique, entretanto, fazer uma defesa proselitista do islamismo ou de qualquer outra confissão religiosa.

Vários Países da Europa veem utilizando as restrições à liberdade religiosa como forma de proteção contra os crescentes ataques terroristas. Será que este é o melhor ou mais eficaz caminho para a paz? Onde fica o respeito à diversidade, numa sociedade pluralizada e aterrorizada?

Iniciado por uma pergunta, este estudo pretende encerrar-se com um esclarecimento que faça jus à grandeza daquela que é a mãe de todas as liberdades: a liberdade religiosa. 


\section{Capítulo I - O véu islâmico: código de vestuário ou símbolo religioso?}

O véu consiste numa peça de tecido que já fazia parte das vestimentas dos povos árabes, mesmo antes do surgimento do islamismo.

No mundo muçulmano, são apresentados cinco modelos diferentes de véu (Figura 1), cujo uso varia de acordo com a região e a escola de pensamento islâmico.

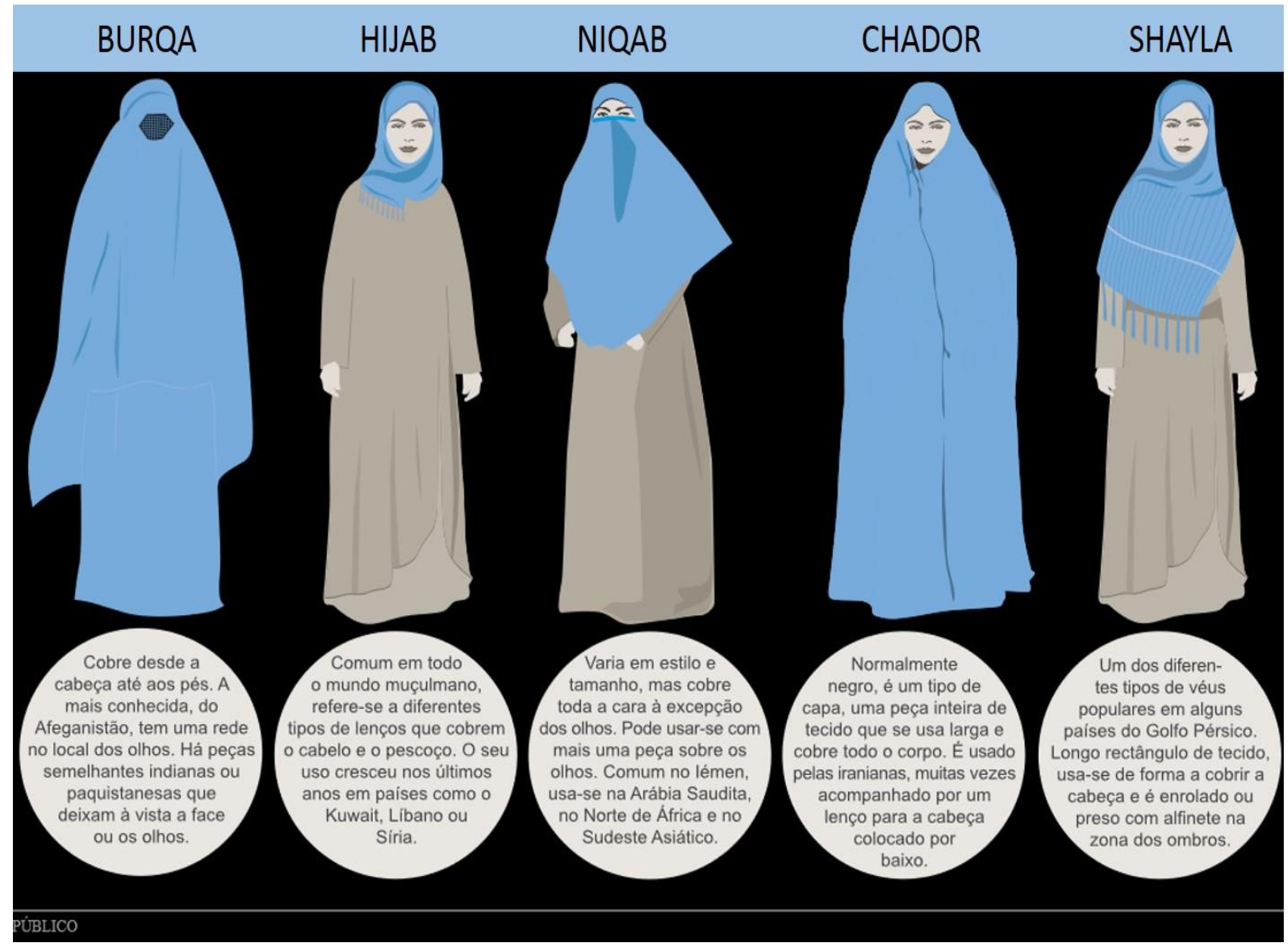

Figura 1.

Fonte: Jornal Público ${ }^{1}$

Em conversa ${ }^{2}$ com o Professor Mahmoud ${ }^{3}$, no Centro Cultural Islâmico do Porto, este esclareceu que a grande diferença entre os tipos de véu está ligada à cultura onde cada um surgiu e exemplificou com a história da origem da burqa.

\footnotetext{
${ }^{1}$ LORENA, Sofia - Decisão da justiça sobre véu vai "banir muçulmanas do mercado de trabalho". Jornal Público. 14 Mar. 2017. [Em linha]. [Consultado em 05-04-2017]. Disponível em

https://www.publico.pt/2017/03/14/mundo/noticia/decisao-da-justica-europeia-sobre-o-veu-abre-porta-adiscriminacoes-1765207.

${ }^{2}$ Entrevista realizada às 11 h00 do dia 3 de novembro de 2017, no Centro Cultural Islâmico do Porto. Para aprofundamento, consultar entrevista em anexo.

${ }^{3}$ O Professor Mahmoud é membro ativo da Comunidade Islâmica do Porto.
} 
Contou o Professor Mahmoud que, conforme vários registos históricos, a burqa nem sequer teria surgido no mundo islâmico. Há, sobretudo, dois registos que explicam o seu surgimento. Um deles diz respeito a uma comunidade que teria vivido na zona do Iêmen, muito antes do Islão, e que cultuava uma deusa da fertilidade, a deusa Iris. Parte do grupo de mulheres que cultuavam essa deusa era de prostitutas; então, para não serem estigmatizadas pelo resto da comunidade, as seguidoras da deusa cobriam todo o corpo, assim, as pessoas não podiam reconhecer quem eram as praticantes do culto. Este é um dos registos.

O outro registo diz respeito a uma comunidade que teria existido na zona de Palmira e fazia parte da civilização suméria. Tal comunidade também cultuava um deus pagão, o deus Bel, e as mulheres usavam um tipo de vestimenta semelhante à burqa. Com o nascimento do Islão, tais trajes, assim como outros que já estavam integrados nessas culturas, passaram a fazer parte do vestuário islâmico.

O Professor Mahmoud esclareceu, ainda, que o Islão não impõe o uso de determinado modelo de véu, seja a burqa, o niqab, a shayla, o chador ou o hijab. O Alcorão, livro sagrado do Islão, apenas preceitua dever a mulher cobrir-se, sendo o hijab o modelo mais comum no mundo islâmico: "Ó Profeta, dize a tuas esposas, às tuas filhas e às mulheres dos fiéis que (quando saírem) se cubram com as suas mantas; isso é mais conveniente, para que se distingam das demais e não sejam molestadas; sabei que Deus é Indulgente, Misericordiosíssimo" (Alcorão, 33:59). Porém, é de salientar que, em alguns Países, cujo governo é confessional, como a Arábia Saudita e o Irão, o uso do véu é obrigatório por lei e o incumprimento da norma gera penalidades para as mulheres. Quanto a isto, o referido Professor fez questão de ressaltar que esse tipo de obrigatoriedade vem do Estado e não da religião.

Neste ponto colocamos a seguinte questão: Será o véu, independentemente do modelo, um código de vestuário ou um símbolo religioso islâmico?

Vejamos, primeiramente, os significados das palavras código e símbolo. Segundo o Dicionário da Língua Portuguesa Contemporânea da Academia das Ciências de Lisboa ${ }^{4}$, a palavra "código", em sentido amplo, é um substantivo masculino, destinado a designar um conjunto de regras, convenções, preceitos, leis, etc., sobre qualquer matéria (5 Vols., I, p. 855856); é corrente, aliás, a expressão inglesa dress code, para designar um código de vestuário. Já o vocábulo "símbolo" é definido como um substantivo masculino que, entre outras destinações, tem o intuito de ser o formulário ou credo que contém os principais artigos da fé

\footnotetext{
${ }^{4}$ Dicionário da Língua Portuguesa Contemporânea da Academia das Ciências de Lisboa. Volumes I-II. Academia das Ciências de Lisboa e Editorial Verbo. 2001. Dep. legal no 161290/01.
} 
de uma religião, e, especificamente, no sentido teológico, trata-se de uma manifestação visível da ligação entre uma pessoa e uma religião (5 Vols., II, p. 3415) .

Existe uma grande discussão sobre o véu ser ou não um símbolo religioso, protagonizada por filósofos, juristas, sociólogos, intelectuais, em geral, bem como a imprensa. Todavia, acreditamos ser válida a definição dada pelo próprio Islão, pois cabe apenas a cada confissão definir quais são os seus símbolos. O Sheikh Davi Munir, Imã ${ }^{6}$ da Mesquita Central de Lisboa, questionado ${ }^{7}$ sobre a matéria, foi categórico ao dizer que o véu não é um símbolo religioso, pois o Islão não possui símbolos.

Conforme explica o Sheikh Munir, o véu, isto é, o gesto de cobrir a cabeça e o cabelo, é um preceito do vestuário de uma muçulmana, segundo o Alcorão, e não deve ser considerado como um símbolo. Por ser um mandamento corânico, nem sequer é possível refutá-lo ou discutilo, mas, considerar o véu um símbolo é um erro.

Além das perguntas sobre o véu ser ou não um símbolo religioso, um ponto muito discutido na atualidade e que, entre outros, está a servir de argumento para as crescentes restrições ao uso do véu islâmico em espaços públicos, em alguns Países europeus, é a relação que se estabelece entre o véu e a inferiorização das mulheres perante os homens.

Relativamente a essa suposta inferiorização, o Sheikh Munir e o Professor Mahmoud esclarecem que o objetivo do véu é tão somente o de proteger a mulher. Segundo os entrevistados, o Islão não discrimina a mulher e, tal como as mulheres, os homens também possuem um código de vestuário que deve ser seguido, tanto quanto outros códigos, tais como o código alimentar e o código de conduta.

Conversamos ainda com Nadia Ettaouass ${ }^{8}$, uma senhora marroquina, muçulmana de nascimento, que se casou com um português e se mudou para Portugal, na tentativa de conhecer a visão pessoal de quem vivencia o conflito de utilizar ou não véu, no Ocidente. Segundo a Sra.

\footnotetext{
${ }^{5}$ O Dicionário citado especifica outros significados da palavra símbolo: "Ser, objecto ou facto que representa uma realidade abstracta; signo concreto de valor abstracto. $\approx$ ATRIBUTO, REPRESENTAÇÃO. O cordeiro é um símbolo da inocência. Ser objecto ou imagem a que se convencionou atribuir determinado significado. Rel. Sinal particular com que se reconhecem os iniciados num culto. O peixe é um símbolo dos primeiros cristãos. Rel. Objecto ou imagem com poder evocador, mágico, místico. Rel. Formulário que contém os dogmas fundamentais do cristianismo. O símbolo dos Apóstolos. O símbolo de Niceia".

${ }^{6}$ Imã, Imam ou Imame: oficialmente é o título do sucessor do Profeta Mohammad e líder da nação, igualmente um título dado aos principais líderes islâmicos, ou também ao Sheikh ou a pessoa que lidera a reza. Cfr. ARBIB - Associação Religiosa Beneficente Islâmica do Brasil. [em linha]. [Consultado em 12 de abril de 2018]. Disponível em http://www.mesquitadobras.org.br/dic.php?op=26\&cod=71.

${ }^{7}$ Entrevista realizada às 14 h30 do dia 15 de novembro de 2017, na Mesquita Central de Lisboa. Para aprofundamento, consultar entrevista em anexo.

${ }^{8}$ Entrevista realizada às $12 \mathrm{~h} 00$ do dia 28 de dezembro de 2017, na cidade do Porto. Para aprofundamento, consultar entrevista em anexo.
} 
Nadia, o uso do véu nunca a fez sentir-se inferior aos homens; pelo contrário, em Marrocos, as mulheres que usam o véu são tratadas com maior deferência. Entretanto, foi com pesar que a entrevistada relatou vários casos de atitudes pejorativas contra a sua fé, conotada pelo uso do véu, sofridos na cidade do Porto, ao mudar-se para Portugal. Para evitar maiores desgastes, a Sra. Nadia optou por deixar de usar o hijab ${ }^{9}$.

Na presença do seu marido, o Sr. Islam Reis, português que se converteu ao islamismo, a Sra. Nadia exprimiu o seu desejo de voltar a usar o véu e viver a sua fé plenamente, bem como a tristeza que sente por não estar a cumprir um preceito do Alcorão.

Por sua vez, o Sr. Islam ressaltou que o uso do véu é um dever religioso e que a mulher, como qualquer fiel que quer agradar a Deus em toda a plenitude da sua crença, sente-se muito triste por não poder fazê-lo.

Na defesa do uso do véu islâmico, outro ponto relevante, lembrado tanto pelo Professor Mahmoud como pelo Sheikh Munir, é o fato de o véu não ser exclusivo do Islão. Também outras confissões utilizam o véu como parte do seu vestuário, nomeadamente as freiras católicas, cujo hábito religioso integra um véu.

Pelo contrário, o então Presidente da França, Nicolas Sarkozy, pronunciando-se sobre esta matéria, em 2009, declarou que o uso do véu não é um sinal religioso, mas sim um sinal de subserviência da mulher ao homem e que tal atitude não era bem-vinda em França ${ }^{10}$.

Rebatendo argumentos como o de Sarkozy, o reconhecido filósofo búlgaro, radicado em França, Tzvetan Todorov (2012, p. 172), esclarece que: “A primeira proibição [Lei de 2010 que proibiu o uso da burqa em qualquer espaço público, inclusive nas ruas e lojas] se baseia em vários argumentos. Um deles é que o véu integral é um sinal de alienação; portanto, ao removêlo, as mulheres que o usam seriam libertadas. Ao que parece, não se percebe o caráter intrinsecamente contraditório dessa suposição: como é possível favorecer a liberdade individual punindo com uma sanção aquilo que resulta da livre escolha de um indivíduo? Sem dúvida, pode-se lamentar a existência de tais práticas; mas, combatendo-as pela coação, diminui-se a liberdade daquelas que as escolhem, em vez de ampliá-la. Exceto se considerarmos que certas pessoas não merecem gerir por conta própria suas vidas, mas sim, como as crianças menores,

\footnotetext{
${ }^{9}$ Sobre a liberdade religiosa em Portugal, falaremos mais apropriadamente no Capítulo III.

${ }^{10}$ Cfr. BBC notícias. [em linha]. [Consultado em 14 de fevereiro de 2018]. Disponível em http://www.bbc.com/portuguese/noticias/2009/06/090622_sarkozyburca_np.
} 
os doentes mentais ou os prisioneiros privados de seus direitos civis, devem subordinar-se às decisões dos outros"11.

Relativamente à suposta proteção da dignidade e liberdade das mulheres muçulmanas, que alguns Estados insistem em defender, Patrícia Jerónimo (2010, p. 501-502) pronunciou-se sobre os casos Leila Sahin v. Turquia ${ }^{12}$ e Dogru v. França ${ }^{13}$, julgados pelo TEDH, nos quais se discutia a proibição de algumas estudantes usarem o véu nas escolas públicas, excluindo-as, em consequência, da frequência escolar: "No seu imenso paternalismo, o Tribunal decidiu o que é melhor para as mulheres muçulmanas e propôs libertá-las das peias que o véu representa. Fê-lo conferindo legitimidade a práticas estaduais que, não apenas restringem a liberdade religiosa dessas mulheres, como ainda as privam daquela que é a melhor forma de aceder à emancipação, na medida em que comprometem muito seriamente o seu direito à instrução" ${ }^{" 14}$.

Em conclusão, com base nos preceitos islâmicos ditados no seio de sua liberdade de autoorganização, podemos responder à questão que dá o título a este Capítulo, "O véu islâmico: código de vestuário ou símbolo religioso?”, afirmando que o véu islâmico não é um símbolo religioso, mas sim um código de vestuário islâmico. Por outras palavras, salientamos que é à dinâmica interna das confissões religiosas que cabe a definição do seu próprio pensamento sobre o "ser" e do "dever ser", diga-se, quanto aos seus códigos: essa é uma expressão da sua liberdade que é protegida nas sociedades livres e democráticas. Cabe ao Estado proteger o pluralismo, garantindo a liberdade de cada uma dessas confissões. "Assim entendida, a normativa jurídica do Estado adquire também uma dimensão ética que lhe é funcional, isto é, proveniente da sua própria 'função' de serviço à sociedade"15(Setién [et al], 2008, p. 51).

\footnotetext{
${ }^{11}$ Cfr. TODOROV, Tzvetan - Os inimigos íntimos da democracia. (Les ennemis intimes de la démocratie). Tradução: Joana Angélica d'Avila Melo. São Paulo. Companhia das Letras, 2012. ISBN 978-85-359-2142-7. p. 172.

${ }^{12} \mathrm{O}$ teor integral do acórdão está disponível em https://hudoc.echr.coe.int/eng\#\{\%22itemid\%22:[\%220031503367-1572572\%22]\}. [Consultado em 2 de março de 2018].

${ }^{13} \mathrm{O}$ teor integral do acórdão está disponível em https://hudoc.echr.coe.int/eng\#\{\%22fulltext\%22:[\%22dogru\%22],\%22languageisocode\%22:[\%22ENG\%22],\%2 2documentcollectionid2\%22:[\%22GRANDCHAMBER\%22,\%22CHAMBER\%22],\%22kpdate\%22:[\%22200801-01T00:00:00.0Z\%22,\%222008-12-31T00:00:00.0Z\%22],\%22itemid\%22:[\%22001-90039\%22]\}.

[Consultado em 2 de março de 2018].

${ }^{14}$ Cfr. JERÓNIMO, Patrícia - Símbolos e símbolos - o véu islâmico e o crucifixo na jurisprudência recente do Tribunal Europeu dos Direitos do Homem: Análise das decisões Sahin v. Turquia, Dogru v. França e Lautsi v. Itália, in Scientia Juridica, Tomo LIX, no 323 (2010). p. 501-502.

${ }^{15}$ SETIÉN ALBERRO, José Maria; POLICARPO, José (co-autor) - Laicidade e Laicismo - Igreja, Estado e Sociedade (Laicidad del Estado y Iglesia). Tradução: Margarida Osório Gonçalves. Coimbra. Gráfica de Coimbra 2, 2008. ISBN 978-972-603-424-7. p. 51.
} 


\section{Capítulo II - O Acórdão do Tribunal Constitucional alemão (BvR 471/10 e BvR 1181/10), de 27 de janeiro de 2015 - apresentação do caso ${ }^{16}$}

O acórdão em foco trata dos casos de duas profissionais da educação, muçulmanas, de nacionalidade alemã, ambos ocorridos no Estado da Renânia do Norte-Vestfália ${ }^{17}$, cujos processos, BvR 471/10 e BvR 1181/10, foram conjuntamente julgados, no dia 27 de janeiro de 2015, pelo Tribunal Constitucional alemão. Deu-se assim a junção de dois processos, quando julgados por este tribunal superior.

Nos dois casos, a autoridade da Administração escolar, com base na Lei Educacional do Estado da Renânia do Norte-Vestfália, recriminou e penalizou as profissionais pelo facto das mesmas cobrirem os seus cabelos, conforme preceitua a religião muçulmana, alegando um risco abstrato à paz na escola e à liberdade religiosa de pais e alunos.

A autoridade escolar justificou a pena imposta às profissionais, invocando o $§ 57$, secção 4, sentenças 1, 2 e 3, e o $\$ 58$, sentença 2, da Lei Educacional promulgada em 15 de fevereiro de 2005, com as alterações realizadas em 13 de junho de 2006.

A norma invocada defendia, no 557 , sec. 4, sentença 1, que os professores não poderiam, publicamente, expressar pontos de vista políticos, religiosos, ideológicos ou similares que pudessem interferir ou pôr em causa a neutralidade do Estado, bem como a liberdade religiosa de pais e alunos, ou perturbar a paz política, religiosa e ideológica na escola. No §57, sec. 4, sentença 2, dizia que era proibido adotar uma conduta capaz de criar a impressão, entre pais e alunos, de o professor estar a fazer apologia contra a dignidade humana, a igualdade de tratamento, as liberdades fundamentais ou a liberdade democrática. Enquanto o §57, sec. 4, sentença 3, declarava que expressar tradições educacionais e culturais cristãs e ocidentais não contrariava o disposto na sentença 1. Por último, o $\$ 58$, sentença 2 , expunha que estas disposições aplicavam-se aos demais funcionários da educação, incluindo o pessoal socioeducativo, empregado pelo Estado.

No primeiro caso, qual seja, BvR 471/10, a demandante era funcionária de uma escola estatal, na condição de assistente social, desde 1997. Com a entrada em vigor da Lei Educacional, em 2005, ao ser solicitada, pela autoridade escolar, a deixar de usar o véu islâmico (hijab), a profissional atendeu ao pedido, porém, em substituição, passou a cobrir-se com uma

\footnotetext{
${ }^{16} \mathrm{O}$ teor integral do acórdão está disponível em http://www.bverfg.de/e/rs20150127_1bvr047110en.html (original em alemão e versão traduzida para o inglês). [Consultado em 30 de março de 2017].

${ }^{17}$ Todos os nomes de cidades e estados, ao longo deste trabalho, foram traduzidos para o português.
} 
boina cor-de-rosa e uma faixa de malha nos cabelos, e com uma espécie de cachecol no pescoço. Em vista disso, a autoridade escolar emitiu uma advertência à educadora que, por sua vez, intentou uma ação contra o Estado da Renânia do Norte-Vestfália perante o Tribunal do Trabalho, tendo o seu pedido sido denegado em todas as instâncias.

O processo BvR 1181/10 foi movido pela segunda demandante que, em 2001, celebrou um contrato privado de trabalho com o Estado da Renânia do Norte-Vestfália, para ensinar o idioma turco a falantes nativos, em várias escolas. Assim como procedeu com a primeira demandante, a autoridade escolar solicitou que a professora deixasse de usar o véu islâmico (hijab), estando a nova Lei Educacional em vigor, e, diante da recusa da mesma em atender ao pedido, emitiu uma advertência e, em seguida, demitiu-a. A professora intentou uma ação junto da Justiça Laboral; porém, não obteve êxito e a sua demissão foi mantida.

Assim, as demandantes dirigiram ao Tribunal Constitucional alemão as suas queixas contra as decisões dos Tribunais do Trabalho, diretamente, e contra as disposições da Lei Educacional do Estado da Renânia do Norte-Vestfália, indiretamente, alegando violação dos seus direitos, protegidos tanto pela Lei Fundamental da Alemanha, quanto pela Convenção Europeia dos Direitos do Homem.

Conforme alegado pelas profissionais da educação, foram violados os seus direitos à liberdade religiosa e ao exercício geral de personalidade, enquanto nacionais alemãs, todos garantidos pelos dispositivos previstos nos artigos $1^{\circ}, 2^{\circ}, 3^{\circ}, 4^{\circ}, 12^{\circ}$ e $33^{\circ}$ da Lei Fundamental da Alemanha ${ }^{18}$, que salvaguardam, respectivamente, a dignidade da pessoa humana, o livre

\footnotetext{
18 “Artigo $1^{\circ}$ [Dignidade da pessoa humana - Direitos humanos - Vinculação jurídica dos direitos fundamentais]

(1) A dignidade da pessoa humana é intangível. Respeitá-la e protegê-la é obrigação de todo o poder público.

(...)

Artigo $2^{\circ}$ [Direitos de liberdade]

(1) Todos têm o direito ao livre desenvolvimento da sua personalidade, desde que não violem os direitos de outros e não atentem contra a ordem constitucional ou a lei moral.

(...)

Artigo $3^{\circ}$ [Igualdade perante a lei]

(1) Todas as pessoas são iguais perante a lei.

(...)

(3) Ninguém poderá ser prejudicado ou favorecido por causa do seu sexo, da sua descendência, da sua raça, do seu idioma, da sua pátria e origem, da sua crença ou das suas convicções religiosas ou políticas. Ninguém poderá ser prejudicado por causa da sua deficiência.

Artigo $4^{\circ}$ [Liberdade de crença e de consciência]

(1) A liberdade de crença, de consciência e a liberdade de confissão religiosa e ideológica são invioláveis.

(2) É assegurado o livre exercício da religião.

(...)

Artigo $12^{\circ}$ [Liberdade de escolha da profissão]

(1) Todos os alemães têm o direito de escolher livremente a sua profissão, o lugar de trabalho e o de aprendizagem. O exercício da profissão pode ser regulamentado por lei ou em virtude de lei.

(...)
} 
desenvolvimento da personalidade, a igualdade de todos perante a lei, a liberdade de crença e exercício da religião, a livre escolha da profissão e a igualdade de acesso a cargos públicos.

Além da proteção constitucional, as demandantes invocaram também a Convenção Europeia dos Direitos do Homem, que, nos seus artigos $9^{\circ}$ e $14^{\circ}$, protege a liberdade religiosa e garante a proibição de discriminação ${ }^{19}$.

Após uma minuciosa análise, utilizando, principalmente, o princípio da interpretação conforme à Constituição, o Tribunal decidiu a favor das demandantes, determinando a reversão das decisões dos Tribunais do Trabalho, a interpretação conforme a Constituição do §57, secção 4, sentenças 1 e 2, da Lei Educacional do Estado da Renânia do Norte-Vestfália, bem como a inconstitucionalidade da sentença 3, da secção 4, do $\$ 57$ desta mesma Lei Educacional ${ }^{20}$.

Artigo $33^{\circ}$ [Igualdade de direitos cívicos dos alemães - Serviço público]

(...)

(2) Todos os alemães têm igual acesso a qualquer cargo público, de acordo com sua aptidão, capacidade $e$ desempenho profissional.

(3) O gozo dos direitos civis e cívicos, a admissão a cargos públicos, bem como os direitos adquiridos no serviço público são independentes da confissão religiosa. Ninguém poderá sofrer discriminação por professar ou deixar de professar determinada religião ou ideologia".

Cfr. Todos os excertos da Lei Fundamental da Alemanha, utilizados neste trabalho, são provenientes da versão traduzida para o português, disponível no sítio oficial Deutscher Bundestag. [em linha]. [Consultado em 26 de abril de 2018]. Disponível em https://www.btg-bestellservice.de/pdf/80208000.pdf.

19 “Artigo $9^{\circ}$ [Liberdade de pensamento, de consciência e de religião]

1. Qualquer pessoa tem direito à liberdade de pensamento, de consciência e de religião; este direito implica a liberdade de mudar de religião ou de crença, assim como a liberdade de manifestar a sua religião ou a sua crença, individual ou coletivamente, em público e em privado, por meio do culto, do ensino, de práticas e da celebração de ritos.

2. A liberdade de manifestar a sua religião ou convicções, individual ou coletivamente, não pode ser objeto de outras restrições senão as que, previstas na lei, constituírem disposições necessárias, numa sociedade democrática, à segurança pública, à proteção da ordem, da saúde e moral públicas, ou à proteção dos direitos e liberdades de outrem.

Artigo $14^{\circ}$ [Proibição de discriminação]

O gozo dos direitos e liberdades reconhecidos na presente Convenção deve ser assegurado sem quaisquer distinções, tais como as fundadas no sexo, raça, cor, língua, religião, opiniões políticas ou outras, a origem nacional ou social, a pertença a uma minoria nacional, a riqueza, o nascimento ou qualquer outra situação”. Cfr. Convenção Europeia dos Direitos do Homem. [em linha]. [Consultado em 26 de abril de 2018]. Disponível em https://www.echr.coe.int/Documents/Convention_POR.pdf.

${ }^{20}$ Cfr., no original, acórdão do Tribunal Constitucional alemão (BvR 471/10 e BvR 1181/10), de 27 de janeiro de 2015. [em linha]. [Consultado em 30 de março de 2017]. Disponível em http://www.bundesverfassungsgericht.de/SharedDocs/Entscheidungen/DE/2015/01/rs20150127_1bvr047110.ht ml: “[...] hat das Bundesverfassungsgericht - Erster Senat - unter Mitwirkung der Richterinnen und Richter Gaier, Eichberger, Schluckebier, Masing, Paulus, Hermanns, Baer, Britz, am 27. Januar 2015 beschlossen: 1. $\$ 57$ Absatz 4 Satz 3 des Schulgesetzes für das Land Nordrhein-Westfalen vom 15. Februar 2005 (Gesetz-und Verordnungsblatt für das Land Nordrhein-Westfalen Seite 102) in der Fassung des Ersten Gesetzes zur Änderung des Schulgesetzes für das Land Nordrhein-Westfalen vom 13. Juni 2006 (Gesetz- und Verordnungsblatt für das Land Nordrhein-Westfalen Seite 270) ist mit Artikel 3 Absatz 3 Satz 1 und mit Artikel 33 Absatz 3 des Grundgesetzes unvereinbar und nichtig.

2. $\$ 57$ Absatz 4 Sätze 1 und 2 sowie \$58 Satz 2 des vorbezeichneten Gesetzes sind, soweit sie religiöse Bekundungen durch das äußere Erscheinungsbild betreffen, nach Maßgabe der Gründe mit dem Grundgesetz. vereinbar.

3. Die Beschwerdeführerin zu I.) wird durch das Urteil des Bundesarbeitsgerichts vom 20. August 2009 - 2 AZR 499/08 -, das Urteil des Landesarbeitsgerichts Düsseldorf vom 10. April 2008 - 5 Sa 1836/07 - und das Urteil 
O Tribunal Constitucional ressaltou, ainda, que um mero risco abstrato para a paz na escola e para a liberdade religiosa de pais e alunos não pode servir de base para restringir o direito à liberdade religiosa dos professores e demais profissionais da educação, mas apenas um evidente risco concreto justificaria uma restrição como esta ${ }^{21}$.

Ressalta-se que a Lei Educacional da Renânia do Norte-Vestfália só foi promulgada graças a uma decisão anterior do próprio Tribunal Constitucional alemão que, em 24 de setembro de 2003, julgou o caso de Fereshta Ludin (BvR 1436/02) ${ }^{22}$, uma senhora muçulmana, nascida no Afeganistão e naturalizada alemã, por motivos idênticos aos dois casos de 2015. A Senhora Ludin interpôs uma ação perante o referido Tribunal por não ter sido admitida ao cargo de professora numa escola pública de Estugarda, no Estado de Bade-Vurtemberga, após a sua aprovação em concurso, pelo facto de usar o hijab, sob a mesma alegação de risco abstrato à paz na escola e à liberdade religiosa de pais e alunos.

Em 2003, o Tribunal Constitucional deu ganho de causa à professora, justificando que o Estado de Bade-Vurtemberga não possuía legislação a respeito da utilização de símbolos religiosos pelos professores e que, por esse motivo, não poderia negar a admissão da profissional $^{23}$. Indo ainda mais longe, o TC entendeu que a liberdade religiosa negativa de pais

des Arbeitsgerichts Düsseldorf vom 29. Juni 2007 - 12 Ca 175/07 - in ihrem Grundrecht aus Artikel 4 Absatz 1 und 2 des Grundgesetzes verletzt. Die Urteile des Bundesarbeitsgerichts und des Landesarbeitsgerichts werden aufgehoben. Die Sache wird an das Landesarbeitsgericht Düsseldorf zurückverwiesen.

4. Die Beschwerdeführerin zu II.) wird durch das Urteil des Bundesarbeitsgerichts vom 10. Dezember $2009-2$ AZR 55/09 -, die Urteile des Landesarbeitsgerichts Hamm vom 16. Oktober 2008 - 11 Sa 572/08 - und - 11 Sa 280/08 - sowie die Urteile des Arbeitsgerichts Herne vom 21. Februar 2008 - 6 Ca 649/07 - und vom 7. März 2007 - 4 Ca 3415/06 - in ihrem Grundrecht aus Artikel 4 Absatz 1 und 2 des Grundgesetzes verletzt. Die Urteile des Bundesarbeitsgerichts und des Landesarbeitsgerichts werden aufgehoben. Die Sache wird an das Landesarbeitsgericht Hamm zurückverwiesen.

5. Das Land Nordrhein-Westfalen hat den Beschwerdeführerinnen jeweils drei Viertel, die Bundesrepublik Deutschland jeweils ein Viertel ihrer notwendigen Auslagen zu erstatten".

${ }^{21}$ Cfr., no original, acórdão do Tribunal Constitucional alemão (BvR 471/10 e BvR 1181/10)... cit., §80: “Die in den Ausgangsverfahren ergangenen Urteile der Arbeitsgerichte beruhen auf einer gesetzlichen Grundlage, die der einschränkenden verfassungskonformen Auslegung bedarf. Deren Anforderungen genügen die Urteile nicht. Ein Verbot religiöser Bekundungen durch das äußere Erscheinungsbild, das bereits die abstrakte Gefahr einer Beeinträchtigung des Schulfriedens oder der staatlichen Neutralität ausreichen lässt, ist im Blick auf die Glaubens- und Bekenntnisfreiheit der Pädagogen jedenfalls unangemessen und damit unverhältnismäßig, wenn die Bekundung nachvollziehbar auf ein als verpflichtend empfundenes religiöses Gebot zurückführbar ist. Erforderlich ist vielmehr eine hinreichend konkrete Gefahr. Eine entsprechende gebietsbezogene, möglicherweise auch landesweite Untersagung kommt von Verfassungs wegen für öffentliche bekenntnisoffene Gemeinschaftsschulen nur dann in Betracht, wenn eine hinreichend konkrete Gefahr für die genannten Schutzgüter im gesamten Geltungsbereich der Untersagung besteht”.

${ }^{22}$ Cfr. o teor integral do acórdão do Tribunal Constitucional alemão (BvR 1436/02), de 24 de setembro de 2003 (original em alemão e versão traduzida para o inglês). [em linha]. [Consultado em 26 de abril de 2018]. Disponível em http://www.bverfg.de/e/rs20030924_2bvr143602en.html.

${ }^{23}$ Cfr., no original, acórdão do Tribunal Constitucional alemão (BvR 1436/02)... cit., §72: “Solange keine gesetzliche Grundlage besteht, aus der sich mit hinreichender Bestimmtheit ablesen lässt, dass für Lehrer an Grund- und Hauptschulen eine Dienstpflicht besteht, auf Erkennungsmerkmale ihrer Religionszugehörigkeit in Schule und Unterricht zu verzichten, ist auf der Grundlage des geltenden Rechts die Annahme fehlender Eignung 
e alunos, bem como que o direito dos pais de educarem os seus filhos, sob a égide do artigo $6^{\circ}$, sentença 2, da Lei Fundamental ${ }^{24}$, não poderia ser perturbada pela liberdade religiosa positiva da reclamante, e que a obrigação do Estado de preservar a sua neutralidade limitava o direito da profissional de expressar a sua fé, mas que, em virtude da falta de legislação estadual sobre a utilização de símbolos religiosos, a profissional em questão não poderia ser preterida de assumir o cargo

Note-se que, em 2003, o Tribunal induziu o Estado a legislar proibitivamente, recomendando a edição de uma lei no sentido de restringir o uso de $\operatorname{símbolos~religiosos~}^{25}$ nas escolas, já que esta era a vontade do Estado. Como consequência, o Estado de BadeVurtemberga expediu efetivamente uma lei restritiva da liberdade religiosa, em abril de 2004, que proibiu o uso do véu islâmico pelas professoras nas escolas públicas, mas continuou admitindo que professores tivessem acesso às salas de aula trazendo crucifixos, símbolos judaicos e, quando fosse o caso, o hábito das freiras.

Apesar de ter garantido o livre acesso da professora muçulmana ao cargo em causa, o Tribunal Constitucional, em 2003, não baseou a sua decisão puramente na liberdade religiosa, mas sobretudo na falta de legislação do Estado que proibisse o uso de símbolos religiosos não pertencentes à tradição judaico-cristã.

Como se viu, o Estado da Renânia do Norte-Vestfália apenas seguiu os passos do Estado de Bade-Vurtemberga, no cumprimento da instrução dada pelo Tribunal Constitucional em 2003.

Em 2015, o TC, ao decidir, levando em consideração o direito fundamental à liberdade religiosa e o respeito à pluralidade, submeteu a controle constitucional as consequências do movimento legislativo ocorrido em vários Estados da Alemanha e corrigiu o erro cometido em 2003.

der Beschwerdeführerin mit Art. 33 Abs. 2 in Verbindung mit Art. 4 Abs. 1 und 2 GG und Art. 33 Abs. 3 GG nicht vereinbar".

${ }^{24}$ Cfr. Lei Fundamental da Alemanha... cit.:

"Artigo $6^{\circ}$ [Matrimônio - Família - Filhos]

(...)

(2) A assistência aos filhos e sua educação são o direito natural dos pais e a sua obrigação primordial. Sobre a sua ação vela a comunidade pública.

(...)"

${ }^{25}$ De acordo com o que foi dito no capítulo I, não consideramos o véu islâmico um símbolo religioso. Todavia, os acórdãos estudados, correntemente, referem-se ao véu com a palavra "símbolo". Assim, para manter uma coerência com os julgados, ao longo desta dissertação, utilizaremos a mesma expressão, procurando, sempre que necessário, esclarecer e lembrar que o véu islâmico não é um símbolo religioso, mas sim, um código de vestuário. 
Como será visto em detalhe no Capítulo IV, em 2015, o Tribunal Constitucional alemão amparou a sua decisão nos preceitos constitucionais que protegem a liberdade religiosa e a igualdade entre os cidadãos e considerou que a neutralidade do Estado consiste em garantir o livre exercício da liberdade religiosa positiva a todos, indistintamente. 


\section{Capítulo III - A liberdade religiosa e a neutralidade do Estado em visões diversas, através da jurisprudência}

\section{Introdução}

Entendida como a primeira de todas as liberdades, a liberdade religiosa exprime a faculdade que os indivíduos têm de aderir a uma determinada cosmovisão. Dentro desta liberdade geral, encontram-se as liberdades de crença, de culto, de consciência, de expressão, de escolha da religião, de mudar de religião, de não seguir qualquer religião, de crer, de não crer, de duvidar, de ser ateu.

Como bem resume Paulo Adragão (2002, p. 115), “[...] a primeira afirmação histórica da liberdade religiosa das pessoas e das comunidades se ficou a dever à difusão do cristianismo na antiguidade. Seu pressuposto essencial é a existência de um Deus transcendente ao mundo que fundamenta a subtração do âmbito religioso ao império do chefe político (dualismo). A expressão libertas religionis é aliás forjada por um jurista cristão do século III"26.

Assim, pode-se dizer que, à vista de uma análise ontológica, a liberdade de crer antepõese à liberdade de não crer, mas isto não significa que uma se sobrepõe à outra.

No pensamento jurídico contemporâneo, os direitos fundamentais e, entre estes, a liberdade religiosa, são exigências inerentes à dignidade humana, ou seja, radicam na própria natureza humana ${ }^{27}$. Segundo Jürgen Habermas (2012, p. 51), “a positivação do primeiro direito fundamental [entenda-se: a primeira declaração dos direitos humanos] criou uma obrigação jurídica de concretização dos conteúdos morais superiores, enterrados na memória da humanidade" 28 .

Cabe ao Estado democrático proteger e amparar o exercício dessa liberdade e é dentro desta função do Estado que se situa a neutralidade, assim entendida como o dever do Estado de

\footnotetext{
${ }^{26}$ Cfr. ADRAGÃO, Paulo Pulido - A Liberdade Religiosa e o Estado. Coimbra. Almedina, 2002. ISBN $972-$ 40-1767-2. p. 115.

${ }^{27}$ Esta ideia foi retirada do texto original: "De ahí que haya podido decirse, con toda razón, que el iusnaturalismo es la verdadera 'ratio communis', el único sistema jurídico que puede ofrecer a tales derechos una base común y estable para su reconocimiento y correcta aplicación. En efecto, sólo la existencia de un Derecho natural, universal, superior y previo a cualquier sistema de Derecho positivo, puede dar razón de esa consciencia jurídica común que impulsa y alienta el movimiento en favor de los derechos humanos. Y entre ellos, el de libertad religiosa", in ORTIZ, Javier Ferrer (coordenador); FORNÉS, Juan; DEL VALLE, José María G.; LOMBARDÍA, Pedro; ALARCÓN, Mariano L.; NAVARRO-VALLS, Rafael; VILADRICH, PedroJuan - Derecho Eclesiástico del Estado Español. $6^{a}$ ed. Pamplona. EUNSA, 2007. ISBN 978-84-313-2496-4. p. 49.

${ }^{28}$ HABERMAS, Jürgen - Um ensaio sobre a Constituição da Europa. Tradução: Marian Toldy e Teresa Toldy. Lisboa. Edições 70, 2012. ISBN 978-972-44-1700-4. p. 51.
} 
não privilegiar o exercício de uma confissão sobre a outra, bem como de não atrapalhar a prática ou a não prática de qualquer religião, mas, pelo contrário, de colaborar com as diversas confissões igualitariamente.

Neste Capítulo, a partir da análise de um acórdão do Tribunal Constitucional português e de um acórdão do Tribunal Europeu dos Direitos do Homem, veremos dois exemplos de entendimento da neutralidade religiosa do Estado, com resultados completamente diferentes, devido à visão que cada um dos Estados envolvidos apresenta desse conceito.

Os acórdãos tratados no presente Capítulo foram escolhidos por serem os mais relevantes e recentes casos julgados por dois tribunais superiores com jurisdição no ordenamento jurídico português e com o objeto mais próximo ao do acórdão alemão em estudo, pretendendo, assim, ampliar a discussão sem, no entanto, fugir do cerne da dissertação.

Destacamos que, na falta de sentença cujo objeto fosse o hijab, escolhemos o acórdão 174/93, do Tribunal Constitucional português, por tratar-se do mais relevante Acórdão do TC que fala sobre a questão da neutralidade do Estado, abordada dentro do princípio de separação entre Igreja e Estado.

Já o acórdão Dahlab v. Suíça, de 15 de fevereiro de 2001, do TEDH, é o acórdão mais recente deste tribunal sobre o tema específico do hijab, e concretamente, da sua utilização por uma professora de escola pública, ou seja, exatamente o mesmo tema do acordão alemão objeto de estudo deste trabalho.

\section{a) Acórdão 174/93, do Tribunal Constitucional português ${ }^{29}$}

A questão tratada no acórdão 174/93, do Tribunal Constitucional português, concentrouse na possibilidade ou não dos professores do Estado assumirem a lecionação das aulas de Religião e Moral Católicas em escolas públicas, na qualidade de professores únicos.

$\mathrm{O}$ artigo $41^{\circ}$ da Constituição da República Portuguesa ${ }^{30}$ trata sobre a liberdade de consciência, de religião e de culto e traz, em si, a prescrição da separação entre o Estado e as igrejas/comunidades religiosas.

\footnotetext{
${ }^{29}$ Cfr. teor integral do acórdão 174/93, do Tribunal Constitucional português. [em linha]. [Consultado em 6 de abril de 2017]. Disponível em http://www.tribunalconstitucional.pt/tc/acordaos/19930174.html.

30 "Artigo $41^{\circ}$ [Liberdade de consciência, de religião e de culto]

1. A liberdade de consciência, de religião e de culto é inviolável.

2. Ninguém pode ser perseguido, privado de direitos ou isento de obrigações ou deveres cívicos por causa das suas convicções ou prática religiosa.
} 
Alegando o incumprimento do referido princípio da separação Igreja-Estado, previsto no citado art. $41^{\circ}$, um grupo de deputados intentou um pedido de inconstitucionalidade contra a Portaria 333/86 31 , que regulamenta a lecionação da disciplina de Religião e Moral Católicas no ensino primário, e contra a Portaria $831 / 87^{32}$, que estabelece as condições que permitem assegurar o ensino de Educação Moral e Religiosa Católica, na formação de educadores de infância e professores do $1^{\mathrm{o}}$ ciclo do ensino básico, pelas escolas superiores de educação e pelos centros integrados de formação de professores nas universidades.

O Tribunal Constitucional português entendeu não haver qualquer inconstitucionalidade nas portarias referidas, pois a separação entre a igreja e o Estado não proíbe o exercício da colaboração ${ }^{33}$. O Estado, na sua neutralidade, tem o dever de colaborar com a religião, permitindo o acesso da mesma a todos, e o facto dos professores do Estado, ainda que únicos, se qualificarem para lecionar a disciplina de Religião e Moral Católicas não se sobrepõe às prerrogativas da Igreja, mas, tão somente, colabora com essa instituição.

Como se pode assim ver na decisão em foco, a jurisprudência constitucional portuguesa entende que a neutralidade do Estado não significa eliminar a religião da vida educacional pública, restringindo-a ao âmbito interno de cada credo, mas sim, cooperar com as diferentes confissões para permitir o respetivo ensino religioso a quem possa interessar.

Esta visão sobre o conceito de neutralidade do Estado em relação à religião, ou seja, em relação à liberdade religiosa, adota contornos amplos, personificados na complementação das

\footnotetext{
3. Ninguém pode ser perguntado por qualquer autoridade acerca das suas convicções ou prática religiosa, salvo para recolha de dados estatísticos não individualmente identificáveis, nem ser prejudicado por se recusar a responder.

4. As igrejas e outras comunidades religiosas estão separadas do Estado e são livres na sua organização e no exercício das suas funções e do culto.

5. É garantida a liberdade de ensino de qualquer religião praticado no âmbito da respetiva confissão, bem como a utilização de meios de comunicação social próprios para o prosseguimento das suas atividades. 6. É garantido o direito à objeção de consciência, nos termos da lei”,

Cfr. Constituição da República Portuguesa de 1976. [em linha]. [Consultado em 28 de março de 2018]. Disponível em http://www.parlamento.pt/Legislacao/Paginas/ConstituicaoRepublicaPortuguesa.aspx.

${ }^{31}$ Texto integral da Portaria 333/86. Diário da República Eletrónico. [em linha]. [Consultado em 28 de março de 2018]. Disponível em https://dre.pt/pesquisa-avancada/-

/asearch/228620/details/maximized?serie=I\&search=Pesquisar\&ano=1986\&perPage=100\&types=DR\&dreId=90 $568 /$ en/en.

${ }^{32}$ Texto integral da Portaria 831/87. Diário da República Eletrónico. [em linha]. [Consultado em 28 de março de 2018]. Disponível em https://dre.pt/web/guest/pesquisa/-/search/496359/details/normal?q=portaria+831\%2F87.

${ }^{33}$ Cfr. acórdão 174/93, do Tribunal Constitucional português... cit., p. 47: "O princípio da separação não exclui, como se realçou anteriormente, toda e qualquer colaboração do Estado com a Igreja Católica. A colaboração com a finalidade de assegurar a liberdade religiosa, propiciando que nas escolas superiores de educação e nos centros integrados de formação de professores das universidades que formarem educadores de infância e professores do $1^{\circ}$ ciclo do ensino básico seja ensinada a disciplina de Educação Moral e Religiosa Católica e Sua Didáctica aos alunos que o quiserem, é constitucionalmente legítima, desde que, claro está, não seja o Estado a assumir, ele próprio, a tarefa e a responsabilidade do ensino".
} 
vertentes positiva e negativa do direito à liberdade religiosa das pessoas, sendo que à vertente positiva corresponde a função do Estado de cooperar com os pais na educação dos seus filhos, bem como o dever desse mesmo Estado de proporcionar o ensino religioso nas escolas públicas ${ }^{34}$.

O Tribunal Constitucional português utilizou adequadamente, aliás, dois princípios essenciais de um Estado democrático, quais sejam, o princípio do Estado social e o princípio da cooperação, corroborando que a liberdade dos cidadãos se realiza, quer através de prestações negativas (ou abstenções), quer através de prestações positivas por parte do Estado. Como salienta Jónatas Machado (1996, p. 339), a neutralidade não significa "indiferentismo ou passividade diante do fenômeno religioso" 35 .

Para além das razões jurídicas apresentadas, deve-se levar em conta, para concluir, as tradições, as raízes de cada País. Concretamente, Portugal, assim como o resto da Europa, tem uma rica história religiosa e, ao deixar de cooperar com as confissões, o Estado estaria, não apenas, a restringir o entendimento sobre a neutralidade, mas também, estaria a ferir as bases sobre as quais foi construída a nação ${ }^{36}$.

\footnotetext{
${ }^{34}$ Segundo Paulo Adragão, esta é, pois, uma visão "ampla da liberdade religiosa, liberdade negativa e positiva; liberdade individual, das famílias e das instituições religiosas; liberdade privada e pública. A vertente de direito positivo e a vertente de direito negativo representam aliás [...] perspectivas complementares. À vertente positiva da liberdade religiosa correspondem obrigações activas da parte do Estado, designadamente, o dever de cooperar com os pais na educação dos filhos e o dever de proporcionar às confissões religiosas o ensino nas escolas públicas". Cfr. ADRAGÃO, Paulo Pulido - A Liberdade Religiosa...cit., p. 19-20.

${ }^{35}$ Para aprofundamento sobre Estado social e sobre a cooperação, cfr. MACHADO, Jónatas Eduardo Mendes Liberdade Religiosa numa comunidade constitucional inclusiva - dos direitos da verdade aos direitos dos cidadãos. Studia Iuridica 18. Boletim da Faculdade de Direito da Universidade de Coimbra. Coimbra. Coimbra Editora, 1996. ISBN 972-32-0729-X. Acerca do princípio do Estado social, o autor refere: "No quadro do Estado social, a liberdade dos cidadãos depende não apenas de prestações negativas por parte do Estado, mas sim de prestações positivas” (p. 337). Sobre o princípio da cooperação, pode ler-se nas páginas 339-342.

${ }^{36}$ Elaboramos esta ideia a partir da seguinte passagem do texto de Andrea Bettetini: "Non si può negare che l'Europa affondi le proprie radici, oltre che nel patrimonio greco-romano, in quello religioso. Riconoscere tali radici non significa uno sterile sguardo al passato, al contrario, come bem evidenziava Simone Weil, la loro perdita è proprio il sintomo di decomposizione o di decadenza di uma civiltà". Tradução pessoal: "Não se pode negar que a Europa tem suas raízes, não apenas na herança greco-romana, mas também na religiosa. Reconhecer essas raízes não significa um olhar estéril para o passado, pelo contrário, como Simone Weil assinalou, sua perda é precisamente o sintoma da decomposição ou decadência de uma civilização". Cfr. BETTETINI, Andrea - Relazionalità della persona, rilevanza pubblica del fatto religioso e tolleranza, in ADRAGÃO, Paulo Pulido (coord.) - Atas do I Colóquio Luso-Italiano sobre Liberdade Religiosa. Coimbra. Almedina, 2014. ISBN 9789724054247. p. 31.
} 


\section{b) Acórdão Dahlab v. Suíça, de 15 de fevereiro de 2001, do Tribunal Europeu dos Direitos do Homem ${ }^{37}$}

No acórdão Dahlab v. Suíça, de 15 de fevereiro de 2001, o Tribunal Europeu dos Direitos do Homem julgou o caso de Lucia Dahlab, uma senhora de nacionalidade suíça, nomeada professora primária pelo Governo Cantonal de Genebra em 1 de setembro de 1990, e que, em março de 1991, abandonou o catolicismo e adotou a religião muçulmana, passando a usar o véu (hijab) no seu local de trabalho. Apesar de não ter havido qualquer reclamação por parte dos alunos ou dos pais, o Diretor Geral das Escolas Primárias do Cantão de Genebra solicitou, em 1996, que a professora deixasse de usar o véu, sob a alegação de que o uso do mesmo configuraria um risco à paz na escola e à neutralidade do Estado. Uma vez que a professora não atendeu à proibição imposta, veio a ser demitida no mesmo ano de 1996.

O Tribunal Europeu dos Direitos do Homem entendeu que a utilização do véu por uma professora poderia influenciar negativamente os alunos, impondo-lhes os preceitos de uma determinada religião, visto que os professores têm autoridade sobre os discentes.

Segundo a conclusão do Tribunal Federal da Suíça, entendida pelo TEDH como justificativa plausível para a proibição do uso do véu, a demandante ensinava numa escola primária, sendo os alunos crianças pequenas, facilmente impressionáveis. Por esse motivo, mesmo que a professora não fizesse proselitismo, ou não conversasse com os alunos sobre a sua religião, isso não evitaria que os mesmos fizessem perguntas a respeito do véu e, ainda que a professora mentisse sobre o seu real significado, justificando o uso do adereço por motivos de moda ou de frio, os alunos perceberiam algo diferente, subentendendo a existência de um problema que a professora estaria a tentar evitar. Por outras palavras, seria extremamente difícil para a professora responder às perguntas dos alunos sem mencionar a sua crença ${ }^{38}$.

Outro argumento apresentado pelo TEDH na sua decisão, foi o de que o uso do véu colocava a mulher em posição de inferioridade perante os homens e que tal atitude seria

\footnotetext{
${ }^{37}$ Cfr. teor integral do acórdão Dahlab v. Suíça, de 15 de fevereiro de 2001, do Tribunal Europeu dos Direitos do Homem. [em linha]. [Consultado em 10 de maio de 2017]. Disponível em http://hudoc.echr.coe.int/eng?i=00122643.

${ }^{38}$ Cfr., no original, acórdão Dahlab v. Suíça... cit., p. 6: "Furthermore, the appellant teaches in a primary school; her pupils are therefore young children who are particularly impressionable. Admittedly, she is not accused of proselytising or even of talking to her pupils about her beliefs. However, the appellant can scarcely avoid the questions which her pupils have not missed the opportunity to ask. It would seem somewhat awkward for her to reply by citing aesthetic considerations or sensitivity to the cold - the approach she claims to have adopted to date, according to the file - because the children will realise that she is evading the issue. It is therefore difficult for her to reply without stating her beliefs".
} 
inaceitável nos dias atuais ${ }^{39}$. Sobre este assunto, como já se referiu no Capítulo I desta dissertação, estudiosos islâmicos esclarecem que o véu nada tem a ver com a subjugação da mulher, mas, pelo contrário, visa protegê-la; sendo tal indumentária uma obrigação religiosa, um código de vestimenta feminino a ser cumprido, assim como também os homens possuem o seu código de vestimenta para cumprir.

Como se pode observar, o TEDH teve um entendimento extremamente restritivo do conceito de neutralidade do Estado. Ao acolher os argumentos do Estado suíço para proibir o uso do véu pela professora, o tribunal concordou com a visão de que a neutralidade do Estado consiste em eliminar o religioso do território público, confinando-o ao espaço privado, mesmo que isso signifique impedir que o fiel a uma confissão cumpra um dever religioso ${ }^{40}$.

Sem eximir o TEDH da responsabilidade pelo deficiente entendimento do conceito de neutralidade, devemos reconhecer que a fonte desse erro é de matriz suíça, tendo o Tribunal Europeu dos Direitos do Homem corroborado a visão do Tribunal suíço recorrido.

O ordenamento suíço, assim como o francês e o belga, adotam um modelo de neutralidade do Estado baseado na negação do religioso. A título de exemplo, citamos o caso da proibição da construção de minaretes nas mesquitas, fixada no art. $72^{\circ}, n^{\circ} 3$, da Constituição suíça, uma questão sobre a qual o TEDH se recusou a tomar qualquer decisão, alegando não terem os fiéis muçulmanos sofrido um dano concreto ${ }^{41}$. Com tal atitude, o TEDH ignorou por completo o dano identitário causado aos muçulmanos suíços, através da proibição constitucional supracitada ${ }^{42}$.

\footnotetext{
${ }^{39} \mathrm{Cfr}$., no original, acórdão Dahlab v. Suíça... cit., p. 14: "The Court also reiterates that the advancement of the equality of the sexes is today a major goal in the member States of the Council of Europe. This means that very weighty reasons would have to be advanced before a difference in treatment on the ground of sex could be regarded as compatible with the Convention".

${ }^{40}$ A este propósito, Cruz [et al] afirmam: "A violência de autorizar o emprego de símbolos religiosos não parece menor ou melhor que a violência de proibi-los. Nesse caso, a suposta neutralidade, que estaria embasada na preocupação de tratamento isonômico dos cidadãos, na realidade privilegiaria francamente ateístas e agnósticos, transformando os 'religiosos' em cidadãos de segunda classe. E, onde há preferência, não há neutralidade...”. Cfr. CRUZ, Álvaro Ricardo de Souza; DUARTE, Bernardo Augusto Ferreira; TEIXEIRA, Alessandra Sampaio - A Laicidade para além de Liberais e Comunitaristas. Vol. 08. Coleção Professor Álvaro Ricardo de Souza Cruz. Belo Horizonte. Arraes Editores, 2017. ISBN 978-85-8238-276-9. p. 26.

${ }^{41}$ Cfr. Decisão da Segunda Seção do TEDH sobre a receptividade do recurso Ouardiri v. Suíça, de 28 de junho de 2011, que o declarou inadmissível: "En l'espèce, la Cour relève que le requérant se plaint essentiellement que la disposition constitutionnelle litigieuse heurte ses convictions religieuses. Il ne met dès lors en avant aucun commencement d'application de celle-ci et n'allègue, par ailleurs, pas que celle-ci ait déployé un quelconque effet concret à son égard. De l'avis de la Cour, le requérant n'est donc pas directement victime de la violation alléguée de la Convention. En l'absence d'allégation quant aux effets de la modification constitutionnelle litigieuse sur ses proches, il ne saurait non plus être considéré comme une victime indirecte". [em linha]. [Consultado em 1 de junho de 2018]. Disponível em http://hudoc.echr.coe.int/eng?i=001-105619.

${ }^{42}$ Como salienta Patrícia Jerónimo: "Em toda esta análise, o TEDH parece pressupor que o único dano que pode resultar do artigo $72^{\circ}, \mathrm{n}^{\circ} 3$, da Constituição suíça, é a impossibilidade de construir um minarete. O TEDH não atende ao facto de a inscrição no texto constitucional de uma proibição absoluta de um símbolo identitário
} 
Como bem destaca Roberto Mazzola (2012, p. 143), no seu artigo Le contraddizioni dello Stato costituzionale di fronte ai fenomeni di intolleranza religiosa in Europa, a lamentável tendência do TEDH em corroborar entendimentos e decisões extremamente restritivas à liberdade religiosa, tomadas por alguns Países, leva-nos a questionar se esse tribunal tem, efetivamente, cumprido o seu papel de proteger o direito fundamental em foco ${ }^{43}$.

\section{c) Neutralidade-colaboração v. neutralidade-negação}

Conforme se observa nos casos relatados nas alíneas "a" e "b" deste Capítulo, enquanto a jurisprudência portuguesa entende que neutralidade significa "colaboração", a jurisprudência suíça entende o significado da mesma palavra como "negação".

Atualmente, é muito comum ouvirmos a expressão "laicidade" associada à "neutralidade" do Estado. Praticamente todos os Países democráticos se dizem Estados laicos, no sentido de prezarem a sua neutralidade. Mas, será que tal conceito está a ser devidamente empregado por todos?

Segundo Rafael Palomino (2011, p. 2), com o passar do tempo, os termos "laicidade", "neutralidade" e "secularismo" sofreram uma degradação de significado nos âmbitos político e legal, que acabou por causar a grande confusão terminológica vivida atualmente ${ }^{44}$.

Mais ainda, como conclui Paulo Adragão (2012, p. 512-517) $)^{45}$, os termos "neutralidade", "laicidade" e "separação absoluta" não passam de variações da mesma ideia, através das quais se mostra um fator limitador do Estado na tutela da liberdade do exercício da religião. O autor defende, ainda, que o Estado não deve adotar nenhuma destas vertentes

islâmico, sem paralelo para outras denominações religiosas, pode implicar uma humilhação - uma 'lesão estigmática' - para todos os muçulmanos residentes na Suíça, discriminando-os e marginalizando-os efetivamente". Cfr. JERÓNIMO, Patrícia - Intolerância religiosa e minorias islâmicas na Europa - A censura do "Islão visível" - os minaretes e o véu - e a jurisprudência conivente do Tribunal Europeu dos Direitos do Homem, in ADRAGÃO, Paulo Pulido (coord.) - Atas do I Colóquio Luso-Italiano sobre Liberdade Religiosa. Coimbra. Almedina, 2014. ISBN 9789724054247. p. 104.

${ }^{43}$ Como questiona Mazzola, no texto original: "La Corte di Strasburgo ha o non contribuito a rafforzare il grado di pluralismo religioso in Europa?”. Cfr. MAZZOLA, Roberto - Le contraddizioni dello Stato costituzionale di fronte ai fenomeni di intolleranza religiosa in Europa, in ADRAGÃO, Paulo Pulido (coord.) Atas do I Colóquio Luso-Italiano sobre Liberdade Religiosa. Coimbra. Almedina, 2014. ISBN 9789724054247. p. 143.

${ }^{44}$ Como refere o autor, no texto original: “All those terms ('laïcité', 'neutrality' and 'separation') have suffered a deflationary process in the political and legal sphere, as a result of which it is difficult to understand legally what kind of separation are we dealing with and to what measure religious freedom is protected satisfactorily". Cfr. PALOMINO, Rafael - Legal dimensions of secularism: challenges and problems, Madrid, Universidad Complutense. 2011. p. 2.

${ }^{45}$ Cfr. ADRAGÃO, Paulo Pulido - A Liberdade Religiosa...cit., p. 512-517. 
extremas, mas antes ser simpático à influência positiva da questão religiosa na vida política, adotando o modelo da não identificação com cooperação.

Voltando à autodenifição dos Estados como entidades firmadas na "laicidade", cumprenos verificar o real significado do termo, na sua relação com a "neutralidade".

De acordo com Jónatas Machado (1996, p. 306), “no contexto europeu, a doutrina costuma distinguir entre laicidade e laicismo. A primeira expressão pretende designar uma atitude de neutralidade benevolente por parte dos poderes públicos, respeitadora do religioso nas suas diversas manifestações, nos termos da qual estes se abstêm de tomar posição sobre o problema da verdade religiosa. A segunda, como resulta do texto, designa uma verdadeira filosofia ou ideologia, no sentido de conceção global do mundo, da existência e da conduta moral. Trata-se aqui de um 'dogma' antidogmático, de uma 'metafísica' antimetafísica, de um racionalismo antropológico que exclui qualquer referência teológica a uma verdade transcendente alicerçada na revelação" 46 .

Em consonância, Jorge Miranda (2013, p. 9) diz que "laicidade significa não assunção de tarefas religiosas pelo Estado e neutralidade, sem impedir o reconhecimento do papel da religião e dos diversos cultos. Laicismo significa desconfiança ou repúdio da religião como expressão comunitária e, porque imbuído de pressupostos filosóficos ou ideológicos (o positivismo, o cientismo, o livre pensamento ou outros), acaba por pôr em causa o próprio princípio da laicidade" $" 47$.

Javier Ortiz e Pedro-Juan Viladrich (2007, p. 94) fazem uma interessante divisão de conceitos e funções ao dizerem que uma coisa é o "direito" e outra é o "princípio da liberdade religiosa", sendo que ambos correspondem a dois passos sucessivos que o Estado democrático deve dar. O primeiro passo (direito de liberdade religiosa) exige que o Estado reconheça e garanta juridicamente uma plena imunidade de coação em matéria religiosa em favor dos cidadãos e das confissões, perante as demais e perante o próprio Estado. O segundo passo (princípio da liberdade religiosa) obriga o Estado a proibir-se de concorrer com os cidadãos na qualidade de sujeito de atos ou atitudes diante da fé e da religião, sejam de que sinal forem, positivo, negativo ou agnóstico ${ }^{48}$.

\footnotetext{
${ }^{46}$ Cfr. MACHADO, Jónatas Eduardo Mendes - Liberdade Religiosa numa comunidade ...cit., p. 306, nota de rodapé 1011.

${ }^{47}$ Cfr. MIRANDA, Jorge - Estado, Liberdade Religiosa e Laicidade. Gaudium Sciendi, №4 (Julho/2013), Universidade Católica - Sociedade Científica. p. 9.

${ }^{48}$ Cfr. ORTIZ, Javier Ferrer; VILADRICH, Pedro-Juan - Los principios informadores del derecho eclesiástico español, in ORTIZ, Javier Ferrer [et al] - Derecho Eclesiástico del ...cit., p. 94: “(...) una cosa es el derecho y otra el principio de liberdad religiosa, y que ambos corresponden a dos passos sucessivos que el Estado democrático debe dar para serlo. El primero le exige reconocer y garantizar juridicamente una plena
} 
Com base na divisão feita pelos autores citados no parágrafo anterior, podemos avançar que um Estado neutro, que entende "neutralidade" como "laicidade", segue os dois passos indicados, quais sejam, primeiro reconhece o direito de liberdade religiosa e, depois, aplica o princípio da liberdade religiosa.

Dada a análise até agora feita, julgamos compreender que o conceito de "neutralidadecolaboração" corresponde à "laicidade" verdadeira e própria, enquanto o conceito de "neutralidade-negação" corresponde ao "laicismo". O que parece ocorrer na Suíça e em vários outros Países europeus, é uma espécie de envenenamento da "laicidade" pelo "laicismo", uma vez que, apesar de a Constituição prever a neutralidade do Estado e a liberdade religiosa dos cidadãos, as atitudes tomadas pelo Governo e o entendimento distorcido das normas estabelecidas parecem levar a decisões e posicionamentos laicistas.

Tomando como referência a síntese de Álvaro Cruz [et al] (2017, p. 9), os posicionamentos extremos contaminam a laicidade e prejudicam a liberdade. Duas visões da sociedade se digladiam hoje: a visão liberal e a visão comunitarista. Quer numa, quer noutra, o extremismo é um mal a ser evitado ${ }^{49}$. Neste sentido, acreditamos que o caminho para a justa convivência num contexto pluralista está no equilíbrio entre o "eu" e a "comunidade".

Do ponto de vista liberal, afirma-se que o indivíduo tem absoluta autonomia, podendo exercer livremente e sem qualquer obstáculo a sua liberdade de ser crente, ateu ou agnóstico. Tal argumento acompanha uma interpretação literal da lei, seguindo uma decisão puramente procedimental, mas deixa de fora o eixo central desse direito, pois várias vezes já ficou evidenciado que ao dizer que se está a garantir a total liberdade de uns, na verdade, está-se, claramente, a retirar a liberdade de outros (como por exemplo, a proibição do uso do hijab, no caso Dahlab v. Suíça).

\footnotetext{
inmunidad de coacción en materia religiosa en favor de los ciudadanos y las confesiones frente a los demás y frente al proprio Estado. El segundo passo le obliga a prohibirse concurrir junto a los ciudadanos en calidad de sujeto de actos o actitudes ante la fe y la religión, sean del signo que fueren: positivo, negativo o agnóstico". ${ }^{49}$ Segundo Cruz [et al], a visão liberal baseia-se no "pressuposto cienticista de que é possível ao 'ser humano' ser neutro. O que essa pressuposição encobre, no entanto, é que também ela toma partido em favor de uma determinada concepção. Por outro lado, ela deixa transparecer a falta de hospitalidade da visão liberal, igualando laicidade a laicismo, sob o pretenso fundamento de, com isso, propiciar um tratamento isonômico (com o mesmo respeito e consideração) de todos. Ela falha de modo abissal justamente por materializar um tratamento privilegiado em relação a valores agnósticos e ateístas, reafirmando, nesse ponto, a postura cienticista. Além disso, ela supervaloriza uma dimensão atomizada do 'eu', esquecendo-se do fato de que o ser humano é também um 'nós' [...] De outro lado, a concepção comunitarista não é menos violenta. Ela abafa o 'eu' por um 'nós', como se houvesse mesmo uma impossibilidade de ser diferente, enfim, existir diferentemente daquilo que propugnam os valores da comunidade política. Há um superdimensionamento do 'nós' que caminha na direção do aniquilamento do 'indivíduo'. Assim, a cultura e a tradição se tornam bens intransponíveis à autonomia do sujeito". Cfr. CRUZ, Álvaro Ricardo de Souza [et al] - A Laicidade para além...cit., p. 9.
} 
Do ponto de vista dos argumentos comunitaristas, a opção de excluir o cunho religioso de certos objetos, ou de simplesmente dizer que os mesmos fazem parte da cultura local secularizada, nada mais é do que, por um lado, passar por cima da sacralidade desses objetos, desvalorizando a confissão a que pertencem (como é notório no caso Lautsi v. Itália ${ }^{50}$ ), e por outro lado, excluir o indivíduo, fazendo com que o coletivo se sobreponha ao individual e o "bem" anteceda o "justo" 51 .

Como bem lembra Patrícia Jerónimo (2010, p. 501) ${ }^{52}$, ao tecer um comentário sobre os casos Sahin v. Turquia ${ }^{53}$ e Dogru v. França ${ }^{54}$, ambos envolvendo alunas muçulmanas, julgados pelo TEDH, respetivamente, em 2005 e 2008, “num espaço público neutro, todos os indivíduos devem ser livres para expressar as suas convicções religiosas ou filosóficas, a menos que usem de violência ou exerçam pressão sobre outras pessoas para que adiram àquelas convicções. Em Sahin e Dogru, lamentavelmente, o Tribunal Europeu dos Direitos do Homem, considerou que o uso do véu islâmico constitui, de per se, uma forma de proselitismo e de violência, pelo que aceitou como necessária a proibição do uso do véu nas universidades turcas e nas escolas secundárias francesas para proteger os direitos e as liberdades dos outros e garantir a ordem e a segurança pública" ${ }^{" 55}$. O TEDH estendeu às alunas a mesma restrição, em nosso entender, discutível, já imposta a uma professora em 2001, no caso Dahlab.

\footnotetext{
${ }^{50}$ Tomemos como exemplo o caso Lautsi v. Itália, onde uma mãe contestou a presença de crucifixos nas salas de aula de escolas públicas. Em reposta, o Estado italiano utilizou o argumento de que o crucifixo seria um objeto secularizado e neutro, que tão-somente, expressava valores já inseridos na cultura da sociedade. Cfr. CAMPOS, Manuel Fontaine - Da intolerância com as crenças minoritárias à intolerância com as crenças maioritárias - a propósito dos acórdãos do TEDH no caso Lautsi, in ADRAGÃO, Paulo Pulido (coord.) - Atas do I Colóquio Luso-Italiano sobre Liberdade Religiosa. Coimbra. Almedina, 2014. ISBN 9789724054247. p. 223-

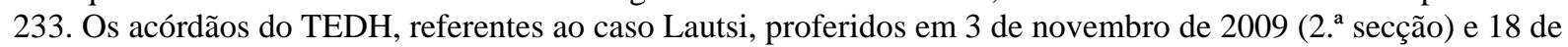
março de 2011 (tribunal pleno), estão disponíveis em

https://hudoc.echr.coe.int/eng\#\{\%22languageisocode\%22:[\%22ITA\%22],\%22docname\%22:[\%22CASE\%20OF \%20LAUTSI\%20v.\%20ITALY\%22]\}.

${ }^{51}$ Cfr. CRUZ, Álvaro Ricardo de Souza [et al] - A Laicidade para além...cit., p. 31.

52 JERÓNIMO, Patrícia - Símbolos e símbolos - o véu islâmico na jurisprudência...cit., p. 501.

${ }^{53}$ Teor integral do acórdão Sahin v. Turquia, de 10 de novembro de 2005, do TEDH. [em linha]. [Consultado em 4 de junho de 2018]. Disponível em https://hudoc.echr.coe.int/eng\#\{\%22itemid\%22:[\%22001-70956\%22]\}.

${ }^{54}$ Teor integral do acórdão Dogru v. França, de 04 de dezembro de 2008, do TEDH. [em linha]. [Consultado em 4 de junho de 2018]. Disponível em https://hudoc.echr.coe.int/eng\#\{\%22itemid\%22:[\%22001-90039\%22]\}.

${ }^{55}$ Convém distinguir os conceitos de proselitismo legítimo e proselitismo ilegítimo. Esclarecedor dos dois conceitos é o caso Kokkinakis v. Grécia, julgado pelo TEDH, em 1993, onde o tribunal deu ganho de causa ao Sr. Kokkinakis, após este ter sido condenado pelo Estado por proselitismo (previsto como crime no ordenamento jurídico grego). Seguindo os preceitos da sua religião, o Sr. Kokkinakis e a sua esposa, ambos testemunhas de Jeová, entraram em contato com a Sra. Kyriakaki e mantiveram com ela uma discussão sobre religião. Ao saber do ocorrido, o Sr. Kyriakaki, cantor da Igreja Ortodoxa Grega, contactou a polícia e denunciou o Sr. e a Sra. Kokkinakis pela prática de proselitismo, ao que os mesmos foram detidos e condenados. Em sede do TEDH, este tribunal entendeu que o proselitismo exercido pelos Kokkinakis não feria o direito de liberdade religiosa da Sra. Kyriakaki, uma vez que a discussão foi mantida a um nível razoável e sem uso de violência. Vemos aqui, uma diferenciação entre proselitismo legítimo e proselitismo ilegítimo (ou violento), sendo que o simples fato de manifestar, discutir, dar a conhecer uma determinada religião constitui um ato legítimo e não fere o art. $9^{\circ} \mathrm{da}$
} 
Neste sentido, conclui a mesma autora, num texto posterior $(2014$, p. 87): “[...] poderse-á dizer que o problema não reside propriamente no Islão enquanto fé e que as manifestações de intolerância e de discriminação dirigidas contra os muçulmanos se devem, em boa medida, ao generalizado clima de hostilidade que existe na Europa contra os imigrantes e as minorias étnicas $[\ldots]^{\prime 56}$.

Tratando esta dissertação de um julgado que envolveu o véu islâmico e observando a tendência do TEDH para acolher os posicionamentos laicistas dos Estados, quando o cerne da questão é a confissão muçulmana, não poderíamos deixar de questionar se a restrição à liberdade religiosa em análise é mesmo uma questão "religiosa" ou não será, também (para não dizer, apenas), um conflito de cunho social, migratório, que se concretiza na aversão à religião dos imigrantes.

No caso Lautsi, já citado, o TEDH, no Acordão do Pleno (2011), entendeu que não seria proselitismo nem desrespeito à neutralidade do Estado a manutenção dos crucifixos nas salas de aula das escolas públicas italianas ${ }^{57}$, mas em 2001, 2005 e 2008, respetivamente, nos casos Dahlab, Sahin e Dogru, o mesmo TEDH já havia considerado que o uso do véu islâmico, por uma professora e por duas alunas, era um grave desrespeito à neutralidade do Estado e feria a liberdade religiosa de terceiros.

Os atrozes atentados ocorridos nos Estados Unidos, em 11 de setembro de 2001, reforçaram, entretanto, o já existente estereótipo contra o Islão e generalizaram o medo, acirrando a intolerância religiosa contra o mesmo, no Ocidente. Posteriormente, os sucessivos ataques terroristas ocorridos na Europa, só pioraram um já tenso clima entre os muçulmanos e a restante sociedade.

Nesse contexto de tensão social, a responsabilidade dos Estados de exercerem devidamente o seu papel de protetores dos direitos fundamentais, em especial, do direito à liberdade religiosa, torna-se ainda mais notória. Aos Estados compete praticar uma neutralidade

CEDH. Pelo contrário, o proselitismo ilegítimo baseia-se na violência e na subjugação do outro a uma determinada crença. Cfr. teor integral do acórdão Kokkinakis v. Grécia, de 25 de maio de 1993, do TEDH. [em linha]. [Consultado em 4 de junho de 2018]. Disponível em http://hudoc.echr.coe.int/eng?i=001-57827.

${ }^{56}$ JERÓNIMO, Patrícia - Intolerância religiosa e minorias islâmicas na Europa - A censura do "Islão visível" - os minaretes e o véu - e a jurisprudência conivente do Tribunal Europeu dos Direitos do Homem, in ADRAGÃO, Paulo Pulido (coord.) - Atas do I Colóquio...cit., p. 87.

${ }^{57}$ Apesar de não ter acolhido o argumento do Governo italiano de que o crucifixo seria um objeto já com valores secularizados e inseridos na sociedade, o TEDH entendeu que, mesmo sendo um objeto eminentemente religioso, a visão do crucifixo não apresenta risco à laicidade do Estado (para nós, neutralidade-colaboração), nem fere a liberdade religiosa de não cristãos. (Cfr. nota (49)). 
colaborante, livre de vícios que a maculem e a tornem laicismo, sabendo separar o bem e o mal, o trigo do joio.

Numa sociedade composta por milhões de pessoas, naturalmente, haverá sempre alguns indivíduos com preconceitos, dispostos a ofender e agredir quem lhes parecer diferente e for estranho ao seu universo familiar. Mas, para esse mal, a prevenção deverá ser o Estado garante de direitos, atuando de forma neutra e colaborativa, proporcionando a integração e o esclarecimento.

Voltemos a falar da senhora muçulmana Nadia Ettaouass ${ }^{58}$, residente na cidade do Porto, que declarou haver deixado de usar o hijab após ter sofrido episódios de intolerância, para estabelecer uma comparação entre os Estados no cumprimento das suas funções, enquanto garante de direitos.

A Sra. Nadia, como residente em Portugal, um País que pratica a neutralidadecolaboração (laicidade), recebe do Estado o devido apoio para exercer o seu direito fundamental à liberdade religiosa e, se quiser, poderá recorrer à justiça contra quem quer que a impeça de professar a sua fé na integralidade e como lhe aprouver. Uma situação semelhante ocorreria se a Sra. Nadia residisse na Alemanha, uma vez que na decisão proferida pelo TC alemão em 2015, o tribunal aplicou corretamente o conceito neutralidade-colaboração.

Diferentemente seria, caso a mesma senhora muçulmana fosse residente na Suíça, País onde parece prevalecer uma tendência laicista na jusrisprudência, que se rege pela neutralidadenegação, na qual a religião é relegada para o esconderijo do espaço privado e onde não convém que a pluralidade seja "visível".

Não obstante a distinção que fazemos entre os conceitos de "neutralidade-colaboração" e "neutralidade-negação", cumpre-nos ressaltar a divergência de entendimentos quanto à aplicação do vocábulo "neutralidade", da parte dos Estados.

Como chama a atenção Paulo Adragão (2002, p. 264-265) ${ }^{59}$, a expressão "neutralidade religiosa" originou-se nas teses francesa (laicista) e rawlsiana (contratualista e formalista), que têm em comum o desconhecimento da dimensão social do fenómeno religioso, da parte do poder político.

Assim, apesar do uso da palavra "neutralidade", indistintamente, pelos diferentes Estados e tribunais (inclusive o TC alemão), o termo não caracterizaria corretamente o sistema de não-identificação, não-indiferença e não-intervenção adotado pela Alemanha, no que diz

\footnotetext{
${ }^{58}$ Ver capítulo I, páginas 19-20.

${ }^{59}$ Cfr. ADRAG ÃO, Paulo Pulido - A Liberdade Religiosa... cit., p. 264-265.
} 
respeito à relação entre o Estado e a religião. Em alternativa, propomos a expressão, mais completa, de "neutralidade-colaboração" como sendo a mais adequada à situação concreta do ordenamento alemão.

Conclui-se que o princípio da separação das confissões religiosas do Estado, entendida como neutralidade-colaboração, para além da efetiva proteção do exercício da liberdade religiosa, tanto positiva como negativa, visa, ainda, a preservação e o fomento do diálogo entre as diversas ideias e conceções de vida abarcadas no seio de uma sociedade democrática e plural. 


\section{Capítulo IV - A Alemanha e o tratamento da liberdade religiosa}

\section{a) Panorama da Alemanha atual: imigrantes e população - o islamismo na Alemanha}

Com a maior economia da União Europeia, a Alemanha, que também é o mais populoso País da UE, tornou-se o destino de muitos imigrantes em busca de melhores condições de vida. Essa procura pela Alemanha ganhou ainda mais força com a política de portas abertas adotada pela Chanceler alemã, Angela Merkel, em 2015, que abriu as fronteiras do País a milhares de refugiados.

Conforme dados oficiais do Gabinete Estatístico Federal (Destatis - Statistisches Bundesamt $)^{60}$, no final de 2016, a população total da Alemanha era de 82,5 milhões de pessoas, com previsão de aumento para 82,8 milhões em 2017, devendo-se esse aumento, principalmente, à imigração.

Ainda conforme o Destatis, o número de imigrantes registados, em 2017, teve um crescimento de 5,8\% em relação a 2016, totalizando um contingente de cerca de 10,6 milhões de pessoas apenas com cidadania estrangeira ${ }^{61}$.

Assim, concluiu-se que $11,2 \%$ da população residente na Alemanha é de estrangeiros, como informa a Pordata - Base de Dados Portugal Contemporâneo, num quadro sobre a Europa $^{62}$.

Grande parte das pessoas que imigram para a Alemanha pertencem à confissão muçulmana. Muitas delas são refugiadas, causando, assim, um considerável aumento do número de praticantes do islamismo no País.

Conforme dados do instituto de pesquisa Pew Research Center ${ }^{63}$, entre os anos de 2010 e 2016, a Alemanha recebeu cerca de 670 mil refugiados, sendo $86 \%$ deste montante, muçulmanos. Fora os refugiados asilados no País, foram recebidos, também, 680 mil imigrantes regulares, vindos de fora da União Europeia, dos quais $40 \%$ muçulmanos.

\footnotetext{
${ }^{60}$ Cfr. Destatis - Statistisches Bundesamt. [em linha]. [Consultado em 23 de abril de 2018]. Disponível em https://www.destatis.de/DE/Startseite.html.

${ }^{61} \mathrm{O}$ Destatis ressalta, em nota, que esse número de registos conta também com casos de pessoas que imigraram antes de 2017, mas foram registadas com atraso.

${ }^{62}$ Cfr. Pordata - Base de Dados Portugal Contemporâneo. [em linha]. [Consultado em 23 de abril de 2018]. Disponível em https://www.pordata.pt/MicroPage.aspx?DatabaseName=Europa\&MicroName=Popula\%C3\%A7\%C3\%A3o+est rangeira+em+percentagem+da+popula\%C3\% A7\%C3\%A3o+residente\&MicroURL=1624\&.

${ }^{63}$ Cfr. Pew Research Center. [em linha]. [Consultado em 23 de abril de 2018].Disponível em http://www.pewresearch.org/.
} 
Dessa forma, entre os anos de 2010 e 2016, o número de muçulmanos residentes na Alemanha aumentou de 3,3 milhões para 5 milhões, perfazendo um total de $6 \%$ da população do País.

Em relação aos refugiados, cumpre-nos ressaltar que, até agora, temos contado apenas aqueles que tiveram o seu pedido de asilo acolhido. Na realidade, a Alemanha recebeu, ainda, outros 540 mil requerentes de asilo, cujos pedidos foram rejeitados ou espera-se que o sejam.

As pesquisas mais recentes mostram que a tendência é um crescimento contínuo do número de muçulmanos na Alemanha. Tal aumento deve-se, além da imigração, também a outros fatores, como a taxa de natalidade e a idade média da população.

Para a população muçulmana, cuja idade média é de 31 anos, a previsão é de que cada indivíduo tenha, em média, 1,9 filhos até o ano de 2020. Estes números são bem vantajosos quando comparados aos 47 anos de idade média e expectativa média de 1,4 filhos até 2020, para cada indivíduo da população não muçulmana.

Como se pode verificar na Figura 2, fazendo uma projeção até o ano de 2050, o Instituto Pew Research, com base em três cenários diferentes, quais sejam, a interrupção total da imigração (zero imigração), a receção apenas de imigrantes regulares/não refugiados (imigração média) e a receção de imigrantes regulares e de refugiados (alta imigração), verificou que, em qualquer dos casos, o número de muçulmanos na Alemanha irá aumentar graças aos fatores relativos à idade média da população e à taxa de natalidade.

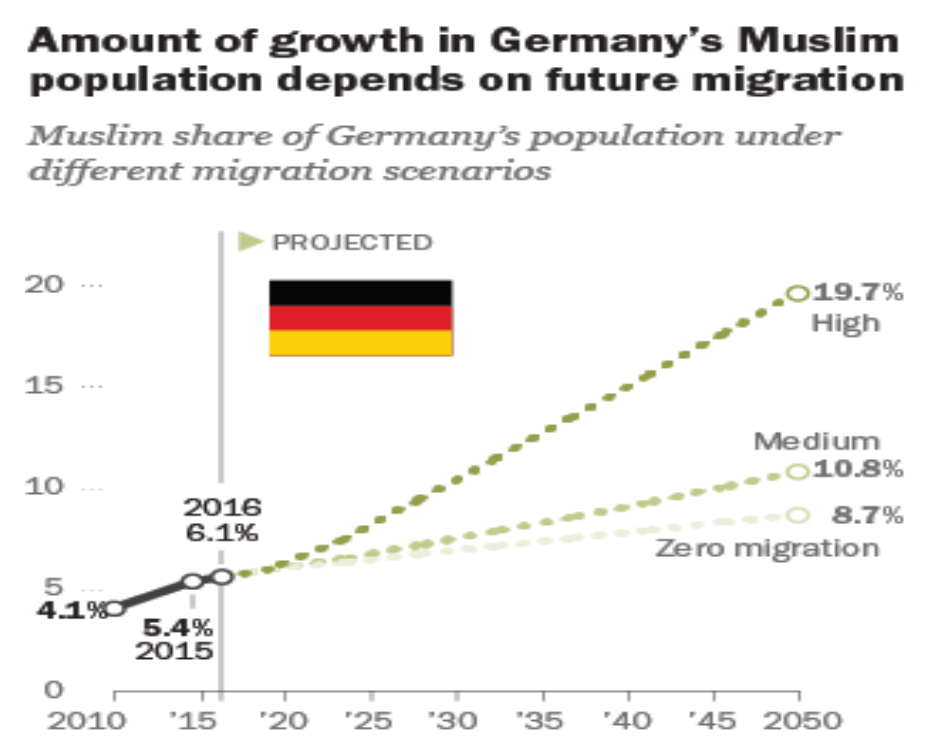

Figura 2.

Fonte: Pew Research Center ${ }^{64}$

\footnotetext{
${ }^{64}$ Disponível em http://www.pewforum.org/graphicsessay_pngoutput_germany_projection310px/. [Consultado em 23 de abril de 2018].
} 
Apesar do crescimento exponencial da população muçulmana na Alemanha, os cristãos ainda são a grande maioria, seguidos pelos não religiosos e, em terceiro lugar, os adeptos do Islão. As outras religiões dividem entre si uma percentagem bastante pequena da população.

Mesmo com o crescimento previsto para o islamismo na Alemanha, o número de cristãos, apesar de diminuir, ainda assim continuará superior ao número de fiéis das restantes confissões religiosas e ao número de não religiosos, como se pode ver na projeção estimada pelo Pew Research Center, que tem como base de comparação os anos 2010 e 2050 (Figuras 3 e 4$)^{65}$.

Germany All Population, 2010

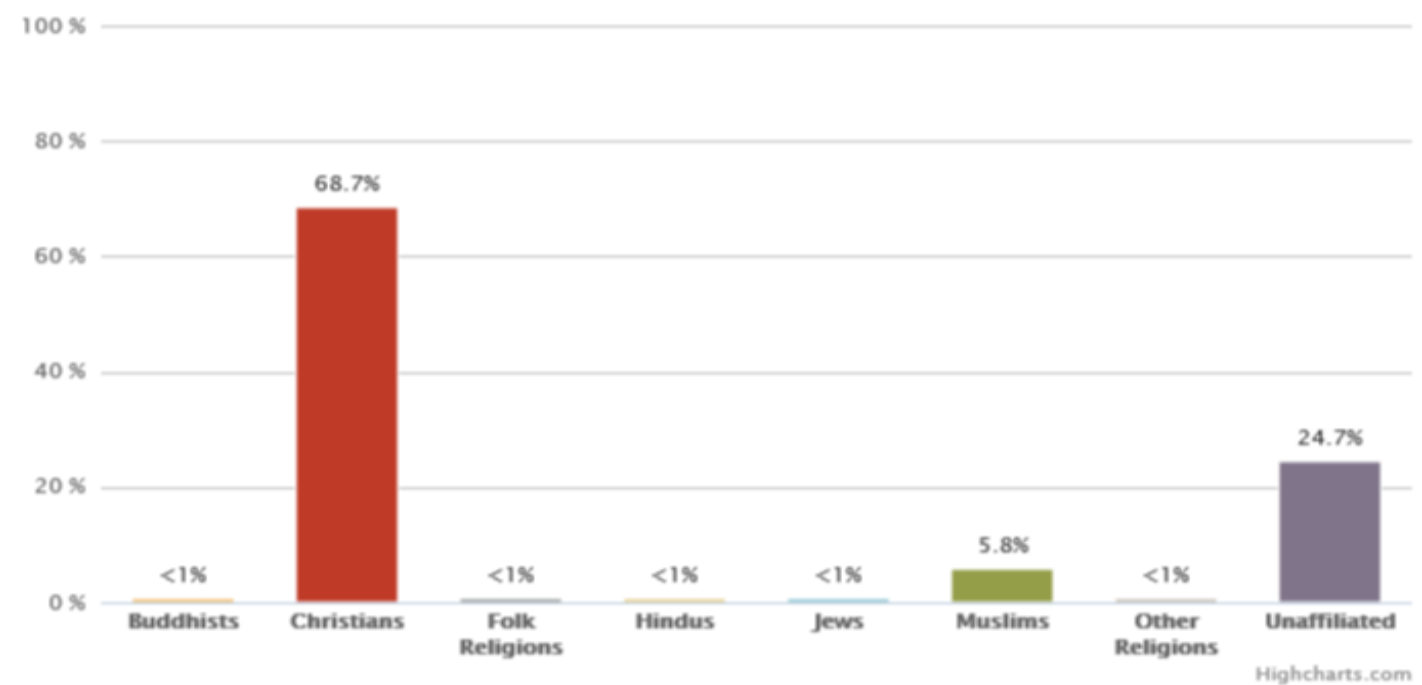

Figura 3.

Fonte: Pew Research Center

\footnotetext{
${ }^{65}$ Disponível em

http://globalreligiousfutures.org/explorer/custom\#/?subtopic=15\&countries=Germany\&chartType=bar\&data_typ e=percentage \&year=2050\&religious_affiliation=all\&age_group=all\&pdfMode=false\&gender=all. [Consultado em 23 de abril de 2018].
} 


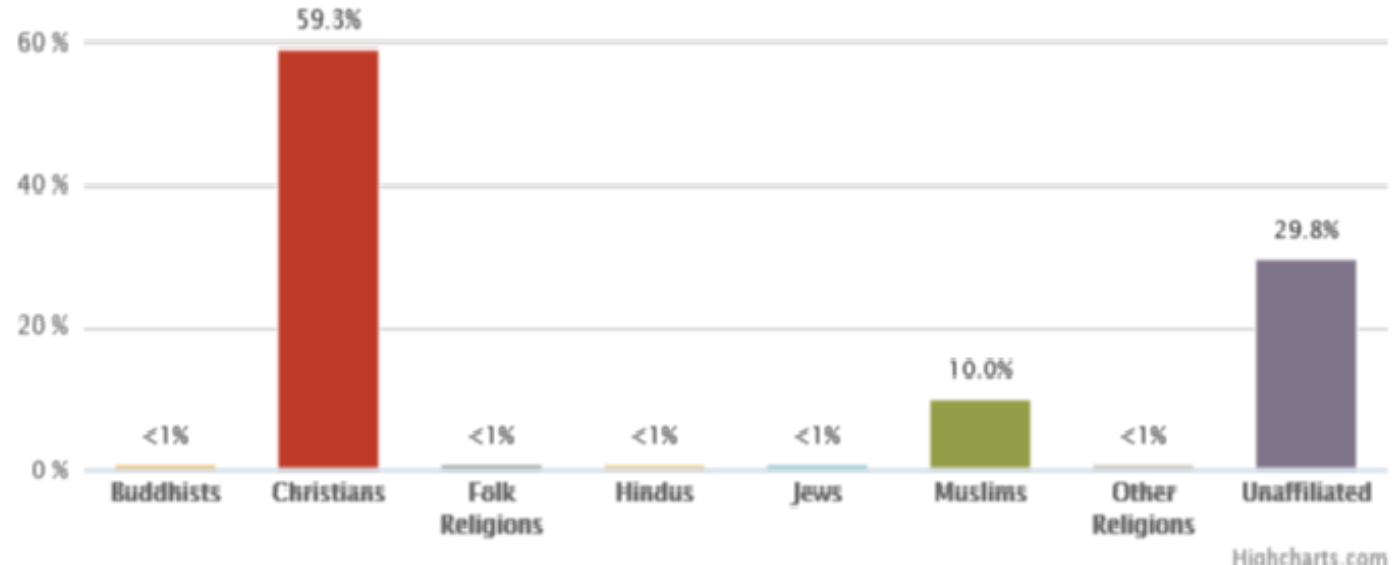

Figura 4.

Fonte: Pew Research Center

Geralmente, quando ocorre um processo de imigração massiva, setores como a educação e o mercado de trabalho são os primeiros a serem afetados pelo novo contingente, seja pelo excesso de procura, seja pela diferença de tratamento entre imigrantes e autóctones.

De acordo com informações do Destatis ${ }^{66}$, os imigrantes e os seus descendentes ainda se encontram significativamente em desvantagem, tanto na educação como no mercado de trabalho. Desde 2005, tais diferenças têm-se mantido inalteradas, o que mostra a existência de falhas na adequada integração dos imigrantes na sociedade local.

Utilizando um indicador central de educação, para calcular a proporção de jovens entre os 18 e os 24 anos que não possuíam um certificado de conclusão escolar, verificou-se que, em 2016, apenas 4\% dos autóctones se integravam nessa situação, contra uma percentagem de $12,1 \%$ de imigrantes sem certificado de conclusão escolar. Entretanto, ressalta-se que, entre os anos de 2011 e 2016, houve um aumento na proporção de imigrantes com baixa escolaridade, passando de $8,9 \%$ para $16,1 \%$.

${ }^{66}$ Cfr. Destatis - Statistisches Bundesamt - Integrationsindikatoren 2005-2016: Menschen mit

Migrationshintergrund haben weiterhin Nachteile (Integração 2005-2016: pessoas com antecedentes migrantes continuam a ter desvantagens). [em linha]. [Consultado em 23 de abril de 2018]. Disponível em https://www.destatis.de/DE/PresseService/Presse/Pressemitteilungen/2017/11/PD17_413_12521.html;jsessionid =71B37464FD271EAE0FAE18C14A5C8388.InternetLive1. 
No campo do trabalho, entre os anos de 2005 e 2016, graças ao bom momento da economia alemã, observou-se uma melhoria feliz, tanto para imigrantes como para nacionais, apesar da diferença entre uns e outros ainda ser bastante expressiva. Utilizando um indicador de participação no mercado de trabalho, calculou-se a percentagem de pessoas desempregadas na faixa etária entre os 15 e os 64 anos. No grupo dos autóctones, a percentagem de desempregados caiu de 9,8\% para 3,4\%, e no grupo dos imigrantes desceu de $17,9 \%$ para $7,1 \%$.

Também o rendimento dos imigrantes continua bem inferior ao rendimento dos nacionais. Com base no indicador que classifica o trabalhador como "pobre", verificou-se que a percentagem de imigrantes nessa condição é mais do dobro da percentagem de autóctones, sendo $13,6 \%$ de imigrantes trabalhadores "pobres" em face dos $6,2 \%$ de trabalhadores nacionais igualmente "pobres".

As diferenças numéricas supra referidas, levam-nos, novamente, a questionar a origem da discriminação derivada da restrição excessiva da liberdade religiosa. Estará em causa uma diferença religiosa ou uma diferença social? Nesse sentido, a religião não seria o ponto central do problema, mas sim, um fator identificador e justificador para a rejeição do diferente.

Nas últimas décadas, foi possível observar, na Europa, o fortalecimento dos partidos nacionalistas e de extrema direita, que têm como principal bandeira a rejeição dos imigrantes, notadamente, dos imigrantes muçulmanos.

Xenofobia e islamofobia tornaram-se plataformas comuns dos partidos populistas, que, apesar de (ainda) não terem alcançado a direção de governos, exercem uma forte influência sobre a opinião pública e, consequentemente, nas políticas adotadas pelos respectivos Países.

Considerado como um País recetivo e imune a exacerbações xenófobas (muito em função do triste histórico do período nazi, que estigmatizou os alemães e fez com que este povo se sentisse na obrigação moral de se redimir perante a humanidade), nos últimos anos, a Alemanha, assim como o resto da Europa, conheceu um fortalecimento dos partidos e discursos nacionalistas.

Desde 2005, a Alemanha vem sendo governada pela Chanceler Angela Merkel, líder do partido de centro-direita União Democrata Cristã (CDU). Intérprete de uma postura moderada, Angela Merkel que, até então, espelhava a imagem complacente da Alemanha declarou, em outubro de 2010: "Dizer que um belo dia, pronto, chegamos ao multiculticulturalismo, uns 
vivem ao lado dos outros e todo mundo está contente - pois bem, isso fracassou, fracassou totalmente [...] o que se aplica aqui é a Lei Fundamental, e não a Sharia" ${ }^{\prime 67}$.

A polémica declaração da Chanceler alemã foi dada um mês após a publicação do livro de Thilo Sarrazin, A Alemanha se extingue a si mesma, onde o autor faz uma apologia da xenofobia e da islamofobia. O sucesso do livro e o estrondoso apoio da população às ideias de Sarrazin fizeram a líder alemã, que inicialmente criticou e recriminou a obra, adotar um discurso mais duro sobre o multiculturalismo e, particularmente, sobre os muçulmanos.

Curiosamente, em 2015, como já foi mencionado no início deste título, Merkel adotou uma política de portas abertas para a receção de refugiados, acolhendo milhares de pessoas na Alemanha, a maioria, muçulmanos.

Talvez em razão dos infelizes ataques terroristas, inadequadamente justificados com fins religiosos pelos seus autores, aliada à sua inconfundível expressão estética, nomeadamente visível nas vestimentas, o Islão tornou-se o principal alvo da guerra político-social, na qual a restrição à liberdade religiosa dos seus fiéis tem sido a arma preferida dos Estados.

Como bem menciona Roberto Mazzola (2014, p. 142-143), “o mais perturbador é o facto de que a intolerância religiosa parece não ser mais direito exclusivo da extrema direita, nem esses fenômenos parecem estar limitados às franjas mais ideológicas da sociedade. Pelo contrário, as camadas moderadas da sociedade civil estão cada vez mais envolvidas: homens e mulheres plenamente integrados que apoiam e acreditam defender, ao fazê-lo, as suas liberdades e os seus direitos. O que estamos testemunhando, por outras palavras, é a crescente 'banalização' da intolerância em relação à diversidade"68.

Historicamente rechaçados para guetos e para a periferia de muitas cidades europeias, os imigrantes muçulmanos, apesar de viverem, trabalharem e constituírem família nos Países para onde se deslocaram, dificilmente são tratados como iguais pelos nacionais. A este propósito, salientamos as entrevistas realizadas com o Sheikh Davi Munir ${ }^{69}$ e com o Professor

\footnotetext{
${ }^{67}$ Cfr. Apud TODOROV, Tzvetan - Os inimigos íntimos ...cit., p. 165-167.

${ }^{68}$ Cfr. MAZZOLA, Roberto - Le contraddizioni dello Stato costituzionale di fronte ai fenomeni di intolleranza religiosa in Europa, in ADRAGÃO, Paulo Pulido (coord.) - Atas do I Colóquio...cit., p. 142-143: "Ma ciò che più inquieta è il fato che l'intolleranza religiosa appia non essere più appannaggio exclusivo dela estrema destra, né tali fenomeni risultano essere circoscritti alle sole frange più ideologizzate dela società. Al contrario, ad essere coinvolti sono sempre più gli strati moderati dela società civile: uomini e donne pienamente integrati che sostengono e credono, così facendo, di difendere le loro libertà e i loro diritti. Ciò a cui si assiste, in altri terminni, è la crescente 'banalizzazione' dela insofferenza verso la diversità'.

${ }^{69} \mathrm{Cfr}$. Anexo B - Entrevista com o Sheikh Davi Munir.
} 
Mahmoud $^{70}$, nas quais, ambos reforçam a necessidade de integração dos cidadãos muçulmanos na sociedade ocidental, sejam eles imigrantes ou não.

A diferença de tratamento dada aos imigrantes muçulmanos gera consequências de identidade. Como referiu o Sheikh Munir, na entrevista concedida, a tradição e a identidade islâmicas são muito fortes, muitas vezes mais fortes do que a própria identidade nacional, ressaltando que muitos jovens muçulmanos, nascidos no Ocidente, não se consideram ocidentais, devido à ascendência que possuem. $\mathrm{O}$ facto de os seus pais, avós, bisavós, etc., não terem sido devidamente acolhidos pelos ocidentais, faz com que esses jovens, que seguem a fé e a tradição islâmicas não se sintam parte integrante de uma sociedade que não acolhe bem a sua cultura.

Para completar as considerações feitas, finalizamos este título com a análise dos resultados obtidos num inquérito feito a professores de escolas públicas da cidade de Munique, onde os mesmos foram questionados sobre a questão religiosa e muçulmana ${ }^{71}$.

Responderam ao inquérito sete professores, com idades entre 30 e 57 anos, que preferiram manter o anonimato. A idade ou o tempo de serviço não foram determinantes para o resultado das respostas.

Quando questionados, os professores alemães foram levados a pronunciar-se sobre se a visão de símbolos religiosos lhes gerava incómodo. As opiniões ficaram divididas, porém, ficou clara uma maior resistência a símbolos não cristãos, ou seja, fora da tradição alemã.

Apesar de praticamente todos terem algum contato com muçulmanos, observou-se um total desconhecimento do real significado do hijab, que ainda foi muito relacionado pelos inqueridos com a submissão feminina.

\section{b) O sistema alemão de relações Igreja-Estado}

O atual Estado alemão, que assume uma postura de não identificação, de não indiferença e de não intervenção do poder político face às confissões religiosas, é, no nosso entender, um exemplo a ser seguido.

Historicamente, com o advento da Paz de Augsburgo, em 1555, e da Paz de Westfália, em 1648, passou a vigorar, na Alemanha, o chamado princípio cuius regio, eius religio. Este

\footnotetext{
${ }^{70}$ Cfr. Anexo A - Entrevista com o Professor Mahmoud.

${ }^{71}$ Cfr. Anexo D - Inquérito a professores de escolas públicas de Munique (Alemanha).
} 
princípio significava que, apesar da Reforma do século XVI ter rompido com a hegemonia católica romana no Sacro Império Romano-Germânico, não havia uma verdadeira liberdade religiosa. Os indivíduos não eram livres para escolher a sua confissão; tal opção era uma prerrogativa do soberano, havendo apenas duas possibilidades, aderir à confissão católica ou à confissão luterana. Mais tarde, também a confissão calvinista passou a ser permitida, mas as restantes denominações continuaram excluídas, cabendo aos indivíduos que discordassem a possibilidade de emigração para onde a sua preferência religiosa vigorasse ${ }^{72}$.

Foi na breve Constituição do Reich de 1849, caracterizada pela desconfessionalização do Estado, que a Alemanha incluiu preceitos pro libertate, como enumera Paulo Adragão (2002, p. 186): "reconheceu o direito de exercício coletivo, público e privado, a todas as confissões, o direito de associação em sociedades religiosas e o gozo de direitos civis (ou cívicos) e políticos, independentemente da convicção religiosa" ${ }^{\text {73 }}$. Ressalta-se que, em 1850, o então rei da Prússia, Frederico Guilherme IV, editou a primeira Constituição da Prússia, na qual a desconfessionalização foi a única disposição excluída do texto legal.

Ainda conforme a pesquisa de Paulo Adragão (2002), em $1871^{74}$, passou a vigorar, em todo o Estado alemão, uma lei, que havia sido originariamente estabelecida no norte do País, em 1869, que visava determinar a igualdade legal para todas as religiões, relativamente a matérias civis e políticas.

Após a exclusão da desconfessionalidade, pela Prússia, na sua Constituição de 1850, tal condição voltaria a figurar expressamente no texto legal da Constituição de Weimar, em 1919, garantindo a liberdade religiosa e ressaltando três liberdades individuais, quais sejam, a liberdade de profissão de fé, a liberdade de exercício da religião e a liberdade de associação religiosa.

No sombrio período entre 1933 e 1945, o regime totalitário vivido pela Alemanha exerceu uma oposição absoluta do Estado contra a religião. Entretanto, visando assegurar garantias mínimas formais para a atividade da Igreja Católica, a Santa Sé assinou uma Concordata com a Alemanha, em 1933, sendo a mesma prontamente violada pelo regime nazi.

Passado o terror do $3^{\circ}$ Reich, a Constituição de 1949 veio refundar a Alemanha, baseando-se no respeito dos direitos fundamentais ${ }^{75}$.

\footnotetext{
${ }^{72}$ Cfr. SINNER, Rudolf von - Dossiê: Religião e globalização - Estado e religiões - O exemplo da Alemanha. Civitas. V.14, no 3 (Set-Dez, 2014). Porto Alegre. p. 473.

${ }^{73}$ Cfr. ADRAGÃO, Paulo Pulido - A Liberdade Religiosa... cit., p. 186.

${ }^{74}$ Em 1871, deu-se a unificação política e administrativa da Alemanha, que passou a ser um Estado-nação.

${ }^{75}$ Cfr. ADRAGÃO, Paulo Pulido - A Liberdade Religiosa... cit., p. 186-188.
} 
Enquanto a França adota a sua laicité (fortemente laicista) e os Estados Unidos da América seguem o wall of separation - separação absoluta entre Igreja e Estado - a Alemanha é adepta do sistema de cooperação entre o Estado e a religião.

Na Alemanha, País tradicionalmente cristão, verifica-se hoje, praticamente, uma biconfessionalidade, onde a Igreja Católica Romana e as Igrejas Evangélicas (a luterana e as reformadas ou unidas) gozam de certos privilégios junto do Estado, embora não façam parte da máquina estatal. Outras confissões religiosas, mediante o preenchimento de certos requisitos, podem também assumir o estatuto de corporações de Direito Público, a fim de gozarem de certos benefícios junto do Estado, como explica Jónatas Machado (1996, p. 321): "Na Alemanha, caracterizada por um sistema de paridade entre a Igreja Católica e as Igrejas Evangélicas, prevalece um sistema bilateral assente na celebração de concordatas e acordos eclesiásticos e na consideração de algumas confissões religiosas como corporações de direito público"76.

Diferentemente das corporações de direito público comuns, que devem seguir objetivos públicos definidos por lei, as confissões religiosas que assumem tal condição, passam a possuir um status sui generis, no qual não são submetidas à supervisão estatal.

$\mathrm{Na}$ qualidade de corporações de direito público, as confissões adquirem o direito de receber impostos dos seus membros (o chamado "imposto religioso", figura típica do direito alemão) e mantêm autonomia em questões de auto-organização, criação de sub-entidades, uma pequena abertura para legislar em direito público e em direito paroquial, sobre como empregar os seus colaboradores e, ainda, no que diz respeito à automática incorporação de pessoas pertencentes ao seu quadro, quando transferidas para outro território em que também funcione a correspondente comunidade religiosa ${ }^{77}$.

Criado na segunda metade do século XIX, com o objetivo de substituir as ajudas diretas prestadas pelo Estado, o imposto religioso funciona mediante a declaração do fiel ao Fisco sobre qual a sua confissão. A partir disto, o Fisco fica responsável por recolher o imposto e, após subtrair cerca de 3 a $4 \%$ a título de despesas administrativas, transfere o valor para a respetiva igreja. Caso a pessoa mude ou deixe de ter religião, terá de informar o poder público, para desobrigar-se do pagamento do imposto.

Desde a entrada em vigor da Constituição de Weimar, em 1919, as Igrejas Católica Romana, Vétero-Católica, Evangélicas (a luterana e as reformadas ou unidas), Luterana

\footnotetext{
${ }^{76}$ Cfr. MACHADO, Jónatas Eduardo Mendes - Liberdade Religiosa numa comunidade ...cit., p. 321.

${ }^{77}$ Cfr. SINNER, Rudolf von - Dossiê: Religião e globalização...cit., p. 475.
} 
Autónoma e as Comunidades Israelitas já possuíam o status de corporação de direito público, sendo automaticamente reconhecidas.

Atualmente, cabe aos Estados federados reconhecerem, ou não, o estatuto de direito público às confissões, mediante o preenchimento de três condições, quais sejam, a solicitação formal da instituição interessada, a necessidade de ser uma comunidade religiosa e ter condições de garantir, em função do número de seus membros, a durabilidade da sua existência ${ }^{78}$.

Ressalta-se que o Islão, apesar de ser a segunda maior confissão religiosa na Alemanha, ficando atrás apenas do grupo formado pelas confissões cristãs ${ }^{79}$, teve, até agora, somente uma comunidade reconhecida como corporação de direito público, pelo Estado de Hesse, qual seja, a comunidade Ahmadiyya Muslim Jamaat ${ }^{80}$, que desde 2013 assumiu esse estatuto.

O escasso número de comunidades islâmicas inscritas como corporações de direito público, deve-se, principalmente, à falta de comprovação da pertença efetiva. Como um dos benefícios adquiridos com a inscrição é a possibilidade de receber o imposto religioso, é essencial que se tenha uma listagem atualizada, apta a comprovar a existência de membros efetivos suficientes da confissão. Todavia, a tradição muçulmana não conta com a prática do registo dos seus fiéis, o que dificulta a obtenção de um dos requisitos necessários para a inscrição.

$\mathrm{Na}$ busca de garantir plenamente a liberdade religiosa nas suas formas positiva e negativa, além da inscrição como corporações de direito público, a Alemanha oferece outras formas de apoio e cooperação às confissões, como por exemplo, a possibilidade de haver "Faculdades de Teologia confessionais nas universidades públicas, onde é feita a formação não apenas do clero das referidas igrejas, mas também de professores e professoras de ensino religioso" $"$, uma vez que, mesmo sendo de matrícula facultativa ao aluno, o ensino religioso de natureza confessional faz parte do currículo das escolas públicas e é pago pelo Estado, inclusive o ensino religioso islâmico, que já conta com alguns cursos de formação instalados.

\footnotetext{
${ }^{78}$ Cfr. HEINIG, Hans Michael - Der Körperschaftsstatus nach Art. 137 Abs. 5 S. 2 WRV, in REUTER, Astrid; KIPPENBERG, Hans G. (Coords.) - Religionskonflikte im Verfassungsstaat. Göttingen. Vandenhoeck \& Ruprecht, 2010. ISBN 978-3-525-54008-4. p. 99.

79 Vide, supra, os gráficos (figuras 3 e 4).

${ }^{80} \mathrm{Cfr}$. a lista completa de comunidades reconhecidas, por Estado, disponível em http://www.personenstandsrecht.de/PERS/DE/Themen/Informationen/religionsgemeinschaften/religionsgemeins chaften_node.html. [Consultado em 22 de abril de 2018].

${ }^{81}$ Cfr. SINNER, Rudolf von - Dossiê: Religião e globalização...cit., p. 470.
} 


\section{c) A Lei Fundamental da Alemanha e as restrições a direitos, liberdades e garantias ${ }^{82}$}

Promulgada em 23 de maio de 1949, a atual Lei Fundamental da Alemanha, ou seja, a sua Constituição, consagra-se como “a ordem fundamental jurídica da coletividade. Ela determina os princípios diretivos, segundo os quais deve formar-se a unidade política e as tarefas estatais serem exercidas. Ela regula os procedimentos de superação de conflitos no interior da coletividade. Ela ordena a organização e o procedimento de formação da unidade política e da atividade estatal. Ela cria bases e normaliza traços fundamentais da ordem jurídica global. Em tudo, ela é o plano estrutural fundamental, orientado por determinados princípios de sentido, para a configuração jurídica de uma coletividade" ${ }^{\natural 3}$.

A Constituição, no exercício da sua função, possui dois lados: um aberto e outro fechado. A abertura da Constituição visa possibilitar a construção estatal e dar vida ao procedimento decisório relativo a questões não previstas, ou apenas, parcialmente previstas. Todavia, as bases de ordem da coletividade, que incluem os direitos fundamentais, inseremse no campo fechado da Constituição, não podendo, em caso algum, ficar em aberto ${ }^{84}$.

Por tratar-se da base estrutural de toda uma sociedade, é imperativa uma correta e justa interpretação da Carta Magna, com o fim de atingir um entendimento exato, dentro de um procedimento racional e controlável, criando, assim, certeza jurídica e previsibilidade.

Ultrapassando os elementos clássicos da interpretação constitucional, formulados por Savigny, no século XIX, quais sejam, o gramatical, o lógico, o histórico e o sistemático, a interpretação tradicional agregou o elemento objetivo (vontade expressa na norma), ou o elemento subjetivo (vontade do legislador), ao aplicar os elementos clássicos no processo interpretativo 85 .

\footnotetext{
${ }^{82}$ Lei Fundamental da Alemanha (versão integral traduzida para o português). [em linha]. [Consultado em 26 de abril de 2018]. Disponível em https://www.btg-bestellservice.de/pdf/80208000.pdf.

${ }^{83}$ Cfr. HESSE, Konrad - Elementos de Direito Constitucional da República Federal da Alemanha (Grundzüge des Verfassungsrechts der Bundesrepublik Deutschland). Tradução: Luís Afonso Heck. Porto Alegre. Sergio Antonio Fabris Editor, 1998. ISBN 85-88278-05-7. p. 37.

${ }^{84}$ No tocante à referida face aberta da Lei Fundamental, a sua interpretação tem uma importância decisiva. Em tal caso, a interpretação dada pelo Tribunal Constitucional alemão somente pode converter-se em realidade se exprimir o âmago da Constituição, uma vez que, ainda que o Tribunal tenha legitimidade para determinar a obrigatoriedade do conteúdo da sua interpretação, vinculando tanto os cidadãos como os demais órgãos estatais, o TC não é superior à Constituição, devendo a esta a sua existência. Nas palavras de Hesse, "interpretação constitucional é concretização. Exatamente aquilo que, como conteúdo da Constituição, ainda não é unívoco, deve ser determinado para inclusão na 'realidade' a ser ordenada [...]. Nesse aspecto, a interpretação jurídica tem caráter criador: o conteúdo da norma interpretada conclui-se primeiro a partir da interpretação; naturalmente, ela tem também, somente nesse aspecto, caráter criador: a atividade interpretativa permanece vinculada à norma”. Cfr. HESSE, Konrad - Elementos de Direito Constitucional...cit., p. 61.

${ }^{85}$ Cfr. BULOS, Uadi Lammêngo - Curso de direito constitucional. $4^{\text {a }}$ ed. São Paulo. Saraiva, 2009. ISBN 9788502075849. p. 358.
} 
Apesar do Tribunal Constitucional se autodeclarar seguidor da interpretação tradicional, com preponderância do elemento objetivo, observa-se, em alguns casos, que o citado tribunal deixa tal regra de lado, quando assim o exigem o interesse social e o caso concreto, para fins de uma decisão mais de acordo com a realidade possível.

Para alcançar a exatidão objetivada, criando, assim, certeza jurídica e previsibilidade, devem ser seguidos alguns princípios mais concretos de interpretação da Constituição. Todavia, tais resultados não são detentores de exatidão absoluta, pois a interpretação jurídica pode manter-se imersa na ficção ou imaginação dos juristas; por isso, reconhecendo a sua limitação, é costume dizer-se, no âmbito jurídico, que diante da pretensão de uma exatidão absoluta, se alcança uma exatidão relativa, cuja razoabilidade permite afirmar certeza jurídica ${ }^{86}$.

Assim, os princípios aplicados na interpretação da Constituição são:

- Princípio da unidade da Constituição: determina que, durante a interpretação, não se deve olhar apenas para a norma individual, mas sim para a conexão sistemática na qual ela deve ser inserida;

- Princípio da concordância prática: preceitua que os bens jurídicos a serem protegidos devem ser coordenados entre si, de forma que cada um deles, individualmente, ganhe realidade. Este princípio ressalta a necessidade de observância da proporcionalidade, garantindo que a coordenação recíproca não vá além do necessário para produzir a devida concordância entre os bens jurídicos em questão; por outro lado, chama a atenção para a diferença entre "proporcionalidade" e "ponderação de bens". Enquanto na "proporcionalidade" existe uma equivalência de valor entre os bens a serem coordenados, na "ponderação" observa-se a primazia de um bem em relação a outro, ou seja, não há uma equivalência, uma ação recíproca;

- Princípio da exatidão funcional: prescreve deverem os órgãos interpretadores restringir-se às funções que lhes foram determinadas pela própria Constituição;

- Princípio do efeito integrador: estabelece que, uma vez sendo a produção e conservação da unidade política fatores de fundamental importância para a Constituição, então, a resolução de problemas jurídico-constitucionais deve, sem sombra de dúvida, privilegiar pontos de vista que levem ao efeito criador e conservador da unidade;

\footnotetext{
${ }^{86}$ Cfr. HESSE, Konrad - Elementos de Direito Constitucional.... cit., p. 65.
} 
- Princípio da força normativa da Constituição: intimamente relacionado com a "realização da Constituição", o princípio da força normativa da Constituição indica que, observando-se a vontade da Carta em ser atualizada, a resolução de problemas jurídico-constitucionais precisa de atentar nas transformações sofridas pelas possibilidades e condições históricas sob as quais tal atualização será processada, de forma a que, às normas constitucionais seja proporcionada a esperada e eficaz força, para produzir um efeito de excelência ${ }^{87}$.

Até ao momento, nesta alínea, temos falado a respeito da interpretação constitucional propriamente dita. Falemos, agora, sobre a interpretação de leis em conformidade com a Constituição.

Neste contexto, cumpre-nos lembrar as três características que compõem a utilidade dos princípios hermenêuticos referidos, ensinada por Canotilho (1998): “(a) serem um padrão que permite aferir a validade das leis, tornando inconstitucionais ou ilegais as disposições legais ou regulamentadoras ou atos que os contrariem; (b) serem auxiliares potenciais da interpretação de outras normas jurídicas; (c) terem capacidade de integração de lacunas" 88 .

Graças à ampliação da jurisdição constitucional, na Lei Fundamental alemã, fala-se da interpretação conforme a Constituição como um princípio, que está a ser utilizado na prática judicial do Tribunal Constitucional Federal, figurando na sua jurisprudência e tem vindo, progressivamente, a formar-se e organizar-se ${ }^{89}$.

De acordo com o princípio da interpretação conforme a Constituição, uma lei não deve ser considerada nula por desconformidade à Constituição, caso possa ser interpretada, de algum modo, em consonância com ela, entendendo-se que, a interpretação não se limita apenas aos pontos que admitam uma interpretação compatível com a Constituição, mas estende-se também aos pontos ambíguos ou indeterminados, que possam tornar-se determinados, em virtude dos conteúdos da Constituição.

Desta forma, para a interpretação conforme a Constituição, as normas constitucionais, além de normas de exame, tornam-se normas materiais, voltadas para a determinação do

\footnotetext{
${ }^{87}$ Ibidem.

${ }^{88}$ Apud COLOMBO, Silvana; FREITAS, Vladimir Passos de - Da Teoria do Risco Concreto à Teoria do Risco Abstrato na Sociedade Pós-industrial: um estudo da sua aplicação no âmbito do Direito Ambiental. Quaestio Iuris. vol. 08, nº 03 (2015). Rio de Janeiro. p. 1903.

${ }^{89}$ Cfr. HESSE, Konrad - Elementos de Direito Constitucional... cit., p. 70-71.
} 
conteúdo de leis ordinárias em causa. Ressalta-se que, apesar de não ser decisiva, a vontade do legislador deve ser mantida, o máximo possível.

Tal princípio toma por base dois parâmetros: a lei a ser examinada e o conteúdo da Constituição, à qual a lei deve ser aferida. Requer-se, aqui, tanto interpretação da lei como da Constituição ${ }^{90}$.

Como consequência da necessidade de manter a unidade da ordem jurídica, as leis promulgadas durante a vigência da atual Lei Fundamental devem ser interpretadas de acordo com esta, assim como as leis aprovadas na vigência de qualquer Constituição anterior devem ser ajustadas à nova ordem constitucional.

A Lei Fundamental define, nos seus artigos $93^{\circ}$ e $100^{\circ 91}$, respetivamente, as funções do Tribunal Constitucional Federal e as regras para o controle de normas, tendo em consideração casos concretos, devendo o TC restringir-se a seguir tal determinação constitucional, uma vez que a presunção de constitucionalidade pertence ao legislador democrático e é vetado ao tribunal tomar para si tal prerrogativa, causando uma alteração das funções previamente atribuídas jurídico-constitucionalmente, como preconiza o já mencionado princípio da exatidão funcional.

\footnotetext{
${ }^{90}$ Segundo Hesse, “A 'interpretação conforme a Constituição' coloca não somente a questão sobre o conteúdo da lei a ser examinada, mas também a questão sobre o conteúdo da Constituição, à qual a lei deve ser aferida. Ela requer, por conseguinte, tanto interpretação da lei como interpretação da Constituição. Já que a conexão jurídicomaterial, como a jurídico-funcional, indicam na direção de uma manutenção da lei, a interpretação conforme a Constituição irá interpretar a norma constitucional a ser interpretada, na medida do possível, naquele sentido no qual o legislador a concretizou. Interpretação conforme à Constituição de leis é, por conseguinte, em sua repercussão sobre a interpretação constitucional, interpretação conforme à lei da Constituição. Ela mostra-se, nisto, um outro - por se assim dizer, indireto - princípio de interpretação constitucional pelos tribunais. Simultaneamente, esse efeito confirma a correlação estreita entre Constituição e lei e, com isso, a ideia da unidade da ordem jurídica". Cfr. HESSE, Konrad - Elementos de Direito Constitucional... cit., p. 75.

${ }^{91}$ Cfr. Lei Fundamental da Alemanha...cit.:

"Artigo 93 [Competência do Tribunal Constitucional Federal]

(1) O Tribunal Constitucional Federal decide:

(...)

2. No caso de divergências ou dúvidas a respeito da compatibilidade formal e material da legislação federal ou estadual com a presente Lei Fundamental ou da compatibilidade da legislação estadual com outras leis federais, quando o solicitem o Governo Federal, o governo de um Estado ou um quarto dos membros do Parlamento Federal;

(...)

Artigo $100^{\circ}$ [Controle concreto de normas]

(1) Quando um tribunal considerar uma lei, de cuja validade dependa a decisão, como inconstitucional, ele terá de suspender o processo e submeter a questão à decisão do tribunal estadual competente em assuntos constitucionais, quando se tratar de violação da constituição de um Estado, ou à decisão do Tribunal Constitucional Federal, quando se tratar da violação desta Lei Fundamental. Isto também é aplicável, quando se tratar da violação desta Lei Fundamental pela legislação estadual ou da incompatibilidade de uma lei estadual com uma lei federal.

(...)"
} 
No seguimento da explanação sobre as funções do Tribunal Constitucional, aproveitamos o ensejo para iniciarmos um breve comentário sobre os direitos fundamentais (direitos, liberdades e garantias) no âmbito da Constituição alemã, uma vez que o julgado, objeto deste trabalho, trata da discussão, pelo TC, sobre um direito fundamental, qual seja, a liberdade religiosa.

A Lei Fundamental da Alemanha, logo no seu Título I, já trata dos direitos fundamentais, de forma a definir o conceito desses direitos, como sendo, simplesmente, aqueles que a Constituição define como fundamentais. Todavia, esse é um conceito meramente formal, mostrando-se insuficiente para cobrir o significado material dos direitos fundamentais.

Assim, também fora do seu primeiro título, a Constituição alemã tutela direitos que, pela sua peculiaridade, se inserem no catálogo de direitos fundamentais, como por exemplo, os direitos previstos no art. $33^{\circ}$, alíneas 1 a 3 da Lei Fundamental, que garantem a igualdade de direitos cívicos e de ingresso ao serviço público ${ }^{92}$.

Voltando-nos para o direito fundamental em causa neste trabalho, encontramos a liberdade religiosa reconhecida no art. $4^{\circ}$ da Constituição da Alemanha ${ }^{93}$, firmando-se como direito inviolável.

Uma vez que a Lei Fundamental reconhece a liberdade religiosa, bem como confirma a neutralidade do Estado, torna-se claro que a Constituição visa incentivar e favorecer a pluralidade potencial ou pluralismo ${ }^{94}$, permitindo uma discussão rica e instrutiva no seio da sociedade. Quanto a isto, Konrad Hesse (1998, p. 299) anota que "nesse ponto, a liberdade de fé e confissão serve não só à finalidade de impedir intervenções estatais e abusos eclesiásticos;

\footnotetext{
${ }^{92}$ Cfr. Lei Fundamental da Alemanha... cit.:

“Artigo $33^{\circ}$ [Igualdade de direitos cívicos dos alemães - Serviço público]

(1) Todos os alemães têm, em qualquer Estado, os mesmos direitos e deveres cívicos.

(2) Todos os alemães têm igual acesso a qualquer cargo público, de acordo com sua aptidão, capacidade e desempenho profissional.

(3) O gozo dos direitos civis e cívicos, a admissão a cargos públicos, bem como os direitos adquiridos no serviço público são independentes da confissão religiosa. Ninguém poderá sofrer discriminação por professar ou deixar de professar determinada religião ou ideologia.

(...)"

${ }^{93}$ Cfr. Lei Fundamental da Alemanha... cit.:

"Artigo $4^{\circ}$ [Liberdade de crença e de consciência]

(1) A liberdade de crença, de consciência e a liberdade de confissão religiosa e ideológica são invioláveis.

(2) É assegurado o livre exercício da religião.

(3) Ninguém poderá ser obrigado, contra a sua consciência, ao serviço militar com armas. A matéria será regulamentada por uma lei federal".

${ }^{94}$ Cumpre-nos, aqui, diferenciar "pluralidade potencial" de "pluralidade efetiva" no âmbito da liberdade religiosa. Enquanto a "pluralidade efetiva" consiste na real existência de diversas confissões numa dada sociedade, a "pluralidade potencial", ou o "pluralismo", consiste na possibilidade ou na liberdade de haver várias religiões diferentes num determinado País ou região. O Estado há de ter como objeto de proteção este segundo tipo de pluralidade, a "pluralidade potencial".
} 
mas ela é, simultaneamente, garantida por causa de sua atualização, e essa garantia não se restringe a uma fé ou uma ideologia determinada, porque elas, somente na sua pluralidade, podem atuar como fatores do processo político e espiritual livre, que é importante para a Constituição. Por causa disso, fé e confissão não são afastadas para um âmbito do não-essencial para a ordem constitucional e as forças que sustentam aquele processo são valorizadas positivamente pela Constituição" $"$.

Ressalta-se, entretanto, que, visando proteger a ordem fundamental liberal democrática, a fim de evitar que as bases da Constituição sejam feridas ou eliminadas, é necessário a fiscalização do exercício dos direitos fundamentais.

A limitação dos direitos fundamentais constitucionalmente fixados só pode ocorrer por meio da própria Constituição ${ }^{96}$. O art. $18^{\circ}$ da Lei fundamental é um exemplo dessa limitação, que enumera casos onde o abuso de certos direitos fundamentais pode levar à sua perda, mediante decisão do Tribunal Constitucional ${ }^{97}$.

Sem entrar no âmago da questão da limitação, mas fazendo uma breve explanação para atender ao interesse deste estudo, pode-se dizer que a possibilidade de limitação ou restrição dos direitos fundamentais diferencia-se de acordo com o grau de abertura que a Constituição definiu para cada direito fundamental, ou seja, varia em função do "tipo de reserva" que a Constituição atribuiu a cada direito fundamental. Observa-se que um direito sem reservas, digase, com um grau baixíssimo de abertura, é menos vulnerável às restrições, nomeadamente, as restrições por via da lei ordinária.

Como explica Jorge Novais (2003, p. 163), é possível definir o grau de abertura de cada direito, partindo-se de uma diferenciação hermenêutica entre direitos fundamentais mais ou menos materialmente determinados e direitos fundamentais mais ou menos juridicamente determinados ${ }^{98}$.

\footnotetext{
${ }^{95}$ Cfr. HESSE, Konrad - Elementos de Direito Constitucional... cit., p. 299.

${ }^{96}$ Segundo Hesse, "como as garantias de liberdade jurídico-fundamentais são fundamentadas pela Constituição, assim também podem os limites dessas garantias encontrar sua base somente na Constituição". Cfr. HESSE -

Elementos de Direito Constitucional...cit., p. 250.

${ }^{97}$ Cfr. Lei Fundamental da Alemanha... cit.:

"Artigo $18^{\circ}$ [Perda dos direitos fundamentais]

Quem, para combater a ordem fundamental livre e democrática, abusar da liberdade de expressar a opinião, particularmente da liberdade de imprensa (artigo 5 \$1), da liberdade de ensino (artigo 5 \$3), da liberdade de reunião (artigo 8), da liberdade de associação (artigo 9), do sigilo da correspondência, das comunicações postais e das telecomunicações (artigo 10), do direito de propriedade (artigo 14) ou do direito de asilo (artigo 16 \$2), perde estes direitos fundamentais. Cabe ao Tribunal Constitucional Federal pronunciar-se sobre a perda dos direitos e fixar a sua extensão”.

${ }^{98}$ Cfr. NOVAIS, Jorge Reis - As restrições aos direitos fundamentais não expressamente autorizadas pela Constituição. Coimbra. Coimbra Editora, 2003. ISBN 972-32-1177-7. p. 163.
} 
Direitos como a liberdade de crença, a liberdade artística, a liberdade científica e de consciência são materialmente determinados, tendo assim, uma existência independente do Direito constituído. Tais liberdades fundam-se na natureza humana, localizam-se numa esfera pré-positiva. Assim, cabe à Constituição tão somente reconhecê-las como manifestações próprias da liberdade humana.

Para além da expressa limitação constitucional (limites explícitos), temos de levar em conta um outro método de controlo que, apesar de mais subtil, não deixa de existir. Trata-se do limite imposto pelas regras de convivência em sociedade ou, como reza o dito popular "o direito de um termina quando o direito do outro começa". A jusfundamentalização da liberdade geral não contém em si uma permissão para que cada um faça o que quiser.

Esta regra social que pratica a "limitação", implícita no supracitado dito popular, pode ser confirmada pela doutrina dos limites imanentes dos direitos fundamentais (immanenten Grundrechtsgrenzen). Tal doutrina foi recuperada, no início da década de 1950, pela jurisprudência administrativa e constitucional alemã e, a partir daí, ganhou sucesso e projeção, atravessando fronteiras. Partindo do princípio de que os direitos fundamentais apresentam uma limitação intrínseca, dir-se-ia que, numa comunidade baseada na democracia e igualdade, as liberdades reconhecidas a cada cidadão, já na origem e consagração constitucional, possuem uma limitação imanente, dada a necessidade de conciliá-las entre si e os seus detentores.

Desta forma, observamos que os limites podem ser explícitos, quando determinados na letra da lei, ou podem ser imanentes, quando são materiais e resultam da natureza humana.

A Lei Fundamental da Alemanha aspira a proteger e conservar não apenas a existência dos direitos fundamentais, mas também a sua plena eficácia. Nesse sentido, o art. $19^{\circ}$ da Carta Magna $^{99}$ preconiza a proteção contra a "escavação interna". Segundo Hesse (1998, p. 264), escavação interna significa o abuso de reservas legais e faz com que certos direitos

\footnotetext{
${ }^{99}$ Cfr. Lei Fundamental da Alemanha... cit.:

"Artigo $19^{\circ}$ [Restrição dos direitos fundamentais - Via judicial]

(1) Na medida em que, segundo esta Lei Fundamental, um direito fundamental possa ser restringido por lei ou em virtude de lei, essa lei tem de ser genérica e não limitada a um caso particular. Além disso, a lei terá de citar o direito fundamental em questão, indicando o artigo correspondente.

(2) Em nenhum caso, um direito fundamental poderá ser violado em sua essência.

(3) Os direitos fundamentais também são válidos para as pessoas jurídicas sediadas no País, conquanto, pela sua essência, sejam aplicáveis às mesmas.

(4) Toda pessoa, cujos direitos forem violados pelo poder público, poderá recorrer à via judicial. Se não se justificar outra jurisdição, a via judicial será a dos tribunais ordinários. Mantém-se inalterado o artigo $10 \$ 2$, segunda proposição".
} 
fundamentais, apesar de ainda estarem formalmente em vigor, já não produzam efeitos e deixem de cumprir a sua função objetiva ${ }^{100}$.

Fazendo um breve paralelo, temos o artigo $18^{\circ}$ da Constituição portuguesa, onde os direitos fundamentais, assim como na Alemanha, são protegidos, estando qualquer restrição condicionada à previsão constitucional ${ }^{101}$. Canotilho e Vital Moreira (2007, p. 379-396) $)^{102}$ ressaltam que, para ser válida uma restrição a um direito fundamental é necessária a verificação cumulativa de todos os pressupostos materiais vislumbrados nos números 2 e 3 do artigo $18^{\circ}$, bem como dos requisitos quanto ao caráter da própria lei. Jorge Miranda e Rui Medeiros (2010, p. 316-317, 346-353) ${ }^{103}$ nomeiam de "princípio do caráter restritivo das restrições" o elenco dos requisitos necessários para a viabilidade de uma lei restritiva de direitos fundamentais, devendo o mesmo configurar a cumulação dos pressupostos referidos.

Dentro de todas as possibilidades vislumbradas para a restrição a direitos fundamentais, deve-se, ainda, observar uma questão de extrema relevância, qual seja, que uma restrição para ser legítima, há de ser "necessária”, não bastando que seja apenas "razoável”"104.

Passados em revista alguns conceitos técnico-jurídicos, ficamos em melhores condições para uma análise crítica da decisão do Acórdão do Tribunal Constitucional alemão de 27 de janeiro de 2015 .

\footnotetext{
${ }^{100}$ Cfr. HESSE - Elementos de Direito Constitucional...cit., p. 264.

${ }^{101}$ Cfr. Constituição da República Portuguesa de 1976. Assembleia da República. [em linha]. [Consultado em 25 de maio de 2018]. Disponível em

https://www.parlamento.pt/Legislacao/Paginas/ConstituicaoRepublicaPortuguesa.aspx.:

"Artigo $18^{\circ}$ [Força jurídica]

1. Os preceitos constitucionais respeitantes aos direitos, liberdades e garantias são directamente aplicáveis e vinculam as entidades públicas e privadas.

2. A lei só pode restringir os direitos, liberdades e garantias nos casos expressamente previstos na Constituição, devendo as restrições limitar-se ao necessário para salvaguardar outros direitos ou interesses constitucionalmente protegidos.

3. As leis restritivas de direitos, liberdades e garantias têm de revestir carácter geral e abstracto e não podem ter efeito retroactivo nem diminuir a extensão e o alcance do conteúdo essencial dos preceitos constitucionais." ${ }^{102}$ Cfr. CANOTILHO, J. J. Gomes; MOREIRA, Vital - Constituição da República Portuguesa Anotada. Volume I. $4^{a}$ edição revista. Coimbra. Editora Coimbra, 2007. ISBN 978-972-32-1462-8. p. 379-396.

${ }^{103}$ Cfr. MIRANDA, Jorge; MEDEIROS, Rui - Constituição Portuguesa Anotada. Tomo I. $2^{\mathrm{a}}$ edição, revista, actualizada e ampliada. Coimbra. Coimbra Editora, 2010. ISBN 978-972-32-1822-0. p. 316-317; 346-353. ${ }^{104}$ Cfr. EVANS, Malcolm D. - Manual on the Wearing of Religious Symbols in Public Areas. V.21, $\mathrm{n}^{\circ} 2$ (2010). Security and Human Rights. p. 87.
} 


\section{d) A decisão do Acórdão do Tribunal Constitucional alemão de 27 de janeiro de 2015 - análise crítica}

A questão do litígio em análise incidiu sobre a Lei Educacional do Estado da Renânia do Norte-Vestfália, notadamente sobre seu $\$ 57$, secção $4^{105}$, que dizia, na sentença 1 , que os professores não poderiam, publicamente, expressar pontos de vista políticos, religiosos, ideológicos ou similares que pudessem interferir ou pôr em causa a neutralidade do Estado, bem como a liberdade religiosa de pais e alunos, ou perturbar a paz política, religiosa e ideológica na escola; na sentença 2, dizia que era proibido adotar uma conduta capaz de criar a impressão, entre pais e alunos, de o professor estar a fazer apologia contra a dignidade humana, a igualdade de tratamento, as liberdades fundamentais ou a liberdade democrática; e, finalmente, na sentença 3, declarava que expressar tradições educacionais e culturais cristãs e ocidentais não contrariava o disposto na sentença 1. Ressalta-se que esta mesma Lei Educacional, apresentava um $\S 58$ que, na sentença $2^{106}$ determinava serem as disposições da presente lei aplicáveis aos demais funcionários da educação, incluindo o pessoal socioeducativo, empregado pelo Estado.

Segundo a interpretação da Lei Educacional da Renânia do Norte-Vestfália pelo Estado em causa, o uso do hijab pelas professoras e demais funcionárias do corpo socioeducativo gerava um risco abstrato contra a neutralidade do Estado e contra a liberdade religiosa dos pais e alunos, uma vez que os discentes eram expostos à visão de um objeto de cunho religioso diferente das tradições cristãs e ocidentais. Ainda segundo o Estado da Renânia, colocou-se em risco o direito dos pais criarem os seus filhos conforme a sua crença religiosa, ou sem qualquer crença, enfatizando ser papel da função educativa, que o Estado possui em conjunto com os pais, impedir o acesso das crianças à visão de símbolos e objetos de conotação religiosa.

\footnotetext{
${ }^{105}$ Cfr., no original, acórdão do Tribunal Constitucional alemão (BvR 471/10 e BvR 1181/10)... cit., §2:

“(1)Lehrerinnen und Lehrer dürfen in der Schule keine politischen, religiösen, weltanschaulichen oder ähnliche äußere Bekundungen abgeben, die geeignet sind, die Neutralität des Landes gegenüber Schülerinnen und Schülern sowie Eltern oder den politischen, religiösen oder weltanschaulichen Schulfrieden zu gefährden oder zu stören. (2)Insbesondere ist ein äußeres Verhalten unzulässig, welches bei Schülerinnen und Schülern oder den Eltern den Eindruck hervorrufen kann, dass eine Lehrerin oder ein Lehrer gegen die Menschenwürde, die Gleichberechtigung nach Artikel 3 des Grundgesetzes, die Freiheitsgrundrechte oder die freiheitlichdemokratische Grundordnung auftritt. (3)Die Wahrnehmung des Erziehungsauftrags nach Artikel 7 und 12 Abs. 6 der Verfassung des Landes Nordrhein-Westfalen und die entsprechende Darstellung christlicher und abendländischer Bildungs- und Kulturwerte oder Traditionen widerspricht nicht dem Verhaltensgebot nach Satz 1".

${ }^{106}$ Cfr., no original, acórdão do Tribunal Constitucional alemão (BvR 471/10 e BvR 1181/10)... cit., §5:

"(1)Sonstige im Landesdienst stehende pädagogische und sozialpädagogische Mitarbeiterinnen und Mitarbeiter wirken bei der Bildungs- und Erziehungsarbeit mit. (2)\$57 Abs. 4 und 6 gilt entsprechend”.
} 
Em face dos recursos interpostos pelas demandantes contra as decisões dos tribunais do trabalho, o Tribunal Constitucional alemão julgou que as referidas decisões violaram os direitos fundamentais das profissionais da educação, ferindo os preceitos do art. $4^{\circ}$, sentenças 1 e 2 , da Lei Fundamental da Alemanha ${ }^{107}$, que protegem a liberdade de crença e de consciência, assegurando o livre exercício da religião.

Neste sentido, o TC determinou deverem as decisões do Tribunal Superior do Trabalho e do Tribunal Federal do Trabalho serem revertidas, de forma que fosse dada uma interpretação restritiva e conforme a Constituição às sentenças 1 e 2, secção 4, do §57, da Lei Educacional da Renânia do Norte-Vestfália, bem como declarou a inconstitucionalidade e consequente nulidade da sentença 3, secção 4, do §57, da mesma Lei Educacional, visto ser discriminatória a permissão apenas da expressão de tradições educacionais e culturais cristãs. Ressalta-se que o TC vinculou as decisões futuras dos tribunais ordinários, ordenando que estes façam uma interpretação da lei conforme a Constituição.

Para chegar à decisão do acórdão de 2015, objeto de estudo deste trabalho, o Tribunal Constitucional fundou-se em dois fortes argumentos: (1) a impossibilidade de se restringir um direito fundamental com base, apenas, num risco abstrato; (2) a necessidade de se interpretar a lei conforme a Constituição.

Como foi visto no Capítulo II $^{108}$, o mesmo Tribunal Constitucional alemão teve um entendimento bastante controverso, no ano de 2003, ao julgar o caso de Fereshta Ludin, envolto nas mesmas questões suscitadas no julgado de 2015. Naquele julgamento, o TC deu ganho de causa à Sra. Ludin, fundamentando a sua decisão unicamente no facto de que o Estado de BadeVutemberga não possuía legislação a respeito da utilização de símbolos religiosos pelos professores de escolas públicas, não podendo, por esse motivo, proibi-los. Nessa primeira sentença $^{109}$, como se referiu supra, o tribunal, além de defender o argumento de que um risco abstrato seria suficiente para justificar a restrição ao direito fundamental da professora, também entendeu que o direito à liberdade religiosa negativa de pais e alunos se sobrepõe ao direito à liberdade religiosa positiva dos professores, bem como que a neutralidade do Estado consiste,

\footnotetext{
${ }^{107}$ Cfr. Lei Fundamental da Alemanha... cit.: "Artigo $4^{\circ}$ [Liberdade de crença e de consciência]

(1) A liberdade de crença, de consciência e a liberdade de confissão religiosa e ideológica são invioláveis.

(2) É assegurado o livre exercício da religião".

108 Ver Capítulo II, páginas 26-27 e nota de rodapé 23.

109 Teor integral do acórdão do Tribunal Constitucional alemão (BvR 1436/02), de 24 de setembro de 2003 (original em alemão e versão traduzida para o inglês). [em linha]. [Consultado em 26 de abril de 2018]. Disponível em http://www.bverfg.de/e/rs20030924_2bvr143602en.html.
} 
inclusivé, em poupar os alunos à visão de símbolos e objetos de conotação religiosa diferentes da tradição alemã e em limitar o direito fundamental dos seus professores.

O tribunal induziu, em 2003, o Estado de Bade-Vutemberga a legislar no sentido de restringir a utilização de símbolos religiosos pelos professores, como também influenciou outros Estados a legislarem contrariamente à liberdade religiosa, restringindo a utilização de símbolos religiosos pelo seu pessoal docente e afins, o que fere a Lei Fundamental, notadamente no art. $4^{\text {o }}$, sentenças 1 e 2 , que declaram a liberdade religiosa de todos os indivíduos. O objetivo então postulado pelo tribunal era o de dar liberdade aos Estados para prevenir uma manifestação excessiva da crescente pluralidade existente na sociedade, notadamente, no âmbito religioso.

Constatamos, ainda, que o tribunal de 2003, cometeu outro atentado à Lei Fundamental, uma vez que não observou o princípio da concordância prática, sobrepondo o direito à liberdade religiosa negativa de pais e alunos ao direito à liberdade religiosa positiva da professora, em clara e errônea ponderação de bens que, na realidade, são equivalentes e de igual valor.

À época do acórdão expedido no caso Ludin, foi publicado um artigo acerca do caso, por P.H. Coetzee e A.P.J. Roux (2004) ${ }^{110}$, integrantes do Departamento de Filosofia da Universidade da África do Sul, onde os mesmos defenderam a liberdade religiosa e o uso do véu islâmico, baseados na teoria da filósofa sul africana Denise Meyerson (1997) ${ }^{111}$, fundamentada na ideia rawlsiana de razão pública. Segundo o estudo publicado, as negociações para o convívio em sociedade sempre geram algum prejuízo. Todavia, tais danos precisam de ser analisados pelo chamado Princípio do Prejuízo, onde encontramos uma divisão em prejuízos neutros e não neutros.

O prejuízo neutro seria aquele que, apesar de gerar um dano ao interessado, não interfere na sua essência, não atinge uma parte central da sua vida, podendo ser aceite por todas as pessoas razoáveis e ser, assim, objeto de ação do Estado. O prejuízo não neutro emergiria de uma intratável disputa de crenças, a qual não poderia ser julgada pelos cânones da razão pública comum e não teria chance de ser aceite por todas as pessoas razoáveis. As disputas de âmbito religioso seriam intratáveis, neste sentido. Concretizando, a crença de que uma mulher muçulmana sem o seu véu, está nua diante do mundo, ofendendo o Profeta Maomé com a sua imoralidade, seria exatamente deste tipo. A crença e a sua manifestação constituiriam, assim,

\footnotetext{
${ }^{110}$ Cfr. COETZEE, P.H.; ROUX, A.P.J. - Ludin's Kopftuch/(headdress): A problem of religious freedom in German schools. Koers: Bulletin for Christian Scholarship (2004). [em linha]. [Consultado em 02 de maio 2017]. Disponível em http://www.koersjournal.org.za/index.php/koers.

${ }^{111}$ MEYERSON, D. - Rights Limited: Freedom of Expression, Religion and the South African Constitution. Cape Town. Juta, 1997. ISBN 9780702143960.
} 
um dano não neutro. Desta forma, quando se trata de um prejuízo não neutro, o Estado não poderia intervir, impondo esse dano ao potencial prejudicado.

Abordamos, aqui, a Teoria do Prejuízo, de Meyerson (1997), não obstante esta se basear na ideia rawlsiana de razão pública, pela qual a religião não faz parte da esfera pública, ideia com a qual não concordamos. A nossa valorização da teoria apresentada não reside nos fundamentos rawlsianos, uma vez que entendemos que a religião tem lugar no espaço público, no sentido de o Estado dever garantir o seu livre exercício e proteger a pluralidade potencial, mas mencionámos a Teoria do Prejuízo, dada a sua possibilidade de adaptação ao universo da neutralidade-colaboração (apresentado no Capítulo III), podendo, então, contribuir, efetivamente, para a defesa da liberdade religiosa.

Desta forma, entendemos que poder-se-ia aplicar aqui uma teoria do prejuízo, em que o prejuízo não neutro fosse evitado, não pela inércia ou pela impossibilidade do Estado de agir sobre disputas de crenças, mas, pelo contrário, em função do dever do Estado de proteger os direitos fundamentais dos indivíduos, de forma a garantir o livre exercício da liberdade religiosa e a observância do pluralismo.

Finalizando a referência feita ao julgado de 2003, percebemos, claramente, que, em 2015, o Tribunal Constitucional alemão corrigiu o erro cometido em 2003 e exerceu o devido controle constitucional sobre as consequências do movimento legislativo ocorrido em vários Estados da Alemanha, declarando que o direito fundamental à liberdade religiosa dos professores não pode ser restringido com fundamento num risco meramente abstrato de violação de outras liberdade e princípios; que a liberdade religiosa negativa de pais e alunos não pode sobrepor-se à liberdade religiosa positiva dos professores e, finalmente, que faz parte da função educativa do Estado promover o conhecimento sobre as diversas formas de viver e de ver o mundo, existentes numa sociedade democrática.

No nosso ponto de vista, em 2015, o TC apurou o seu entendimento relativamente ao exercício da liberdade religiosa pelos professores das escolas públicas, compreendendo, conforme exposto no $\S 80$ do Acórdão, que "os Acórdãos dos tribunais do trabalho emitidos nos processos iniciais baseiam-se em disposições estatutárias que exigem uma interpretação restritiva em conformidade com a Constituição".

"Esses julgamentos - continua a sentença em análise - não atendem aos requisitos de tal interpretação. A proibição da expressão da crença religiosa por aparência exterior, com base num simples perigo abstrato para a paz na escola ou para a neutralidade do Estado não é, em caso algum, apropriada e é, portanto, desproporcionada, à luz da liberdade do pessoal educativo 
de expressar a sua fé e professar uma crença, se a expressão dessa crença puder ser atribuída, de maneira plausível, a um dever religioso percebido como imperativo. Em vez disso, é necessário um perigo suficientemente concreto".

"De acordo com o direito constitucional - conclui o aresto - tal proibição que se estende sobre uma região ou, possivelmente, sobre todo um Estado Federado só é possível, no que diz respeito às escolas públicas interdenominacionais, se houver um perigo suficientemente concreto para os interesses legais acima mencionados em toda a área a que se aplica a proibição"112.

No excerto supratranscrito, podemos ver a aplicação de dois princípios de interpretação: o princípio da interpretação conforme a Constituição (relativamente à interpretação da Lei Educacional da Renânia do Norte-Vestfália face à Lei Fundamental) e o princípio da concordância prática (relativamente à interpretação da Constituição propriamente dita).

Como foi estudado na alínea c) deste Capítulo, o princípio da interpretação conforme a Constituição preconiza que uma norma só deve ser considerada nula quando não se consiga, de modo algum, interpretá-la em consonância com a Constituição. Um ponto relevante sobre o princípio da interpretação conforme a Constituição é a condição de que se respeite e preserve ao máximo a vontade do legislador, mantendo a lei o mais próxima possível da sua versão original.

O que vemos na exegese das sentenças 1 e 2, do §57, da Lei Educacional do Estado da Renânia do Norte-Vestfália, é a possiblidade de se realizar uma interpretação em plena consonância com a Lei Fundamental. Para tal acontecer, basta que o Estado, a autoridade da Administração Escolar no caso em foco, entenda que, o facto de uma professora usar o hijab não produz um risco concreto, ou seja, não é capaz de interferir ou pôr em causa a neutralidade do Estado, nem a liberdade religiosa de pais e alunos, nem a paz política, religiosa e ideológica

\footnotetext{
${ }^{112}$ Cfr., no original, acórdão do Tribunal Constitucional alemão (BvR 471/10 e BvR 1181/10)... cit., §80: “Die in den Ausgangsverfahren ergangenen Urteile der Arbeitsgerichte beruhen auf einer gesetzlichen Grundlage, die der einschränkenden verfassungskonformen Auslegung bedarf. Deren Anforderungen genügen die Urteile nicht. Ein Verbot religiöser Bekundungen durch das äußere Erscheinungsbild, das bereits die abstrakte Gefahr einer Beeinträchtigung des Schulfriedens oder der staatlichen Neutralität ausreichen lässt, ist im Blick auf die Glaubens- und Bekenntnisfreiheit der Pädagogen jedenfalls unangemessen und damit unverhältnismäßig, wenn die Bekundung nachvollziehbar auf ein als verpflichtend empfundenes religiöses Gebot zurückführbar ist. Erforderlich ist vielmehr eine hinreichend konkrete Gefahr. Eine entsprechende gebietsbezogene, möglicherweise auch landesweite Untersagung kommt von Verfassungs wegen für öffentliche bekenntnisoffene Gemeinschaftsschulen nur dann in Betracht, wenn eine hinreichend konkrete Gefahr für die genannten Schutzgüter im gesamten Geltungsbereich der Untersa gung besteht".
} 
na escola e, muito menos, visa fazer uma apologia contra a dignidade humana, a igualdade de tratamento, as liberdades fundamentais ou a liberdade democrática.

Seguindo o princípio da interpretação conforme a Constituição, interpreta-se as sentenças 1 e 2, secção 4, do §57, da referida Lei Educacional, entendendo-se que a utilização do hijab por uma professora, significa, tão somente, que essa profissional está a exercer o seu direito fundamental de liberdade religiosa, plenamente protegido pelo art. $4^{\circ}$ da Lei Fundamental alemã.

Com efeito, vimos que, no julgado em questão, o Tribunal Constitucional preservou as sentenças 1 e 2, secção 4, do §57, da Lei Educacional da Renânia do Norte-Vestfália, apenas restringindo a sua interpretação no sentido de não proibir aqui o uso do véu, pois, como destaca o $§ 117$ do Acórdão, noutros casos, pode acontecer que uma limitação normativa venha a ser necessária $^{113}$.

A mesma sorte não teve a sentença 3, secção 4, do §57, da mesma Lei Educacional da Renânia do Norte-Vestfália, pois declarava que apenas a expressão de tradições educacionais e culturais cristãs e ocidentais não poria em causa a neutralidade do Estado, nem a liberdade religiosa de pais e alunos, nem tampouco a paz política, religiosa e ideológica na escola.

Tal sentença 3, contrariava cabalmente o art. $19^{\circ}$, sentença 1, da Lei Fundamental ${ }^{114}$, que exclui a restrição concreta de direitos fundamentais. Desta forma, não restou outra

\footnotetext{
${ }^{113}$ Cfr., no original, acórdão do Tribunal Constitucional alemão (BvR 471/10 e BvR 1181/10)... cit., §117: “Eine einschränkende Auslegung des $\$ 57$ Abs. 4 Satz 1 SchulG NW ist möglich und von Verfassungs wegen geboten. Sie dient der Vermeidung einer Normverwerfung und ist damit dem Gesichtspunkt der größtmöglichen Schonung der Gesetzgebung geschuldet. Sie nimmt Rücksicht darauf, dass die Norm auch andere Anwendungsbereiche hat, die sich von der hier vorliegenden Fallgestaltung unterscheiden. Dabei kann es sich etwa um verbale Äußerungen und ein offen werbendes Verhalten handeln. Hier kann die Untersagungsvorschrift auch in einer Interpretation, die schon die abstrakte Gefahr erfasst, ihre Bedeutung haben. Der einschränkenden Auslegung steht nicht entgegen, dass dem Gesetzgeber entstehungsgeschichtlich ein Kopftuchverbot als typischer Anwendungsfall der Vorschrift vorgeschwebt hat. Der Norm wird lediglich ein weniger weit reichender Anwendungsbereich zuerkannt". Tradução pessoal: "Uma interpretação restritiva do § $57 \mathrm{sec}$. 4, sentença 1, SchulG NW, é possível e ordenada pela Constituição. Ela serve para evitar a anulação da lei e, portanto, é necessária do ponto de vista da preservação da legislação na medida do possível. Respeita o fato de que a norma tem outras aplicações que divergem do caso em questão. Estes podem envolver expressões verbais, por exemplo, ou conduta publicamente aberta. Em tais casos, a proibição também pode ter significado em uma interpretação que inclui até mesmo um perigo abstrato. Não se opõe a esta interpretação restritiva que, na história legislativa, o legislador considerou a proibição de usar um véu como uma aplicação típica da provisão. A norma é meramente atribuida a uma aplicação menos abrangente".

${ }^{114}$ Cfr. Lei Fundamental da Alemanha... cit.:

"Artigo $19^{\circ}$ [Restrição dos direitos fundamentais - Via judicial] (já reproduzido supra):

(1) Na medida em que, segundo esta Lei Fundamental, um direito fundamental possa ser restringido por lei ou em virtude de lei, essa lei tem de ser genérica e não limitada a um caso particular. Além disso, a lei terá de citar o direito fundamental em questão, indicando o artigo correspondente.

(2) Em nenhum caso, um direito fundamental poderá ser violado em sua essência.

(3) Os direitos fundamentais também são válidos para as pessoas jurídicas sediadas no País, conquanto, pela sua essência, sejam aplicáveis às mesmas".
} 
alternativa ao Tribunal Constitucional, senão declarar a nulidade da aludida sentença 3, secção 4, do §57, da dita Lei Educacional, uma vez que o dispositivo em causa não poderia ser, de modo algum, adequado a uma interpretação em conformidade com a Constituição.

Em relação à utilização do princípio da concordância prática, pelo TC alemão ${ }^{115}$, notase que o tribunal ressaltou ser desproporcionada a proibição da expressão da crença pela aparência exterior, com base num mero risco abstrato de violação de outros direitos e princípios, à luz do direito da liberdade religiosa do pessoal educativo. Como explicado na alínea c) deste trabalho, ao interpretar-se a Constituição deve proceder-se à coordenação entre os bens protegidos, observando a proporcionalidade para garantir a produção da devida concordância entre os mesmos.

O julgado em questão trata de liberdade religiosa, tanto de pais e alunos (liberdade religiosa negativa), como do pessoal educativo (liberdade religiosa positiva). Desta forma, observando-se a necessidade de coordenar bens jurídicos equivalentes e de igual valor, utilizouse o critério da proporcionalidade, de modo a não permitir a sobreposição de um direito em relação ao outro, personificada na restrição da liberdade religiosa positiva das educadoras, uma vez que, como bem foi lembrado pelo próprio tribunal, a Constituição não garante a ninguém o direito de "não ver" a expressão das convicções religiosas alheias ${ }^{116}$.

Deve-se, ainda, atentar para a diferença entre símbolos religiosos pessoais e símbolos religiosos institucionais. Como ensina Rafael Palomino (2016, p. 31-32) ${ }^{117}$, o símbolo pessoal é aquele que se incorpora nas pessoas, na qualidade do vestuário, traje ou adorno, enquanto o símbolo institucional é aquele elemento material ou moral que se incorpora no Estado, ou a entidades ou organismos dele dependentes, como meios de expressão de diversas qualidades (identidade, origem, cultura, missões, etc.), ou aquele elemento que identifica uma instituição e a diferencia das demais.

(4) Toda pessoa, cujos direitos forem violados pelo poder público, poderá recorrer à via judicial. Se não se justificar outra jurisdição, a via judicial será a dos tribunais ordinários. Mantém-se inalterado o artigo $10 \$ 2$, segunda frase.

${ }^{115}$ Cfr., supra, nota de rodapé 112.

${ }^{116}$ Cfr., no original, acórdão do Tribunal Constitucional alemão (BvR 471/10 e BvR 1181/10)... cit., §116 parte final: “[...] Die bloß visuelle Wahrnehmbarkeit ist in der Schule als Folge individueller Grundrechtsausübung ebenso hinzunehmen, wie auch sonst grundsätzlich kein verfassungsrechtlicher Anspruch darauf besteht, von der Wahrnehmung anderer religiöser oder weltanschaulicher Bekenntnisse verschont zu bleiben". Tradução pessoal: “[...] Sendo apenas visualmente perceptível, como consequência do exercício individual dos direitos fundamentais, o uso do véu islâmico deve ser aceite nas escolas, uma vez que não existe o direito constitucional de ser poupado a ser exposto a outras convicções religiosas ou ideológicas”.

${ }_{117}$ Cfr. PALOMINO, Rafael - La religión en el espacio público. Madri. Digital Reasons, 2016. ISBN 978-84944601-8-0. p. 31-32. 
Tal diferenciação é ressaltada pelo TC, no §112 do Acórdão em foco, quando se lê: “[...] se os membros individuais da equipa educativa usam o lenço de cabeça, isso não implica a identificação do Estado com uma fé particular - o que é bem diferente do caso de uma cruz ou crucifixo na sala de aula, instalado pelas autoridades estaduais (cf. BVerfGE 93, 1 <15 et seq.>). A tolerância do empregador para com a conduta religiosa da equipa educativa também não implica que a escola apresente essa conduta como exemplar, e que a paz na escola ou a neutralidade do Estado possam ser ameaçadas ou perturbadas apenas por esse motivo" ${ }^{118}$.

A neutralidade do Estado consiste em abster-se de símbolos religiosos institucionais e não em proibir os seus funcionários de usar símbolos religiosos pessoais ou adereços que possam vir a ter conotação religiosa. Por conseguinte, a liberdade religiosa positiva dos profissionais não pode ser preterida pela liberdade religiosa negativa de pais e alunos, uma vez que o Estado democrático deve proteger a diversidade.

Relativamente ao conceito de neutralidade do Estado, corroboramos a nossa ideia, já defendida no Capítulo III, no sentido de que o melhor modelo de separação entre as confissões religiosas e o Estado é a neutralidade-colaboração, entendida como "não intervenção com colaboração", ou laicidade pura e verdadeira.

Como se pode observar na decisão proferida pelo TC alemão, em 2015, foi respeitado o modelo de relações Igreja-Estado pelo qual a Alemanha ficou conhecida, qual seja, a não intervenção com colaboração (na nossa conceção, neutralidade-colaboração). O tribunal defendeu a ideia de que, ao Estado cabe não apenas, abster-se de prejudicar o exercício da liberdade religiosa pelos seus cidadãos, como também é sua responsabilidade apoiar esse exercício e colaborar com as confissões, objetivando proteger o pluralismo (pluralidade potencial).

Seguindo com a sua análise do caso, o TC da Alemanha, no §116 do Acórdão em foco, fez particular menção à necessidade de interpretar a lei em conformidade com a Constituição, para evitar uma restrição desproporcionada do direito fundamental das demandantes, com base apenas num risco abstrato de violação de outros direitos e princípios.

\footnotetext{
${ }^{118}$ Cfr., no original, acórdão do Tribunal Constitucional alemão (BvR 471/10 e BvR 1181/10)... cit., §112: “[...] Denn mit dem Tragen eines Kopftuchs durch einzelne Pädagoginnen ist - anders als dies beim staatlich verantworteten Kreuz oder Kruzifix im Schulzimmer der Fall ist (vgl. BVerfGE 93, 1 <15 ff. >) - keine Identifizierung des Staates mit einem bestimmten Glauben verbunden. Auch eine Wertung in dem Sinne, dass das glaubensgeleitete Verhalten der Pädagoginnen schulseits als vorbildhaft angesehen und schon deshalb der Schulfrieden oder die staatliche Neutralität gefährdet oder gestört werden könnte, ist einer entsprechenden Duldung durch den Dienstherrn nicht beizulegen”.
} 
Considerou o tribunal: "Por causa do peso da liberdade de crença e da liberdade da professora em professar uma confissão nas escolas interdenominacionais, uma interpretação restritiva do §57, secção 4, sentença 1, da Lei Educacional do Estado da Renânia do NorteVestfália, em conformidade com a Lei Fundamental é necessária, pelo menos para os casos em questão, na medida em que proíbe expressões de crença religiosa por aparência exterior ou conduta".

E o TC prossegue: "Para este propósito, o entendimento da capacidade de pôr em perigo ou de prejudicar a paz na escola ou a neutralidade do Estado deve ser restringido, entendendose que a expressão da crença religiosa através da aparência exterior ou conduta represente apenas um perigo abstrato, mas não um perigo suficientemente concreto para os interesses indicados no §57, secção 4, sentença 1, da Lei Educacional do Estado da Renânia do NorteVestfália. A existência desse perigo concreto deve ser comprovada e fundamentada. Em geral, utilizar um véu islâmico não justifica suficientemente um perigo concreto. Usar a cabeça coberta, como com um véu islâmico, não tem o efeito de promover uma crença, ainda menos de fazer proselitismo".

E conclui: "Mesmo que a maioria das mulheres muçulmanas não use um véu islâmico, isto não é raro na Alemanha (cf. Gabinete Federal para Migração e Refugiados <ed.>, Muslimisches Leben in Deutschland - Im Auftrag der Deutschen Islam Konferenz, 2009, pp. 194 e 195; Ministério do Trabalho, Integração e Assuntos Sociais da Renânia do NorteVestefália <ed.>, Muslimisches Leben in Nordrhein-Westfalen, 2010, p. 93). Sendo apenas visualmente perceptível, como consequência do exercício individual dos direitos fundamentais, o uso do véu islâmico deve ser aceite nas escolas, uma vez que não existe o direito constitucional de ser poupado a ser exposto a outras convicções religiosas ou ideológicas"119.

\footnotetext{
${ }^{119}$ Cfr., no original, acórdão do Tribunal Constitucional alemão (BvR 471/10 e BvR 1181/10)... cit., §116: “Das Gewicht der Glaubens- und Bekenntnisfreiheit des pädagogischen Personals in der bekenntnisoffenen Gemeinschaftsschule erfordert demnach jedenfalls für die hier gegebenen Fallkonstellationen eine reduzierende verfassungskonforme Auslegung des $\$ 57$ Abs. 4 Satz 1 SchulG NW, soweit er äußere religiöse Bekundungen untersagt. Hierfür ist das Merkmal der Eignung, den Schulfrieden oder die staatliche Neutralität zu gefährden oder zu stören, dahin einzuschränken, dass von der äußeren religiösen Bekundung nicht nur eine abstrakte, sondern eine hinreichend konkrete Gefahr für die in \$ 57 Abs. 4 Satz 1 SchulG NW genannten Schutzgüter ausgehen muss. Das Vorliegen der konkreten Gefahr ist zu belegen und zu begründen. Das Tragen eines islamischen Kopftuchs begründet eine hinreichend konkrete Gefahr im Regelfall nicht. Vom Tragen dieser Kopfbedeckung geht für sich genommen noch kein werbender oder gar missionierender Effekt aus. Ein islamisches Kopftuch ist in Deutschland nicht unüblich, auch wenn es von der Mehrheit muslimischer Frauen nicht getragen wird (vgl. Bundesamt für Migration und Flüchtlinge <Hrsg.>, Muslimisches Leben in Deutschland - im Auftrag der Deutschen Islam Konferenz, 2009, S. 194 f.; Ministerium für Arbeit, Integration und Soziales des Landes Nordrhein- Westfalen <Hrsg.>, Muslimisches Leben in Nordrhein-Westfalen, 2010, S. 93). Es spiegelt sich im gesellschaftlichen Alltag und der Schülerschaft vielfach wieder. Die bloß visuelle Wahrnehmbarkeit ist in der Schule als Folge individueller Grundrechtsausübung ebenso hinzunehmen, wie auch
} 
Quanto à questão do risco, cumpre-nos mencionar o conceito elaborado por Ulrich Beck (1997), pelo qual o sociólogo afirma que os riscos "são formas sistemáticas de lidar com os perigos e as inseguranças induzidas e introduzidas pelo próprio processo de modernização. Estes [riscos] são caracterizados pela ausência de fronteira territorial ou temporal, isto é, os mesmos são distribuídos para outras regiões, independentemente do local onde foram produzidos" $" 120$.

A questão do risco abstrato, alegada pela autoridade da Administração Escolar, para justificar a punição imposta às demandantes, mostra-se totalmente fora de propósito dentro de um Estado democrático, pois privar a liberdade de alguém, que é um direito fundamental, baseando-se meramente numa expectativa de perigo, de prejuízo, não condiz com a manifesta adesão aos princípios norteadores da liberdade e dignidade humanas, nos quais a Alemanha, enquanto Estado democrático, se funda, conforme preceitua a sua Constituição. Apenas a iminência de um risco de dano concreto justificaria a restrição do exercício de um direito fundamental.

Ainda no §116, o tribunal destacou que a Constituição não garante a ninguém o direito de ser poupado de visualizar a expressão das convicções religiosas de terceiros. Portanto, a Lei Fundamental dá a todos, igualmente, o direito de crer e manifestar a sua crença, não impedindo que uns se deparem com as crenças dos outros. Neste campo, podemos dizer que atuam os já mencionados limites imanentes aos direitos fundamentais, na medida em que a democracia e a igualdade regem a sociedade alemã. Desta forma, é imperativo esclarecer que a simples visão da manifestação de um credo diferente não constitui um perigo concreto para quem o visualiza.

Assim, o Tribunal Constitucional alemão, fazendo valer a Lei Fundamental, garante de uma sociedade democrática e igualitária, deu ganho de causa às demandantes e acentuou que a neutralidade do Estado se baseia na liberdade e não na proibição, bem como que a função educativa que o Estado partilha com os pais, abrange mostrar as diferentes culturas existentes e preparar os alunos para a diversidade atual.

$\mathrm{O}$ respeito pela diversidade significa, principalmente, reconhecer o diferente como igual, ainda que este seja parte de uma minoria, uma vez que, como refere Jorge Reis Novais (2003, p. 481), "se a determinação dos pressupostos considerados indispensáveis à convivência em comunidade é influenciada pelas conceções éticas, sociais e culturais dominantes, ela tem

sonst grundsätzlich kein verfassungsrechtlicher Anspruch darauf besteht, von der Wahrnehmung anderer religiöser oder weltanschaulicher Bekenntnisse verschont zu bleiben".

${ }^{120}$ Apud COLOMBO, Silvana; FREITAS, Vladimir Passos de - Da Teoria do Risco Concreto à Teoria do Risco Abstrato ...cit., p. 1899. 
simultaneamente de integrar e garantir as liberdades das minorias, tolerar e reconhecer como igualmente dignas de proteção as visões do mundo, convicções ou formas de vida de quem é ou pensa diferentemente e preservar a possibilidade de elas acederem a uma aceitação ou reconhecimento maioritários" $" 121$.

${ }^{121}$ Cfr. NOVAIS, Jorge Reis - As restrições aos direitos fundamentais... cit., p. 481. 


\section{Conclusões}

1.

Este trabalho visou analisar a decisão proferida pelo Tribunal Constitucional alemão em 27 de janeiro de 2015, a respeito da proteção do direito fundamental à liberdade religiosa, em particular, o direito ao uso de símbolos religiosos pelos professores das escolas públicas, expressão da sua liberdade de manifestação de crenças, quando restringido com base num risco abstrato para a neutralidade do Estado e para a liberdade religiosa de terceiros.

A sentença em foco versou sobre a confissão muçulmana, que, nos dias atuais, está a sofrer uma forte pressão e rejeição social, devido à ocorrência de atos criminosos, que nada espelham a sua real natureza, mas vêm sendo alegadamente praticados no seu nome.

Figura quase diária nas principais notícias dos jornais de todo o mundo, o Islão enfrenta uma fase difícil da sua existência, na Europa. Os fiéis, muitas vezes provenientes de Países extremamente pobres e conturbados, buscam abrigo e proteção em terras estrangeiras, onde o islamismo surge como personagem estranha à cultura e costumes locais.

Uma vez imigrados, os adeptos do islamismo criam raízes e constituem a sua vida nos Países que os acolheram e, consequentemente, a cultura islâmica e a religião muçulmana passam a fazer parte do quotidiano local. É exatamente isto que a Alemanha está a vivenciar cada vez mais intensamente.

Na condição de País economicamente forte e legalmente recetivo à imigração, a Alemanha é um dos Estados da União Europeia que mais recebe imigrantes (legais e refugiados), dos quais a maioria é adepta da religião muçulmana e faz questão de manter as suas tradições e os seus deveres religiosos no novo lar.

\section{2.}

Não se pode ignorar, nestas Conclusões, que o Islão suscita dificuldades não apenas no Ocidente. Também no Oriente, o islamismo, se relaciona com a falta de liberdade para o cristianismo e outras confissões, desta vez derivada de ações, muitas vezes violentas, com origem nos governos fundamentalistas islâmicos ou na intolerância social arraigada, invocandose os preceitos da religião muçulmana, para esse fim.

A intolerância religiosa sofrida pelo Islão, no Ocidente, filha do "laicismo", encontra assim, no Oriente, a sua correspondente em termos de privação de liberdade e subjugação, no seio do fundamentalismo. 
Nos Países europeus, a liberdade religiosa é (ou deveria ser) uma regra, porém, é uma exceção nos Países islâmicos. Aqui, fazer uso do argumento de que, no Ocidente, os muçulmanos deveriam "pagar" pela intolerância exercida contra as outras crenças nos Países islâmicos, não condiz com os princípios nos quais os Países europeus se fundam. Na Europa, a liberdade não deve ser minorada nem relativizada porque os Países islâmicos não a exercem.

Como sustenta Paulo Adragão (2014, p. 137-138) ${ }^{122}$, a prática da indução à reciprocidade, positivamente entendida, através da garantia de igual liberdade religiosa aos muçulmanos, é uma obrigação dos Estados europeus, a benefício da superação de hábitos sociais arraigados de intolerância religiosa, nos outros Países do mundo.

\section{3.}

O véu islâmico (no caso em foco, o modelo conhecido como hijab), peça que faz parte do código de vestuário feminino no Islão, foi a figura central da lide entre as profissionais da educação referidas e o Estado da Renânia do Norte-Vestfália.

Como esclarecemos no Capítulo I deste trabalho, o véu islâmico não é um "símbolo religioso", no sentido em que o Islão não adota "símbolos", mas nem por isso tal indumentária se torna menos importante para a confissão muçulmana e para os seus fiéis. Esta prática, no entanto, é uma recomendação feita pelo Alcorão (33:59) a toda mulher muçulmana, fazendo com que muitas delas queiram utilizá-lo, no sentido de cumprir, na íntegra, os seus preceitos. Pode considerar-se assim um código religioso de vestuário.

Independentemente de ser ou não um símbolo religioso, o véu tornou-se uma expressão visível do Islão e, nesse sentido, muitos Estados procuram impedir a sua utilização em espaços e locais públicos, incluíndo-se aqui as escolas estatais, sob o argumento de que a visão de uma expressão religiosa diferente significaria uma ofensa à liberdade religiosa negativa de terceiros ou, ainda, que poria em causa a neutralidade do Estado em questão.

As Constituições democráticas preveem e protegem o direito fundamental à liberdade religiosa, não fazendo diferenciação entre liberdade religiosa positiva e liberdade religiosa negativa, bem como não privilegiando qualquer crença em detrimento de outra. Desta forma, não se pode "ponderar"123 entre aspetos essencialmente equivalentes do mesmo direito

\footnotetext{
${ }^{122}$ Cfr. ADRAGÃO, Paulo Pulido - O caso Asia Bibi, Paquistão (2009 - ...), visto da Europa, in ADRAGÃO, Paulo Pulido (coord.) - Atas do I Colóquio Luso-Italiano sobre Liberdade Religiosa. Coimbra. Almedina, 2014. ISBN 9789724054247. p. 137-138.

${ }^{123}$ Cfr. diferença entre "ponderação" e "proporcionalidade" no Capítulo IV, alínea c).
} 
fundamental, entre dois direitos concêntricos, como a liberdade religiosa positiva e a liberdade religiosa negativa.

A manifestação de uma fé não pode ser considerada ofensiva para com aqueles que dela não compartilham, assim como o facto de uma professora de escola pública usar um objeto pessoal de cunho religioso, como o hijab, não torna o Estado um seguidor daquela prática específica ou de qualquer outra.

Outro argumento abraçado por aqueles que advogam contra a utilização do véu islâmico é a defesa da liberdade das mulheres. Essa perspectiva defende que o véu é uma forma de subjugar as mulheres, inferiorizando-as perante os homens. Todavia, como vimos, para o Islão, o véu nada tem a ver com inferiorizar ou subjugar o sexo feminino, tratando-se apenas de uma vestimenta com o intuito de proteger a mulher, identificando-a como uma fiel muçulmana. Muitas mulheres muçulmanas usam livremente o véu, uma vez que têm a opção entre cumprir ou não este dever religioso, que não é uma imposição, pelo menos para as crentes muçulmanas residentes em Países ocidentais.

Por outro lado, torna-se claro que existe uma contradição considerável em querer defender a liberdade de alguém, proibindo-o de fazer algo. Simplesmente, não faz sentido libertar uma pessoa através da proibição de exercer um direito fundamental, como seja praticar a sua crença livremente.

\section{4.}

A Constituição alemã, no art. $4^{\circ}$, reconhece a liberdade religiosa e o seu livre exercício, enquanto direito fundamental inviolável, e reforça a proteção dessa liberdade ao prever no seu art. $33^{\circ}$ que nenhum cidadão será privado do gozo dos seus direitos cívicos, da admissão em cargos públicos e de direitos adquiridos no serviço público, bem como ninguém poderá sofrer discriminação em razão da religião que professar.

Ao interpretar o texto da Constituição, o tribunal observou a proporcionalidade, a fim de produzir a devida coordenação entre os direitos, e aplicou o princípio da concordância prática, corroborando que o direito fundamental à liberdade religiosa positiva dos profissionais da educação e o direito fundamental à liberdade religiosa negativa de pais e alunos são equivalentes e de igual valor.

Assim, o Tribunal Constitucional alemão, acertadamente, entendeu, no Acórdão de 2015, que o direito à liberdade religiosa positiva dos professores e demais componentes do corpo educacional público não pode ser preterido em razão do direito à liberdade religiosa 
negativa de pais e alunos e que a neutralidade do Estado não se encontra ferida pelo facto dos docentes e demais funcionários das escolas públicas usarem símbolos religiosos ou outros objetos pessoais de cunho religioso. Com esta decisão, tornou-se claro que a Alemanha é um Estado adepto da não intervenção com colaboração (a que chamamos neutralidadecolaboração).

O §57, secção 4, sentença 3, da Lei Educacional do Estado da Renânia do NorteVestfália (norma discutida no julgado), ainda abria uma exceção em favor da exibição dos símbolos cristãos, contrariando o preceito do art. $19^{\circ}$, da Constituição alemã, que preconiza a necessidade de a lei restritiva de direitos fundamentais ser genérica, não se limitando a determinada crença, norma considerada inconstitucional.

Ponto complementar e de grande valor da decisão proferida pelo TC alemão, ao rever a interpretação e constitucionalidade do §57, secção 4, da Lei Educacional do Estado da Renânia do Norte-Vestfália, foi a vinculação das decisões futuras dos tribunais ordinários, ordenando que estes sigam uma interpretação da lei conforme a Constituição, protegendo, assim, a liberdade religiosa e o seu exercício.

\section{5.}

Neste contexto, se percebe que tentar fazer das escolas públicas locais completamente isentos de qualquer visão ou menção às religiões é uma atitude contrária ao real papel da escola e do Estado educador, numa sociedade democrática e plural.

No seio de uma comunidade constituída por diversos grupos sociais e culturais, onde vigora a democracia e os direitos fundamentais são reconhecidos pela Constituição, é dever do Estado reconhecer a diversidade e educar os cidadãos quanto à necessidade de conviver e respeitar o diferente, ensinando-os que "ser diferente" não significa "ser errado".

Como lembra Paulo Adragão (2014, p. 137) ${ }^{124}$, “a intolerância religiosa social é, provavelmente, o maior obstáculo à liberdade religiosa: ela sustenta e perpetua a intolerância religiosa legal". Assim, o caminho para uma sociedade pacífica, na atual pluralidade que vivemos, está, sobretudo, na educação, no conhecimento, uma vez que o ser humano tende a temer o desconhecido e, consequentemente, a eliminá-lo.

\footnotetext{
${ }^{124}$ Cfr. ADRAGÃO, Paulo Pulido - O caso Asia Bibi, Paquistão (2009 - ...), visto da Europa, in ADRAGÃO, Paulo Pulido (coord.) - Atas do I Colóquio... cit., p. 137.
} 
6.

Acertadamente, em 2015, o TC alemão ressaltou a impossibilidade de um mero risco abstrato para outros direitos e princípios ser suficiente para justificar a restrição do exercício de um direito fundamental.

A Constituição protege igualmente o direito de todos os cidadãos praticarem e vivenciarem a sua fé livremente, o que inclui usar símbolos e objetos de cunho religioso em público.

A simples visão de uma manifestação de fé alheia não é, em si mesma, um risco concreto à liberdade religiosa negativa daqueles que professam uma fé diferente ou não professam fé alguma, da mesma forma que o exercício individual da liberdade religiosa de um profissional público não consiste numa quebra da neutralidade do Estado que o emprega.

O princípio da interpretação das leis conforme a Constituição, adotado pelo Tribunal, corroborou a excelência e a primazia do direito fundamental em análise. Ao reinterpretar as sentenças 1 e 2, e anular a sentença 3, todas da secção 4, do §57, da Lei Educacional da Renânia do Norte-Vestfália, a decisão declarou a todos que a liberdade religiosa dos professores não pode ser preterida e que nenhuma confissão pode ser sobreposta a outra.

\section{7.}

Cumpre à comunidade política, aos Governos, aos legisladores, aos aplicadores do Direito, saber criar mecanismos eficientes para separar o certo do errado, o bem do mal, o justo do injusto.

A liberdade religiosa é um direito fundamental, previsto em todas as Constituições democráticas, bem como em várias cartas de direitos, assinadas por Nações comprometidas com a liberdade e a justiça. Tal direito fundamental diz respeito, igualmente, a todas as confissões religiosas e a todas as pessoas.

Um direito fundamental não deve ser objeto de restrições baseadas em meros riscos abstratos ou em meras expectativas de perigo e não em perigos concretos ou atuais para outros direitos e princípios.

\section{8.}

Saúda-se aqui o Tribunal Constitucional alemão, pois, apesar de ter errado na decisão proferida em 2003, o citado caso Ludin, induzindo o Estado de Bade-Vurtemberga, e vários outros, a criar legislação proibitiva do uso de símbolos religiosos pelos professores das escolas 
públicas, ele se mostrou, em 2015, digno e comprometido com a liberdade religiosa dos mesmos professores e a defesa dos direitos fundamentais constitucionalmente previstos, corrigindo o seu erro ao proferir uma decisão diferente, puramente baseada no respeito pela Constituição e pelo direito fundamental em análise.

Saudamos também o Tribunal Constitucional português que, no seu acórdão 174/93, reconheceu que cooperar com as confissões religiosas, através do ensino, não fere a neutralidade do Estado, mostrando, assim, que Portugal é, neste ponto, um Estado de Direito democrático.

Infelizmente, os tribunais de outros Países da Europa e o próprio Tribunal Europeu dos Direitos do Homem, ao contrário dos tribunais constitucionais alemão e português, não têm privilegiado, nem protegido a liberdade religiosa nos mesmos termos, como se pode observar no referido caso Dahlab v. Suíça (2001).

\section{9.}

Dentro da ideia de separação entre Estado e Igreja, adotada pelos Estados democráticos que se nomeiam "laicos", o conceito de neutralidade nem sempre é corretamente entendido por todos eles.

Podemos concluir que, apesar dos Países aqui estudados, a Alemanha, Portugal e a Suíça, se dizerem neutros (laicos) apenas a Alemanha e Portugal adotam um entendimento correto do termo, pondo efetivamente em prática a "neutralidade-colaboração", expressão da laicidade pura e verdadeira.

A Suíça, pelo contrário, corroborada pelo TEDH, não obstante também se dizer um Estado laico, pratica a "neutralidade-negação" (ou laicismo), reprimindo a expressão das crenças e eliminando a visão da diversidade religiosa dos espaços públicos.

\section{0.}

Vivemos num mundo cada vez mais plural, onde a globalização faz com que culturas totalmente diferentes passem a viver lado a lado e crianças com proveniências diversas compartilhem as mesmas salas de aula.

Para se alcançar a paz e o desenvolvimento social, o ideal é que os Países adotem e pratiquem a não intervenção com colaboração ou laicidade pura e verdadeira, por nós entendida como "neutralidade-colaboração". A prática da "neutralidade-colaboração" requer que os Estados se fundem na promoção da alteridade em matéria de liberdade religiosa. 
Cada cidadão, verdadeiro detentor do poder nos Estados democráticos de direito, precisa de despertar o seu lado mais humano e colocar-se no lugar do próximo. A partir do momento em que somos capazes de sentir a dor e a alegria do outro, somos inevitavelmente capazes de entender e aceitar o diferente, sendo isso possível apenas através do conhecimento, da educação, do esclarecimento.

É imprescindível, para o equilíbrio social, a prática da "ética da alteridade" (Álvaro Cruz $)^{125}$.

11.

Após a investigação empreendida, mostra-se claro que não basta aos Estados dizeremse laicos nem escreverem na Constituição que a liberdade religiosa é protegida. É fundamental que eles adotem o respeito pela prática da liberdade religiosa efetiva.

Além disso, não se pode descansar no "conforto" de um texto constitucional, pois, como se viu no caso da proibição dos minaretes na Suíça, uma Constituição pode ser alterada, no sentido de restringir a liberdade religiosa, quando assim interessar ao Estado.

Por isso, apesar de realçarmos a Alemanha pela sábia decisão do seu Tribunal Constitucional em 2015, não podemos abster-nos de manifestar a nossa preocupação perante situações como a ocorrida recentemente na Baviera, onde o Tribunal Administrativo proibiu as suas funcionárias de usarem o véu islâmico no interior das instalações ${ }^{126}$.

A Alemanha, assim como outros Países que seguem a prática da neutralidadecolaboração, têm por diante o desafio de não se desviarem do "caminho correto", qual seja, o da efetiva proteção e promoção da vivência da liberdade religiosa pelos seus cidadãos.

12.

Liberdade e dignidade andam de mãos dadas e a liberdade religiosa, na qualidade de “mãe de todas as liberdades”, configura a expressão máxima da dignidade humana.

É inegável que a religião é um elemento fundamental para o desenvolvimento da sociedade porque o é para o desenvolvimento das pessoas. Como referem Bavaresco e Lima (2012), a religião é tão importante para uma sociedade “a ponto de Habermas [a] conceber como

\footnotetext{
${ }^{125}$ Cfr. CRUZ, Álvaro Ricardo de Souza [et al] - A Laicidade para além... cit.

${ }^{126}$ Cfr. Ein glaubensfreier Gerichtssaal ist eine Fiktion. Süddeutsche Zeitung de 7 de março de 2018. [em linha]. [Consultado em 3 de julho de 2018]. Disponível em http://www.sueddeutsche.de/bayern/kopftuch-urteilein-glaubensfreier-gerichtssaal-ist-eine-fiktion-1.3895758.
} 
dimensão imprescindível da aprendizagem evolutiva, ou seja, como mecanismo vital no desenvolvimento da capacidade humana de conhecimento, de linguagem e de ação"127.

Desta forma, concluímos este trabalho, esperançosos de que outros tribunais sigam a decisão tomada pelo Tribunal Constitucional alemão, no acórdão de 27 de janeiro de 2015, no sentido de preservar a liberdade religiosa, uma vez que se trata de uma liberdade fundamental. Como afirma Paulo Adragão (2002, p. 178), “entre impedir o seu exercício, para evitar riscos, e proteger o seu exercício, correndo riscos, a opção há-de ser a segunda: in dubio pro libertate 128 .

${ }^{127}$ Apud BAVARESCO, Agemir; LIMA, Francisco Jozivan Guedes de - A ideia rawlsiana de razão pública: Limites e alternativas a partir de Habermas. Sol Nascente - Revista do Centro de Investigação sobre Ética Aplicada (CISEA). No 2. Setembro de 2012. [Em linha]. [Consultado em 20 de abril de 2017]. Disponível em www.ispsn.org/sites/default/files/magazine/articles/N2\%20art6.pdf. p. 9.

${ }^{128}$ Cfr. ADRAGÃO, Paulo Pulido - A Liberdade Religiosa... cit., p. 178. 
Bibliografia consultada

\section{Doutrina}

ADAMGY, Yiossuf (coord.) - O véu islâmico, análise e esclarecimento. $1^{\mathrm{a}}$ ed. Loures. Editado por: Al Furqán, 2004. Dep. Legal no 3017/04;

ADRAGÃO, Paulo Pulido,

- A Liberdade Religiosa e o Estado. Coimbra. Almedina, 2002. ISBN 972-40-1767-2;

- Levar a sério a liberdade religiosa - uma reformulação crítica dos estudos sobre Direito das Relações Igreja-Estado. Coimbra. Almedina, 2012. ISBN 978-972-40-45740

- O caso Asia Bibi, Paquistão (2009 - ...), visto da Europa, in ADRAGÃO, Paulo Pulido (coord.) - Atas do I Colóquio Luso-Italiano sobre Liberdade Religiosa. Coimbra. Almedina, 2014. ISBN 9789724054247. p. 131-138;

BAVARESCO, Agemir; LIMA, Francisco Jozivan Guedes de - A ideia rawlsiana de razão pública: Limites e alternativas a partir de Habermas. Sol Nascente - Revista do Centro de Investigação sobre Ética Aplicada (CISEA). No 2. Setembro de 2012. [Em linha]. [Consultado em 20 de abril de 2017]. Disponível em www.ispsn.org/sites/default/files/magazine/articles/N2\%20art6.pdf;

BETTETINI, Andrea - Relazionalità della persona, rilevanza pubblica del fatto religioso e tolleranza, in ADRAGÃO, Paulo Pulido (coord.) - Atas do I Colóquio Luso-Italiano sobre Liberdade Religiosa. Coimbra. Almedina, 2014. ISBN 9789724054247. p. 31-36;

BULOS, Uadi Lammêngo - Curso de direito constitucional. $4^{\mathrm{a}}$ ed. São Paulo. Saraiva, 2009. ISBN 9788502075849;

CAMPOS, Manuel Fontaine - Da intolerância com as crenças minoritárias à intolerância com as crenças maioritárias: a propósito dos acórdãos do TEDH no caso Lautsi, in ADRAGÃO, Paulo Pulido (coord.) - Atas do I Colóquio Luso-Italiano sobre Liberdade Religiosa. Coimbra. Almedina, 2014. ISBN 9789724054247. p. 222-233;

CANOTILHO, J. J. Gomes; MOREIRA, Vital - Constituição da República Portuguesa Anotada. Volume I. $4^{\mathrm{a}}$ edição revista. Coimbra. Editora Coimbra, 2007. ISBN 978-97232-1462-8;

COETZEE, P.H.; ROUX, A.P.J. - Ludin's Kopftuch/(headdress): A problem of religious freedom in German schools. Koers: Bulletin for Christian Scholarship (2004). [em 
linha]. [Consultado em 02 de maio 2017]. Disponível em

http://www.koersjournal.org.za/index.php/koers;

COLOMBO, Silvana; FREITAS, Vladimir Passos de - Da Teoria do Risco Concreto à Teoria

do Risco Abstrato na Sociedade Pós-industrial: um estudo da sua aplicação no âmbito do Direito Ambiental. Quaestio Iuris. Vol. 08, nº 03 (2015). Rio de Janeiro. p. 1895-1912; COUTINHO, Luís P. Pereira - O facto do pluralismo e a fiscalização judicial da constitucionalidade, in ADRAGÃO, Paulo Pulido (coord.) - Atas do I Colóquio LusoItaliano sobre Liberdade Religiosa. Coimbra. Almedina, 2014. ISBN 9789724054247. p. 69-78;

CRUZ, Álvaro Ricardo de Souza; DUARTE, Bernardo Augusto Ferreira; TEIXEIRA, Alessandra Sampaio - A Laicidade para além de Liberais e Comunitaristas. Vol. 08. Coleção Professor Álvaro Ricardo de Souza Cruz. Belo Horizonte. Arraes Editores, 2017. ISBN 978-85-8238-276-9;

CRUZ, Manuel Braga da - Europeísmo, Nacionalismo, Regionalismo, in Análise Social. Vol. XXVII. Instituto Ciências Sociais da Universidade de Lisboa, 1992;

EVANS, Malcolm D.,

- From cartoons to crucifixes: current controversies concerning the freedom of religion and the freedom of expression before the European Court of Human Rights, in Journal of Law and Religion. Vol. 26, $\mathrm{n}^{\mathrm{o}} 1$ (2010), p. 345-370;

- Manual on the Wearing of Religious Symbols in Public Areas. V.21, $\mathrm{n}^{\circ} 2$ (2010). Security and Human Rights;

FOLQUE, André - A qualificação jurídica dos fins religiosos: questões e desafios, in ADRAGÃO, Paulo Pulido (coord.) - Atas do I Colóquio Luso-Italiano sobre Liberdade Religiosa. Coimbra. Almedina, 2014. ISBN 9789724054247. p. 157-175;

HÄBERLE, Peter - Estado Constitucional Cooperativo. Tradução: Marcos Augusto Maliska e Elisete Antoniuk. Rio de Janeiro. Renovar, 2007. ISBN 978857147-624-0;

HABERMAS, Jürgen,

- Religion in the Public Sphere. European Journal of Philosophy. V. 14. (Abril/2006);

- Um ensaio sobre a Constituição da Europa. Tradução: Marian Toldy e Teresa Toldy. Lisboa. Edições 70, 2012. ISBN 978-972-44-1700-4;

HABERMAS, Jürgen; RATZINGER, Joseph - Dialética da Secularização: Sobre razão e religião. Tradução: Alfred J. Keller. Aparecida. Editora Ideias \& Letras, 2007. ISBN 97885-98239-82-8; 
HEINIG, Hans Michael - Der Körperschaftsstatus nach Art. 137 Abs. 5 S. 2 WRV, in REUTER, Astrid; KIPPENBERG, Hans G. (Coords.) - Religionskonflikte im Verfassungsstaat. Göttingen. Vandenhoeck \& Ruprecht, 2010. ISBN 978-3-525-54008-4; HESSE, Konrad - Elementos de Direito Constitucional da República Federal da Alemanha (Grundzüge des Verfassungsrechts der Bundesrepublik Deutschland). Tradução: Luís Afonso Heck. Porto Alegre. Sergio Antonio Fabris Editor, 1998. ISBN 85-88278-05-7;

IHERING, Ruddolf von - A Luta pelo Direito. Versão para EBook - $2^{\text {a }}$ ediç̧ão. eBooksBrasil.com, 2016. Disponível em http://www.ebooksbrasil.org/eLibris/luta.html. (do original: IHERING, Rudolf von - A Luta pelo Direito. Tradução: João de Vasconcelos. São Paulo. Martin Claret, 2009. ISBN 9788572327817);

JERÓNIMO, Patrícia,

- Símbolos e símbolos - o véu islâmico e o crucifixo na jurisprudência recente do Tribunal Europeu dos Direitos do Homem: Análise das decisões Sahin v. Turquia, Dogru v. França e Lautsi v. Itália, in Scientia Juridica, Tomo LIX, n. 323 (2010), p. 496-523;

- Intolerância religiosa e minorias islâmicas na Europa - A censura do "Islão visível" - os minaretes e o véu - e a jurisprudência conivente do TEDH, in ADRAGÃO, Paulo Pulido (coord.) - Atas do I Colóquio Luso-Italiano sobre Liberdade Religiosa. Coimbra. Almedina, 2014. ISBN 9789724054247. p. 85-130;

MACHADO, Jónatas,

- Tomemos a sério a separação das igrejas do Estado (Comentário ao Acórdão do Tribunal Constitucional No 174/1993). Revista do Ministério Público nº58 (Ano 15), Abril/Junho de 1994. p. 45;

- Liberdade religiosa numa comunidade constitucional inclusiva: dos direitos da verdade aos direitos dos cidadãos. Boletim da Faculdade de Direito da Universidade de Coimbra. Coimbra. Coimbra Editora, 1996. Studia iuridica 18. ISBN 972-32-0729-X;

- A Jurisprudência Constitucional Portuguesa diante das Ameaças à Liberdade Religiosa. Boletim da Faculdade de Direito de Coimbra, LXXXII (2006). p. 65;

MAZZOLA, Roberto - Le contraddizioni dello Stato costituzionale di fronte ai fenomeni di intolleranza religiosa in Europa, in ADRAGÃO, Paulo Pulido (coord.) - Atas do I Colóquio Luso-Italiano sobre Liberdade Religiosa. Coimbra. Almedina, 2014. ISBN 9789724054247. p. 138-153; 
MEYERSON, D. - Rights Limited: Freedom of Expression, Religion and the South African Constitution. Cape Town. Juta, 1997. ISBN 9780702143960;

MIRANDA, Jorge - Estado, Liberdade Religiosa e Laicidade. Gaudium Sciendi, №4 (Julho/2013), Universidade Católica - Sociedade Científica;

MIRANDA, Jorge; MEDEIROS, Rui - Constituição Portuguesa Anotada. Tomo I. $2^{\mathrm{a}}$ edição, revista, actualizada e ampliada. Coimbra. Coimbra Editora, 2010. ISBN 978-972-32-18220

NOVAIS, Jorge Reis - As restrições aos direitos fundamentais não expressamente autorizadas pela Constituição. Coimbra. Coimbra Editora, 2003. ISBN 972-32-1177-7;

ORTIZ, Javier Ferrer (coord.); FORNÉS, Juan; DEL VALLE, José María G.; LOMBARDÍA, Pedro; ALARCÓN, Mariano L.; NAVARRO-VALLS, Rafael; VILADRICH, Pedro-Juan - Derecho Eclesiástico del Estado Español. 6a ed. Pamplona. EUNSA, 2007. ISBN 97884-313-2496-4;

PALOMINO, Rafael,

- Legal dimensions of secularism: challenges and problems. Madrid, 2011. Universidade Complutense;

- La religión en el espacio público: Los símbolos religiosos ante el derecho. Madrid. Digital Reasons, 2016. ISBN 978-84-944601-8-0;

SEABRA, João - Liberdade religiosa, Estado laico e religião no espaço público: desenvolvimentos recentes na Europa, in ADRAGÃO, Paulo Pulido (coord.) - Atas do I Colóquio Luso-Italiano sobre Liberdade Religiosa. Coimbra. Almedina, 2014. ISBN 9789724054247. p. 55-66;

SETIÉN ALBERRO, José Maria; POLICARPO, José (co-autor) - Laicidade e Laicismo Igreja, Estado e Sociedade (Laicidad del Estado y Iglesia). Tradução: Margarida Osório Gonçalves. Coimbra. Gráfica de Coimbra 2, 2008. ISBN 978-972-603-424-7;

SINNER, Rudolf von - Dossiê: Religião e globalização - Estado e religiões - O exemplo da Alemanha. Civitas. V.14, no 3 (Set-Dez, 2014). Porto Alegre;

TODOROV, Tzvetan - Os inimigos íntimos da democracia (Les ennemis intimes de la démocratie). Tradução: Joana Angélica d'Avila Melo. São Paulo. Companhia das Letras, 2012. ISBN 978-85-359-2142-7. 


\section{Jurisprudência}

\section{Tribunal Constitucional alemão}

- BvR 1436/02, de 24 de setembro de 2003;

- BvR 471/10 e BvR 1181/10, de 27 de janeiro de 2015.

\section{Tribunal Constitucional português}

- Acórdão 174/93, de 17 de fevereiro de 1993.

\section{Tribunal Europeu dos Direitos do Homem}

- Acórdão Kokkinakis v. Grécia, de 25 de maio de 1993;

- Acórdão Dahlab v. Suíça, de 15 de fevereiro de 2001;

- Acórdão Sahin v. Turquia, de 10 de novembro de 2005;

- Acórdão Dogru v. França, de 04 de dezembro de 2008;

- Acórdão Lautsi v. Itália, de 03 de novembro de 2009 (2a secção);

- Acórdão Lautsi v. Itália, de 18 de março de 2011 (Pleno);

- Decisão do TEDH sobre o recurso Ouardiri v. Suíça, de 28 de junho de 2011 (2ª secção).

\section{Documentos}

- Bundesministerium des Innern, für Bau und Heimat. [em linha]. [Consultado em 22 de abril de 2018]. Disponível em http://www.bmi.bund.de/;

- Comunidade Islâmica de Lisboa. [em linha]. [Consultado em 06 de agosto de 2018]. Disponível em http://comunidadeislamica.pt/;

- Constituição da República Portuguesa de 1976. Assembleia da República. [em linha]. [Consultada em 28 de março de 2018]. Disponível em http://www.parlamento.pt/Legislacao/Paginas/ConstituicaoRepublicaPortuguesa.aspx;

- Convenção Europeia dos Direitos do Homem. European Court of Human Rights. [em linha]. [Consultado em 26 de abril de 2018]. Disponível em https://www.echr.coe.int/Documents/Convention_POR.pdf;

- Declaração Universal dos Direitos do Homem. Diário da República Eletrónico. [em linha]. [Consultado em 8 de agosto de 2018]. Disponível em https://dre.pt/declaracaouniversal-dos-direitos-humanos; 
- Destatis - Statistisches Bundesamt. [em linha]. [Consultado em 23 de abril de 2018]. Disponível em https://www.destatis.de/DE/Startseite.html;

- Dicionário da Língua Portuguesa Contemporânea da Academia das Ciências de Lisboa. Volumes I-II. Academia das Ciências de Lisboa e Editorial Verbo, 2001. Dep. Legal $n^{\circ} 161290 / 01$;

- Ein glaubensfreier Gerichtssaal ist eine Fiktion - Süddeutsche Zeitung de 7 de março de 2018. [em linha]. [Consultado em 3 de julho de 2018]. Disponível em http://www.sueddeutsche.de/bayern/kopftuch-urteil-ein-glaubensfreier-gerichtssaalist-eine-fiktion-1.3895758;

- Islam em Linha. [em linha]. [Consultado em 06 de agosto de 2018]. Disponível em http://islamemlinha.com/;

- Lei Fundamental da Alemanha. Deutscher Bundestag. [em linha]. [Consultado em 26 de abril de 2018]. Disponível em https://www.btg-bestellservice.de/pdf/80208000.pdf;

- LORENA, Sofia - Decisão da justiça sobre véu vai "banir muçulmanas do mercado de trabalho". Jornal Público. 14 Mar. 2017. [em linha]. [Consultado em 5 de abril de 2017]. Disponível em https://www.publico.pt/2017/03/14/mundo/noticia/decisao-dajustica-europeia-sobre-o-veu-abre-porta-a-discriminacoes-1765207;

- Pew Research Center. [em linha]. [Consultado em 23 de abril de 2018]. Disponível em http://www.pewresearch.org/;

- Pordata - Base de Dados Portugal Contemporâneo. [em linha]. [Consultado em 23 de abril de 2018]. Disponível em https://www.pordata.pt/MicroPage.aspx ?DatabaseName=Europa\&MicroName=Popul a\%C3\%A7\%C3\%A3o+estrangeira+em+percentagem+da+popula\%C3\% A7\% $3 \% \mathrm{~A} 3$ o+residente\&MicroURL=1624\&;

- Portaria 333/86. Diário da República Eletrónico. [em linha]. [Consultado em 28 de março de 2018]. Disponível em https://dre.pt/pesquisa-avancada//asearch/228620/details/maximized?serie=I\&search=Pesquisar\&ano=1986\&perPage $=$ 100\&types $=$ DR $\&$ dreId=90568/en/en;

- Portaria 831/87. Diário da República Eletrónico. [em linha]. [Consultado em 28 de março de 2018]. Disponível em https://dre.pt/web/guest/pesquisa//search/496359/details/normal?q=portaria+831\%2F87; 
- Sarkozy diz que burca não é bem-vinda na França - BBC notícias. [em linha]. [Consultado em 14 de fevereiro de 2018]. Disponível em http://www.bbc.com/portuguese/noticias/2009/06/090622_sarkozyburca_np.

\section{Entrevistas}

- Professor Mahmoud: Nascido em Portugal, Jaime Manuel Pontes Soares, conhecido na comunidade islâmica como Mahmoud, tem formação em Filosofia e em Estudos Portugueses. Fez dois mestrados, um deles em Ensino da Filosofia no ensino secundário, pela Faculdade de Letras da Universidade do Porto, e outro em Estudos Portugueses Interdisciplinares, pela Universidade Aberta. Tem licenciatura em Filosofia também pela Faculdade de Letras da Universidade do Porto.

Ao longo dos há cerca de 15 anos em que é professor, leciona as disciplinas de Filosofia, Psicologia, Sociologia, Cidadania, Área de Integração, Desenvolvimento Pessoal e Social e, ainda, Mundo Atual, quer a alunos jovens, quer a adultos.

Nasceu no seio de uma família com formação católica, mas, com os estudos universitários, ampliou os seus conhecimentos e interesses pela Filosofia Islâmica e pelo Islão, em particular. Durante vários anos estudou, de forma mais aprofundada, a literatura islâmica e o Alcorão, tendo-se, então, convertido ao islamismo, tornando-se muçulmano.

Na comunidade islâmica do Porto, trabalha de forma ativa, em estreita colaboração com o Sr. Abdul Rehman Mangá (Presidente do Centro Cultural Islâmico do Porto), tendo participado de vários projetos, como a Biblioteca Humana, promovida pela Câmara Municipal de Valongo, que visa combater a discriminação das minorias, bem como participou de várias conferências sobre temas religiosos e de programas televisivos, que tiveram como temática central o diálogo inter-religioso e a tolerância. Para além disso, é, ainda, responsável pelas visitas de não muçulmanos à Mesquita do Heroísmo, no Porto, grupo formado, principalmente, por alunos e professores das várias escolas do País. (Fonte: o próprio entrevistado);

- Sheikh David Munir: Nascido em Moçambique, no ano de 1963, David Munir é filho de pai iemenita e mãe moçambicana de ascendência indiana. Começou os seus estudos religiosos em 1975 numa madraça, na Índia (Madrassah Ashrafia), onde memorizou o Alcorão em 1986. 
Licenciou-se em Teologia Islâmica no Instituto Aleemiyah, Centro islâmico de Carachi, Paquistão, e prosseguiu os seus estudos islâmicos na Universidade de Carachi, onde se licenciou em Pedagogia e fez o Bacharelato no Curso de Letras.

Em 1986, com 23 anos, deixou o Paquistão e é, desde essa altura, o imã da Mesquita Central de Lisboa, ministro de culto, docente de língua árabe e cultura islâmica e Conselheiro Religioso da Comunidade Islâmica de Lisboa.

Foi professor de língua árabe no Instituto Oriental da Universidade Nova de Lisboa, na Universidade Independente e na Universidade Lusófona de Humanidades e Tecnologias.

É membro do Conselho Consultivo Internacional da Fundação Paz e Democracia Monsenhor Martinho da Costa Lopes.

Tem como obras publicadas: "Deus que nunca o foi" (1987), "Ensinamentos Elementares do Islão" (1988) e "Da Ciência e Filosofia à Religião" (1996). (Fonte: O Lugar da Cultura - modelos e desafios. [em linha]. [Consultado em 7 de agosto de 2018]. Disponível em http://olugardacultura.pt/);

- Senhora Nadia Ettaouass e Senhor Islam Reis: A Sra. Nadia Ettaouass (33 anos de idade) nasceu em Marrocos, no seio de uma família muçulmana e sempre professou sua fé de nascença. Em Marrocos, exercia a profissão de tradutora, mas, ao casar-se com o Sr. Islam Reis (português), mudou-se para Portugal e trabalhou no comércio.

O Sr. Islam Reis (35 anos de idade) nasceu em em Portugal e converteu-se ao islamismo na idade adulta. Atualmente, o Sr. Islam exerce a profissão de operário fabril.

A Sra. Nadia e o Sr. Islam são casados, moram na cidade do Porto e têm um filho de 2 anos de idade. (Fonte: os próprios entrevistados). 


\title{
$\underline{\operatorname{Anexo} A}$
}

\section{Transcrição do áudio da entrevista concedida pelo Professor Mahmoud (Professor de}

\section{Filosofia e membro do Centro Cultural Islâmico do Porto)}

\author{
Local: Mesquita - Centro Cultural Islâmico do Porto
}

Data: $3 / 11 / 2017$

\section{Horário: $11 \mathrm{~h} 00$}

Pergunta: Qual a importância do uso do véu?

Professor Mahmoud: O Alcorão faz algumas referências ao uso do hijab, ou melhor, ao uso não, ao uso de nenhum vestuário em específico, mas a prescrição das mulheres deverem tapar algumas partes do corpo, ou seja, o Alcorão não refere de fato que as mulheres deverão usar determinado tipo de vestuário, o hijab ou burqa ou niqab, não diz claramente isso. Os termos que o alcorão utiliza são sempre que a mulher deve tapar os seus atrativos corporais ou seus adornos corporais. Então, nesta medida, o hijab nós não podemos considerar que ele é uma obrigação, há sempre uma dimensão de livre arbítrio no que o crente muçulmano faz, mas como uma prescrição religiosa que é feita, como forma de prevenir algumas situações das quais as mulheres são normalmente vítimas. O que acontece muito nas cidades ocidentais é que é deixada à mulher essa escolha, essa decisão de usar ou não, se bem que, obviamente, que é sempre mais importante e melhor ela usar o hijab, ou usar outro tipo de vestimenta para tapar essas partes do corpo do que não usar, essa liberdade é deixada à mulher, portanto, essa é a prescrição que é feita no Alcorão. Mas, é importante, de fato, que use.

Quando eu digo que não é obrigatório, não é obrigatório no sentido em que não há nenhuma [lei] com exceção de alguns Países, que são Países islâmicos, que são Países confessionais, em que o uso...[salto na fala], por exemplo, eu estou a falar no caso da Arábia Saudita, que prescreve claramente, sem qualquer tipo de outra escolha, que a mulher tem de usar o niqab, com exceção desses Países. Onde não há uma lei islâmica, que seja praticada nessas sociedades, é sempre deixado à mulher essa liberdade, como é sempre deixado ao crente a liberdade de pagar o...[salto na fala] ou fazer o Ramadão ${ }^{1}$, portanto, há aqui sempre uma dose, no crente

\footnotetext{
${ }^{1}$ Ramadão ou jejum de Ramadão: é um dos pilares do Islão e, “na sua definição literal, significa abstinência de comer, de beber, de ter relações íntimas e de fumar no espaço, entre o período antes da alvorada até ao pôr-dosol, durante o mês de Ramadão, que é o nono mês do calendário islâmico". Cfr. Comunidade Islâmica de Lisboa. [em linha]. [Consultado em 06 de agosto de 2018]. Disponível em http://comunidadeislamica.pt/pt/religiao-e-culto/os-pilares-do-islao/jejum-de-ramadao.
} 
islâmico, de livre arbítrio. Então, Deus prescreve, mas, depois, cada um de nós, daquilo que acha que é sua crença e o caminho que deve seguir, usa ou não usa, pratica ou não pratica. Não podemos dizer que é uma obrigatoriedade, no sentido de que há alguém que puna as pessoas que não usem. No mundo ocidental, não há essa punição, em muitos Países não há, em outros, como eu lhe digo, haverá essa punição, uma vez que é obrigatório por lei o uso de alguma vestimenta. Portanto, temos aqui essas duas alternativas relativamente ao uso do hijab, agora, no Alcorão não há de fato nenhuma punição que diz que as mulheres têm que usar, não é uma prescrição, é uma recomendação que as mulheres devem tapar tal como os homens. Digamos que há dois aspetos que são mais ou menos transversais, no caso, os homens e as mulheres, é a modéstia e a discrição no vestuário. No caso das mulheres, sobretudo porque houve sempre vários exemplos na história de sociedades em que as mulheres foram assediadas, então, por uma questão de segurança para as mulheres foi prescrito que elas pudessem tapar algumas partes de seu corpo e as partes que pudessem ser, de alguma forma, símbolo de sua sensualidade e causar, assim, situações de assédio, portanto, foi prescrito que elas, recomendado digamos assim, que elas pudessem usar.

Pergunta: Dentre os tipos de véus existentes, qual o significado do hijab para o islamismo?

Professor Mahmoud: A grande diferença entre eles [os tipos de véu] está ligado às várias culturas onde eles surgiram. Vou-lhe dar o exemplo da burqa. Há vários registos de que a burqa nem sequer terá surgido num contexto islâmico. Então, há, sobretudo, dois registos históricos que explicam o surgimento da burqa. Um deles diz respeito a uma comunidade que terá vivido, uma comunidade de mulheres, que terá vivido na zona do Iêmen, muito antes do Islão, e que fazia o culto de uma deusa da fertilidade, deusa Iris, e as mulheres que faziam esse culto, faziam parte de um grupo de mulheres que eram prostitutas, então, para não serem estigmatizadas pelo resto da comunidade, então, elas cobriam todo o corpo, porque o resto da comunidade, não as estigmatizava, nem sequer reconhecia quem eram as mulheres que faziam esse culto, esse é um dos registos. O outro registo diz respeito também a uma outra comunidade, que terá existido até num local que nós ouvimos falar recentemente, na zona de Palmira, que fazia parte da civilização suméria, e que fazia também o culto de um deus pagão, que era o deus Bel, e as mulheres, igualmente, usavam esse tipo de vestimenta que é semelhante à burqa. Ora, quando nasceu o islão, e acabou por acontecer com os outros trajes, acabou por assimilar peças de vestuário que já estavam integradas nessas culturas anteriormente. Então, como eu lhe disse há pouco, o que difere entre elas é, sobretudo, o contexto onde elas surgiram. O Islão não diz que 
as mulheres tenham que usar a burqa, o niqa, a shayla, o chador. O chador até está muito mais ligado ao Irão, ao contexto iraniano, onde se usa mais, ligado mais ao xiismo. O Alcorão só diz que as mulheres devem tapar os atrativos, os seus adornos corporais, só diz isso. Agora, a grande diferença que existe entre eles, diz respeito, sobretudo, a essas questões, as questões culturais e políticas. Portanto, não há uma imposição por parte do Islão a nenhuma vestimenta em particular, elas surgiram em contextos diferentes e acabaram por serem assimiladas pelos vários contextos, pronto, que terão absorvido esses costumes que já existiam. É essa a razão de tantas diferenças, entre tantos trajes diferentes.

Pergunta: O hijab é o modelo mais comum, o mais usado?

Professor Mahmoud: Sim. É o mais usado no mundo islâmico sim. Os outros, até porque o Islão, nós temos Islão desde a Indonésia, passando pela Europa, portanto, uma série de Países, tem a ex-União Soviética, por exemplo, até o Brasil. O hijab é, de facto, o mais usado. Até porque, em alguns Países, alguns teólogos fizeram-se valer de alguns hadices $^{2}$ para dizer que as mulheres não podiam deixar o rosto à mostra nem as mãos, ora, no Alcorão não refere isso. Há alguns hadices que referem essa questão, e há um hadice que o Profeta Maomé usou, quando viu a irmã da Aisha, Aisha foi uma das esposas do Profeta Maomé, viu a irmã descoberta e disse ela se deveria cobrir, mas poderia deixar, apenas as partes que poderia deixar à mostra, portanto, seria o rosto e as mãos. Ora, há teólogos, até por uma questão muitas vezes de poder do homem em relação à mulher, em relação a algumas sociedades, fizeram-se valer de alguns hadices que são falsos, para promoverem determinado tipo de vestimenta, que eles achavam que era a vestimenta mais adequada, o niqab, a shayla, ou outras. Portanto, o Islão não proíbe que a mulher mostre o rosto ou as mãos, daí que o hijab seja, de facto, aquele que é transversal a toda a sociedade islâmica. Agora, por exemplo, na Arábia Saudita, é obrigatório que a mulher use o niqab, não pode usar só o hijab, todas as mulheres sauditas têm que usar o niqab, que é imposto pelo próprio Estado, por isso que eu estava a dizer há pouco que, quando há uma lei que proíbe, aí podemos dizer que há uma obrigatoriedade, caso contrário, não há, nós podemos ir à Turquia, ao Marrocos, até à Síria, por exemplo, em que as pessoas livremente escolheriam a vestimenta que achavam mais adequada para seguir seus preceitos religiosos.

\footnotetext{
${ }^{2}$ Hadice ou Sunnah: A Hadice, ou Sunnah, "é a segunda fonte de onde os ensinamentos do Islam [Islão] são tirados. Hadice, literalmente, significa transmitir, comunicar ao homem, mas na terminalogia muhadithin, Hadice significa os ditos do Profeta, suas ações ou a prática de sua aprovação silenciosa de uma ação ou prática. Hadice e sunnah comumente se confundem entre si, mas algumas vezes têm sentidos diferentes". Cfr. Islam em Linha. [em linha]. [Consultado em 06 de agosto de 2018]. Disponível em http://islamemlinha.com/.
} 
Pergunta: Existe uma discussão jurídica e sociológica sobre o véu ser ou não uma vestimenta religiosa/símbolo religioso, pois, com base no que diz o Sagrado Alcorão: Ó Profeta, dize a tuas esposas, tuas filhas e às mulheres dos fiéis que (quando saírem) se cubram com as suas mantas; isso é mais conveniente, para que distingam das demais e não sejam molestadas; sabei que Deus é Indulgente, Misericordiosíssimo (Alcorão, 33:59), alguns argumentam que, uma vez não sendo o seu uso obrigatório, mas sim uma faculdade, o véu não poderia ser considerado um símbolo religioso. Com base nisto, perguntamos: Para o Islão, o véu é ou não considerado um símbolo religioso?

Professor Mahmoud: Nós, se pegarmos o sentido do véu, de uma forma abstrata, nós sabemos que o véu não é nem foi só usado pela tradição islâmica, se nós olharmos, por exemplo, para as irmãs católicas, se nós olharmos até para os hindus, se olharmos até aqui para o contexto português, até bem pouco tempo, na altura do antigo regime, era comum as mulheres irem à missa com o véu. Podemos dizer que não é exclusivo da tradição islâmica o uso do véu, não é obrigatório de facto, é uma prescrição, portanto, a não ser que exista, como lhe disse, algum País que obrigue por lei ao uso, ele não é obrigatório, é uma prescrição. Agora, o que é certo? É que, eu acho que muitas vezes o véu também é usado pelas mulheres, como tem um significado, um sinônimo da sua liberdade religiosa e da sua identidade religiosa, tal como a barba comprida, por exemplo, é para os homens, tal como o topi, aquele chapeuzinho feito em crochê, que é utilizado pelos homens, ou seja, não sendo obrigatório, eu acho que muitas vezes ele é usado como símbolo da identidade religiosa de alguém que vive a sua religião em privado e pronto, faz questão, porque é livre de fazer, de usar o hijab e o homem de usar a barba nos vários contextos onde está integrado.

Eu acho que o que se tem passado é de fato uma exacerbação de algumas questões ligadas aos símbolos religiosos que não valem mesmo a pena, são inócuos, não produzem nenhum efeito pacífico, antes pelo contrário, porque, muitas vezes, essa proibição por parte do Estado leva a um reforço daquilo que eu acho que são formas de pensamento resistentes em relação a essas proibições. E essas formas de pensamento resistentes, por exemplo, em França, eu vou-lhe dar o exemplo, em França, quando se começou a discutir a problemática do hijab, sobretudo, com meninas que iam à escola e nas aulas de educação física se recusavam a tirar o hijab, então, a escola nunca entendeu que elas pudessem usar o hijab, proibiu, e os pais fizeram uma coisa muito simples, um comportamento de resistência que foi retiravam as crianças da escola, e eu acho que é sempre isso que acontece, quando se tenta ver de qual lado a corda vai partir, esticando de um lado, esticando de outro, as coisas nunca vão funcionar, porque não há um 
entendimento tolerante em relação a isso. Penso que, para a sociedade, o fato de uma mulher usar o hijab ou o fato de um Padre usar um fio d'ouro com uma cruz não é, da minha opinião, nenhum insulto. Eu acho que há comportamentos muito mais insultuosos na sociedade, e nós estamos de fato a deixar passar e estamos a preocupar com uma espécie de perseguição àquilo que é sagrado.

Pergunta: Nos últimos tempos, a Europa tem vivido um clima de tensão com a comunidade islâmica, adotando medidas restritivas à liberdade religiosa, principalmente das mulheres muçulmanas. Seguindo na contramão de Países como França e Bélgica e até mesmo o Tribunal Europeu dos Direitos do Homem (por exemplo, caso Dahlab v. Suíça, de 15 de fevereiro de 2001), a Alemanha priorizou a liberdade religiosa e vetou a proibição do uso de símbolos religiosos por professores de escolas públicas. Acompanhando os noticiários, podemos ver que a Alemanha, ao contrário da França, apresenta um clima bem menos tenso de convivência com a comunidade islâmica. $O$ senhor acredita que o excesso de restrições pode gerar mais animosidade, levando exatamente para o caminho oposto ao da paz e da segurança buscadas? Professor Mahmoud: Sim, eu não tenho dúvidas sobre isso. Eu acho de facto que este caminho e, pegando naquilo que estávamos a conversar antes da entrevista, o caminho que alguns Países têm feito está diretamente relacionado com uma incompreensão do conceito de laicidade. Então, têm quase que tornado a laicidade como um partido político e aí deixa de ser laicidade e tornase laicismo. E laicismo nesse sentido em que esses Países o têm utilizado, é sobretudo uma perseguição a tudo aquilo que é religioso, tudo aquilo que é sagrado. Na minha opinião, eu acho que não há razão nenhuma para a Europa ter esse discurso, ter essa narrativa, que uma narrativa de dessacralização do mundo, de destruir tudo aquilo que é religioso, porque, na verdade, como lhe disse há pouco, eu acho que o uso do véu ou do turbante, por parte dos Sikh, ou o uso de um outro símbolo, do crucifixo por parte dos católicos, não será isso que irá causar problemas à sociedade. Acho que este clima de provocação constante, de proibição constante e de imposição daquilo que se considera por muitos Países como uma lei do Estado, muitas vezes invocando uma situação de segurança do próprio Estado, para proibir esses símbolos, acho que é um problema, e acho que é um problema que tem levado a algumas atitudes radicais, que, obviamente, que não podem ser nunca compreensíveis, mas que funcionam quase sempre como formas de resistência a essas imposições por parte do Estado, que é entendido por muitos crentes como uma tentativa destrutiva daquilo que é sagrado, portanto, na minha opinião, não tenho dúvida nenhuma de que este é um péssimo caminho a seguir. 
Pergunta: O Senhor sabe de algum caso de preconceito contra praticantes do islamismo, ocorrido em Portugal?

Professor Mahmoud: Nós, aqui em Portugal, temos um caso muito parecido com esse [o julgado do TC alemão, de 27 de janeiro de 2015], não com uma professora, mas com uma senhora líbia, que, em junho de 2016, quando foi defender sua tese de doutoramento em medicina dentária, um professor que estava presente, que fazia parte dos arguentes que iam avaliar e que é da Universidade de Coimbra. Ela fez questão de usar o hijab na sua apresentação e, simplesmente, foi proibida por esse professor de fazer e ela teve que pedir uma autorização especial à embaixada da Líbia para poder fazer.

Mas, há muito casos aqui com a comunidade portuguesa [casos de discriminação contra muçulmanos], sobretudo durante o Ramadão. Ainda há pouco, estive a falar com uma senhora também, uma investigadora da Universidade de Coimbra, que está a fazer um estudo sobre islamofobia, e falávamos sobre isso. Aqui em Portugal há muitos comportamentos desse gênero de discriminação da liberdade religiosa ou de violação da liberdade religiosa, sobretudo, durante o Ramadão, por exemplo, que temos várias pessoas, que obviamente, durante o Ramadão estão muito mais frágeis para poderem trabalhar e, normalmente, os patrões não têm um entendimento muito razoável em relação a isso. Mas, nós, normalmente, tratamos disso de forma privada [por isso não é levado a juízo] dentro da comunidade e tentamos aconselhar sempre as pessoas de forma a que sejam pacientes e que entendam, que não levantem grandes problemas em relação a isso, que continuem a viver a sua fé, sejam pacientes, peçam a Deus que muitas vezes ajude a dar a volta ao comportamento dessas pessoas que são mais ignorantes, entre aspas, e que vivam discretamente esse momento, tentando levar a situação a bom termo, sem causar grandes problemas ao resto da sociedade. 


\title{
$\underline{\text { Anexo B }}$
}

Transcrição do áudio da entrevista concedida pelo Sheikh David Munir (Imã da Mesquita Central de Lisboa)

\author{
Local: Mesquita Central de Lisboa
}

Data: $15 / 11 / 2017$

\section{Horário: 14h30}

Pergunta: Qual a importância do uso do véu?

Sheikh Munir: No Islão, o véu, isto é, cobrir a cabeça, os cabelos, faz parte do vestuário de uma muçulmana, é tão simples como isso. Não se trata de considerar como um símbolo, porque no Islão não há símbolos, não havendo símbolos nós podemos dizer que uma parte do vestuário passa a ser simbólico. Agora, do outro lado, a prática do Islão é muito pessoal. Portanto, há muçulmanas que usam o véu e há muçulmanas que não usam. O que é importante no Islão é cobrir todo o corpo, exceto a face.

Há Países, há comunidades, há famílias, há pessoas, que dão para além de cobrir a cabeça, excedem e dizem que não, tem que se cobrir também a face ou parte dela. Por isso, que quando se fala em véu islâmico, as pessoas que não têm muito conhecimento ficam confusas.

Cobrir a cabeça faz parte do vestuário de uma muçulmana, é corânico, é versículo do Alcorão que fala sobre isso, portanto, nem sequer podemos refutar ou discutir, ou a pessoa aceita ou não aceita. Agora, como eu disse desde o início, considerar o véu um símbolo é um erro. Portanto, em que contexto nós podemos falar em proibição do uso do véu? O véu ou cobrir a cabeça, o hijab, aquilo que é mais comum também a expressão, não tira a liberdade da mulher, não oprime a mulher, não a considera inferior ao homem, percebe? Nada disso é discutido, nada disso é falado, porque a pessoa não se sente oprimida, a pessoa não sente que lhe estão a retirar a liberdade, pelo contrário. Há muçulmanas que não usavam, começaram a usar e sentem-se mais seguras, mais protegidas, menos cobiçadas, podemos assim dizer.

$\mathrm{O}$ véu não é só cobrir a cabeça num sentido amplo. $\mathrm{O}$ véu também tem que ser um vestuário modesto, um vestuário que não chama a atenção, um vestuário que não faça parar o trânsito, podemos dizer assim, um vestuário que não haja provocações, isto também é importante e faz parte daquilo que nós queremos explicar, o traje ou vestuário islâmico.

O Islão é um código de vida, é uma forma de estar na vida e, nesta forma de estar na vida, fala de vários aspetos. 
Há práticas que nós temos no Islão, incluindo o vestuário, mais concretamente, incluindo o vestuário da mulher, é bíblico, portanto, vem no antigo como também vem no novo testamento, como é que uma cristã ou como é que uma judia deve-se vestir. Por isso que as irmãs, as freiras, têm um vestuário, elas andam com um lenço; as judias também andam, aquelas que são mais religiosas ou aquelas que querem pôr em prática sua religião. Acontece que, como em alguns Países islâmicos, os partidos mais religiosos ou os partidos com alguma conotação com o Islão, os seus seguidores são pessoas, mais concretamente as mulheres, a maioria são aquelas que usam o lenço, então é normal que, quando essa força política vença as eleições e é normal quando isto atravessa as fronteiras, e quando nós falamos em atravessar as fronteiras, quer dizer, quando vem para o Ocidente, algumas pessoas ficam com algum receio, ficam assustadas, que isso agora passou a ser o quê? Viver no Ocidente, havendo a liberdade religiosa, este é o tal princípio que o Ocidente tem, que, infelizmente, muitos Países islâmicos não têm, não têm esse respeito pela liberdade religiosa. Tendo esse respeito pela liberdade religiosa, não se compreende como é que é possível, como que você vai proibir algo que é obrigatório? É como se fosse, imaginemos, é como se fosse proibir os muçulmanos de fazerem suas orações ou, por exemplo, obrigassem os muçulmanos a consumirem álcool, sabendo que é proibido.

Portanto, aqui há um receio, há um medo de alguns políticos, muitas das vezes, de anexarem essas pessoas simples cidadãs europeias que, simplesmente, querem usar o lenço. Imaginemos uma muçulmana convertida, uma europeia que estudou o Islão, convictamente, identificou-se com ela e quer ser muçulmana, abraçou o Islão, ninguém pode oprimir! Nem a sociedade a pode proibir, nem o Islão a pode proibir, portanto, a pessoa que quer abraçar o Islão, o Islão não pode proibir. No entanto, esta pessoa, mais concretamente a mulher, aceitou o Islão e quer começar a usar o lenço, quer começar a usar o hijab, porque é obrigatório! O que irá acontecer com essa senhora? Tem sua vida profissional, tem sua atividade profissional, é uma pessoa que exerce sua profissão, é uma pessoa que é competente naquilo que faz, só porque, simplesmente, aceitou o Islão e que, ao aceitar o Islão, é normal que, significa submissão voluntária, é normal que alguns hábitos são alterados, desde a alimentação e desde a própria convivência, podemos dizer assim, o vestuário, se ela começa a vestir o hijab, o lenço, por que é que a sociedade não irá aceitar? Ela não está a prejudicar a ninguém! Não está a incomodar a ninguém! Do outro lado, se nós temos o burqa ou o niqab, por razões de segurança, aí é que está, por razões de segurança, que também nós temos que zelar a nossa segurança, uma vez que não é obrigatório o uso de niqab o uso de burqa, não sendo obrigatório, mas se ela quiser vestir, desde que não ponha a segurança em causa, tudo bem. Mas, se houver uma autoridade que queira, por exemplo, 
revistar a senhora e que queira saber se é mesmo uma senhora ou se não é, eles, a autoridade, tem esse direito.

Há uns anos atrás, o receio que as pessoas tinham era com os homens que tinham barba, barba comprida, então, era um pouco assustador. Hoje, boa parte dos jovens, no Ocidente, deixam crescer a barba. Depois, havia um certo receio dos homens, concretamente, que tivessem não só barba, mas que andassem de djellabia, que é esta túnica que eu tenho, no seu dia a dia, então, ali, as pessoas começaram a ter algum receio. Hoje, chegaram à conclusão de que muitos dos atentados, infelizmente, que aconteceram, no nosso continente, no Ocidente, agora, também na Europa, foram por jovens ou foram por pessoas que vestiam a civil e, então, passaram a ter receio das pessoas que tinham mochilas. Qualquer pessoa que tivesse mochila e que se deixasse uma mochila ou algo abandonado, então, era logo um certo receio, e, também, começaram a notar que também o hijab, o uso do hijab, pode provocar alguma insegurança na nossa sociedade. As mulheres sempre vestiram hijab, as cristãs vestiam hijab, as judias vestiam hijab, as muçulmanas também vestem o hijab. Só que a reação que os políticos têm, na Europa, a reação que alguns sociólogos, alguns historiadores têm, alguns acadêmicos têm, alguns jornalistas têm, é uma reação negativa, é uma reação de repúdio, percebe? E Portugal não tem sido exemplo, isto é, Portugal tem sido um bom exemplo de uma boa convivência, por isso que há muçulmanas que, quando andam na rua, usam o lenço. Nós não somos mais que 50 mil muçulmanos, portanto, não houve nenhum caso, em que eu soubesse, que uma muçulmana deixou de trabalhar ou foi impedida de trabalhar só por andar com o lenço ou que tivesse sido impedida de entrar no espaço público só por usar o lenço. Agora, há muçulmanas que, para evitarem qualquer problema na empresa onde estão, ou no trabalho onde estão, optam por não vestir.

Pergunta: O uso do véu é realmente facultativo, segundo o Sagrado Alcorão?

Sheikh Munir: Acontece que a própria pessoa, o próprio crente, não pode dizer que não é obrigatório. Uma coisa é a pessoa não fazer, é entre eu e Deus, eu que vou ter que responder a Ele, outra coisa é a pessoa dizer que não é obrigatório, ou dizer que é obrigatório uma coisa que não seja. Uma coisa que não é obrigatório, eu dizer que é obrigatório, e uma coisa que é obrigatório, eu dizer que não é obrigatório, então eu estou pondo a minha crença em causa, percebe? Por isso, eu não vejo o lenço ou o hijab como discriminatório, como algo que seja considerar a mulher inferior, ou que ela seja submissa, ou que seja oprimida, nada disso! E nós 
podemos perguntar às muçulmanas. Há famílias em que, por exemplo, são 3 filhas, uma veste e duas não vestem.

Pergunta: Como é a integração dos muçulmanos, notadamente, os imigrantes, com o restante da comunidade ocidental?

Sheikh Munir: A integração não significa que eu tenha que fazer tudo aquilo que você faz, isto não seria integração, isto seria imitação.

Há um outro problema que é sobre a identidade nacional dos muçulmanos, porque os muçulmanos que vivem no Ocidente, tirando Portugal, os que vivem no Ocidente, uma boa parte, não se identificam como europeus, mesmo tendo nascido na Europa, mesmo tendo nascido e crescido, estudado, convivido e, provavelmente, nunca foram a nenhum País islâmico, mas só que como os pais ou os antepassados vieram de um dos Países islâmicos ou de um País árabe, então, quando nós perguntamos:

- Desculpe, você é francês? É alemão?

- Não, eu sou marroquino. Não, eu sou argelino.

- Mas, você nasceu em França.

- Ah, mas os meus pais...

- Eu não estou a perguntar sobre seus pais, eu estou a perguntar sobre você. Você tem cidadania europeia, você é europeu.

- Não, eu não sou europeu.

Por quê? Porque alguns teólogos dizem e disseram, através de um pacto, que dizer que eu sou europeu é como se fosse que você estivesse a dizer que eu não sou crente. Percebe? E mentalizaram isso nas pessoas. Dizer que sou europeu é dizer que eu não sou crente. Ou dizer que você é europeu e como se fosse que você estivesse a dizer que eu sou cristão, porque a religião maioritária no Ocidente é a cristã. Isso está errado, e, como eles tiveram essa informação, e nem sequer procuraram saber o que é real o que não é real.

Depois, na Europa, e quando eu falo Europa estou a excluir Portugal, criaram-se guetos, lugares onde uma boa parte da população pertence a uma religião ou a uma crença, isolaram-se, a sociedade em geral não os quis e eles também não se integraram, ficaram anos e anos, estamos a falar em décadas. Só que, com a globalização, eles querem sair. Antes, os pais só saiam, trabalhavam e depois regressavam, hoje, os filhos querem conviver. Então, nesta convivência, há um choque, porque estavam habituados a uma prática, a uma forma de pensar, uma forma de estar, e, aqui, a sociedade em geral tem uma outra forma de estar, outra forma de ser, outra 
forma de ver as coisas e, quando há essa convivência, acaba por haver choques. Por exemplo, dois irmãos, ele e ela muçulmanos, de outro lado, dois irmãos cristãos, ele e ela, a irmã (do cristão) é capaz de brincar com o irmão e os amigos do irmão, a irmã do muçulmano é capaz de brincar só com o irmão, não com os amigos do irmão, percebe? Então, Por quê? Porque não está preparada, não está habituada. A grande questão que se coloca, não estamos aqui a tentar avaliar se é permitido, se não é permitido. Como, culturalmente, nunca se conviveram ou sempre houve esta separação e, de repente, mesmo o próprio irmão não está preparado para conviver ou para brincar, estamos a falar de idade de brincadeira, idade de criança, não está preparado para brincar com a irmã do amigo. Não está preparado, porque não lhe prepararam dessa forma. A outra rapariga está à vontade para brincar com os amigos do irmão, porque são amigos do meu irmão, irão me respeitar.

Pergunta: Nos últimos tempos, a Europa tem vivido um clima de tensão com a comunidade islâmica, adotando medidas restritivas à liberdade religiosa, principalmente das mulheres muçulmanas. Seguindo na contramão de Países como França e Bélgica e até mesmo o Tribunal Europeu dos Direitos do Homem (por exemplo, caso Dahlab v. Suíça, de 15 de fevereiro de 2001), a Alemanha priorizou a liberdade religiosa e vetou a proibição do uso de símbolos religiosos por professores de escolas públicas. Acompanhando os noticiários, podemos ver que a Alemanha, ao contrário da França, apresenta um clima bem menos tenso de convivência com a comunidade islâmica. $\mathrm{O}$ senhor acredita que o excesso de restrições pode gerar mais animosidade, levando exatamente para o caminho oposto ao da paz e da segurança buscadas?

Sheikh Munir: Até nós não aceitarmos o outro como nós, haverá sempre essa tensão, porque essa convivência sociológica de eu e eles, então eles criam tensão, eles acham que os outros que estão a criar essa tensão, estão-nos a restringir, estão-nos a retirar a liberdade, e esses acham que eles querem impor a sua forma de estar, a sua vida a nós, portanto, tem que haver aqui um equilíbrio, o Islão não obriga a pessoa, mas também não proíbe. Mas isto não é de agora, o que nós estamos a ver, agora, é o fruto do que foi semeado há décadas e você tá a colher aquilo você semeou. Os Países da Europa, França, Alemanha, Inglaterra, Bélgica, foram Países que encostaram sempre os imigrantes longe das cidades, no bairro das latas. Acontece que, provavelmente, à volta desse bairro foram criando shoppings e etc., mas o próprio bairro não tem a mesma estrutura, por quê? Porque "não são dos nossos", agora, se você quer viver na mesma sociedade, nunca poderemos dizer "eles não são dos nossos", eles têm que pertencer à nossa sociedade, mas, para isso, tem que haver uma aproximação e havendo diálogo baixa a 
tensão, não há diálogo, estão de costas viradas, porque o outro é considerado inferior, porque, do outro lado, há os que se acham superiores, isso faz com que as pessoas fiquem de costas viradas, isso faz com que a pessoa deixe de ter interesse nacional, deixam de zelar e, eu estava a dizer agora há pouco, se eles não consideram Europa, França o meu País, eu posso destruir. A política externa de alguns Países da Europa para com o Médio Oriente também ajudou. A política externa de invasão, de influenciar aqui, de mandar tropas ali, essa coligação que se foi fazendo, afetou a muito e afetou também muçulmanos que vivem na Europa. Então, tudo isso é um conjunto de situações, que nós estamos a recolher o fruto que semeamos. 


\section{$\underline{\text { Anexo C }}$ \\ Transcrição do áudio da entrevista concedida pelo casal, Senhora Nadia Ettaouass e Senhor Islam Reis \\ Local: Rua de Santa Catarina, Porto/PT \\ Data: $28 / 12 / 2017$ \\ Horário: $12 \mathrm{~h} 00$}

Pergunta: A senhora usa o hijab? Em caso afirmativo, constantemente ou apenas em algumas ocasiões?

Sra. Nadia: Usei o hijab [desde os] seis anos, cheguei Portugal, tirei o hijab. Sim, sim, no Marrocos sim, normal, toda a gente usava lá e as minhas irmãs também.

Pergunta: Aqui, em Portugal, ainda existe alguma ocasião em que a senhora use o hijab?

Sra. Nadia: Uso, por exemplo, vou à Mesquita é obrigatório, e se for a algum sítio pra rezar, casa de alguém pra rezar, também tem que usar.

Pergunta: E para andar na rua, no dia-a-dia, a senhora usa o hijab?

Sra. Nadia: Não.

Pergunta: Na época em que a senhora trabalhava, aqui em Portugal, a senhora encontrava alguma resistência ao uso do hijab, no local de trabalho?

Sra. Nadia: Muitas, mesmo grávida, faziam de propósito, mandavam buscar coisas pesadas, de propósito, porque tinha mais pessoas que poderiam buscar, mas me mandaram, tem que ser eu, é de propósito, cheguei a perder sangue, por causa do peso, mas foi $100 \%$ eu que meu chefe disse pra mim pra fazer essas coisas, até que eu nem aguento mais e foi embora.

Pergunta: E, nesse período, a senhora usava o hijab, no local de trabalho?

Sra. Nadia: Não, não usei.

Pergunta: O seu chefe apenas sabia que a senhora era muçulmana e, mesmo sem usar o hijab, a senhora sofria preconceito?

Sra. Nadia: Sim. 
Pergunta: Sabemos que o véu não é um símbolo religioso, mas sim um código de vestimenta do Islão. Qual a importância do uso do véu para a senhora?

Sra. Nadia: Que é uma ordem de Deus e eu quer fazer esta ordem, sente muito melhor, porque se é obrigatório tem que fazer.

Pergunta: Como a senhora se sente ao ser impedida de usar o véu?

Sra. Nadia: Sente mal, sente mal... Gostava muito de ser normal, de usar normal e fazer minha vida igual a Marrocos, claro que gosto muito mais. Se for assim, volta já agora a usar o hijab e faço minha vida, se ninguém olha pra mim de maneira diferente.

Pergunta: O que a senhora pensa a respeito dessa onda de restrições ao uso do véu em alguns Países da Europa, notadamente, em França?

Sra. Nadia: Não é nada bom, porque elas, coitadas, são muito apegadas e muitas delas não podem entrar nas faculdades, nas escolas, por causa disso. E isso é um pedido de Deus para as pessoas, não é porque estão a fazer mal a ninguém, mas, infelizmente, ninguém procura saber se estão a fazer mal ou não.

Sr. Islam: É uma questão de respeito à religião. Como cristãos, muçulmanos, quando têm uma fé, tentam agradar a Deus para tudo aquilo que lhes foi ordenado. Nesse caso, à muçulmana, é ordenado que se deve usar o hijab, vestimentas largas, com o sentido da mulher ser respeitada, porque muitas vezes o ser humano olha para a mulher pela sua curvatura, pelo seu físico e não pela sua maneira de ser, a verdadeira pessoa que ela é, e o hijab protege isso, o hijab, com vestimentas largas, protege isso, porque se tu gostares de alguém olhas por aquilo que ela é e não por aquilo que ela aparenta ser, e isso é o que é ser muçulmano. Ela, como mulher muçulmana que não usa o hijab, ela fica triste, porque é uma coisa como qualquer religioso, devidamente dentro da religião, quer agradar ao Deus e, não podendo cumprir com uma das ordens que Deus, neste caso, nos deu, a mulher fica triste. É a mesma coisa como nos católicos, nós vemos uma freira que usa um lenço na cabeça, que é quase como se fosse um hijab, imagine se toda a gente começasse a dizer que as freiras não poderiam usar aquilo, com certeza que as freiras se sentiriam tristes, porque foram incutidas toda a vida a usar aquilo, e se a obrigassem a tirar iriam ficar muito sentidas, e o respeito religioso é mesmo isso, é deixarem usar, mas, infelizmente, as pessoas não olham para a crença, mas sim para aquilo que têm na cabeça e para aquilo que veem na televisão todos os dias, essa é a maior tristeza que existe no mundo. 
Pergunta: Muitas pessoas dizem que o véu islâmico é uma forma de subjugar a mulher, de colocá-la em posição de submissão ao homem. Sabemos que tal entendimento não faz parte do islamismo. $\mathrm{O}$ que a senhora teria a dizer às pessoas que acreditam ser o véu uma forma de inferiorizar a mulher?

Sra. Nadia: Aonde elas ouviram ou viu isso? Elas têm que falar: olha, li isso num sítio aqui. Não é porque eu pensei que essa senhora vai fazer aquilo, isso não dá uma justificação. Só porque eu estou contra uma pessoa, não posso dizer o que ela é. Pra mim, não tem lógica nenhuma. Tantas pessoas a dizer coisas que não tem lógica e não é verdade, porque só pra julgar as pessoas, não olham nem no Alcorão, que é nosso Sagrado, nem foi a nenhuma Mesquita e ouviu alguém a falar disso. Não. Mas, julgaram as pessoas desta maneira. Não gosto, não tem lógica e fico furiosa, é normal. Não gosto. Isto deixa as pessoas muito triste.

Sr. Islam: Em primeiro lugar, as pessoas deviam olhar e ler o que está no Alcorão e, no Alcorão, diz que tanto homem como mulher tem o mesmo direito de igualdade, ponto final. Vendo no Alcorão que tanto homem como mulher têm o mesmo direito de igualdade, as pessoas não podem julgar a mulher muçulmana, por causa [do véu]. Falamos aqui em casos, estamos a falar em caso de cultura, e cultura é uma coisa, religião é outra, os costumes é uma coisa e a religião é outra. E o que a religião diz é que o homem e a mulher têm o mesmo direito de igualdade. Não porque a mulher usa o hijab que é inferior a mim e não é porque eu uso um topi ou a barba ou túnica ... que eu sou superior à mulher, não. Na última palestra do nosso Profeta Mohamed, ele dizia, uma das coisas que ele salientou foi que respeitem as vossas mulheres, acho que isso diz tudo. Não vamos julgar aqui as religiões por causa dos costumes, porque todas as terras, as comunidades têm os seus costumes. A Arábia Saudita, eles usam porque é o que eles têm na cabeça, não é porque a religião obriga, temos que fazer essa comparação de uma coisa a outra e separar as coisas. Uma cosia é o que uma comunidade usa e outra coisa é o que diz o Alcorão. O que diz o Alcorão é o que prevalece, pronto. Vamos falar em África, em Guiné Bissau, o homem tem 7, 8, 9, 10 mulheres, isso é tudo por causa da comunidade, que é assim que pensa, a mentalidade daquela comunidade é aquela, mas não é isso que diz na religião. Isso tudo é porque a poligamia foi criada no Islão, mas temos que perceber que a poligamia foi criada no Islão sim, mas para salvaguardar e proteger as mulheres que perdiam os homens na guerra. Os homens iam pra guerra e as mulheres ficavam em casa com os filhos e muitas vezes eles morriam e as mulheres ficavam vulneráveis, por quê? Porque eram os homens que sustentavam a casa, e ficavam filhos órfãos e mulheres vulneráveis. Então, foi criada a poligamia, para que um homem, que fosse mais abastado, pudesse tomar conta daquela família, mas uma coisa que 
é preciso salientar é que o homem tomava conta daquela família, mas não queira dizer que fosse ter relações sexuais com aquela mulher, não, era só para salvaguardar e proteger as crianças e para que a família que perdeu o pilar continuar sólida e pudesse sustentar a família, foi por isso que foi criada a poligamia.

Pergunta: Então, Sra. Nadia, a senhora, como muçulmana, nunca se sentiu inferior aos homens e sempre viveu sua vida como bem quis?

Sra. Nadia: Sim.

Pergunta: Os senhores têm filhos em idade escolar?

Sra. Nadia: Um filho de dois anos. Ele está no infantário.

Pergunta: É um infantário secular ou religioso?

Sra. Nadia: Não, não, não. Normal. Mas, tem uns pedidos, no infantário. Meu filho não pode comer gelatina, não pode comer carne de porco. Meu filho, agora, ainda não estou a fazer, mas não quer que ele está na hora de oração, não é porque estou contra, é porque também quero meu filho segue minha religião. Contra a minha vontade, obrigatório vai aprender algumas coisas, mas, mesmo assim, na minha casa ele tem que saber que a religião é aquela, estamos muçulmanos, fazemos Ramadão, ajudar um ao outro. Eu tenho que ajudar, tanto eu como o meu homem, ajudar muito mais, não vai ser nada fácil, mas tem que ajudar muito mais para ele estar com nós, não é contra nós.

Pergunta: Existe alguma resistência do infantário em atender a esses pedidos especiais?

Sra. Nadia: Não, não. Pra já, graças a Deus, tá tudo bem. Compreenderam e desde o início nunca tive problemas

Sr. Islam: No caso do Professor Mahmoud, tem a filha na escola primária, e ele falou pra mãe que era muçulmano e queria que a filha fosse por [esse caminho] e a nutricionista da escola teve o cuidado de criar uma ementa semanal para a filha dele. Nós temos a falar aqui que temos o lado bom e o lado mau. Não podemos falar apenas do lado mau. Há coisas boas que existem. Sra. Nadia: Há coisas boas, há coisas boas, há coisas muito boas. Isso eu também falo, por exemplo, no infantário do meu menino, são pessoas unidas, te ajudam o máximo possível, compreendem, olham pra nós [como] pessoas normais, falam conosco normal, gostam de nós, 
não temos problemas, tanto com os educadores como os pais das crianças, os pais aceitaram muito bem meu menino, não temos problema nenhum. Ainda bem!

Pergunta: Para finalizar nossa conversa, a Sra. Nadia poderia dar-nos um depoimento, falando como é ser uma mulher muçulmana em Portugal?

Sra. Nadia: Por exemplo, se for no meu País eu uso [hijab] e uma pessoa tá na rua com hijab é uma pessoa normal, respeitada, com muito respeito, muito mais que pessoas que não usa hijab, ninguém fala mal dela, mas, em Portugal, um bucadinho contrário, como eu disse, entrei [na loja] com a rapariga [usando o hijab] e o segurança sempre com nós, olhando o que pode fazer o que não. Na faculdade, que as pessoas têm mais outro nível, também não aceitaram a rapariga que está com hijab [referência ao caso de Coimbra, mencionado pelo Professor Mahmoud, em sua entrevista]. Em Portugal, tem que tirar o hijab, porque estamos na Europa, temos que aceitar o que está na Europa, mas acho muito mal, porque estamos na Europa, um País de liberdade, toda a gente pode fazer o que quer, mas... isso... Se eu entro com o hijab, toda a gente a olhar para mim de uma maneira não boa e eu não quero. Eu vou à Mesquita com o hijab, saio, vou a supermercado, só que tem que ser muito rápido, para ir embora, porque já não estou a sentir muito bem, e o meu marido sempre a dizer: "viste? Eu já te disse! Isso vai acontecer, por isso eu lhe disse [para] tirar”. Eu tirei, mas, realmente, eu não estou a sentir nada bem, mas estou obrigada a viver assim. Eu quero também fazer parte do que estou aqui, com meu marido, e também fazer o meu fé completo, mas, infelizmente, não dá para ser. 


\section{Anexo D}

Inquérito a professores de escolas públicas de Munique (Alemanha) - Respostas dadas nos meses de novembro e dezembro de 2017

\begin{tabular}{|c|c|c|c|c|c|c|c|c|c|c|c|}
\hline $\begin{array}{l}\text { Inqui- } \\
\text { rido* }\end{array}$ & $\begin{array}{l}\text { Idade } \\
\text { (anos) }\end{array}$ & Gênero & $\begin{array}{l}\text { Tempo de } \\
\text { profissão } \\
\text { (anos) }\end{array}$ & $\begin{array}{l}\text { Tem ou } \\
\text { teve } \\
\text { colegas } \\
\text { muçul- } \\
\text { manos }\end{array}$ & $\begin{array}{l}\text { A escola tem } \\
\text { regras para } \\
\text { uso de } \\
\text { símbolos } \\
\text { religiosos }\end{array}$ & $\begin{array}{l}\text { A escola tem } \\
\text { regra } \\
\text { especial } \\
\text { para uso do } \\
\text { hijab }\end{array}$ & $\begin{array}{c}\text { Ver pessoas } \\
\text { usando } \\
\text { símbolos } \\
\text { religiosos causa } \\
\text { desconforto }\end{array}$ & $\begin{array}{c}\text { Ver uma } \\
\text { professora } \\
\text { usando } h \ddot{j} \text { ab } \\
\text { causa } \\
\text { desconforto }\end{array}$ & $\begin{array}{c}\text { Ver pessoas } \\
\text { usando } \\
\text { símbolos } \\
\text { cristãos causa } \\
\text { desconforto }\end{array}$ & $\begin{array}{l}\text { O que pensa } \\
\text { sobre o } h i j a b\end{array}$ & $\begin{array}{c}\text { Tem } \\
\text { contato } \\
\text { com } \\
\text { muçul- } \\
\text { manos }\end{array}$ \\
\hline 01 & 30 & Feminino & 05 & não & não & não & não & não & --- & não conhece & $\operatorname{sim}$ \\
\hline 02 & 56 & Feminino & 33 & não & não & não & não & não & --- & $\begin{array}{c}\text { é parte de } \\
\text { uma tradição }\end{array}$ & $\operatorname{sim}$ \\
\hline $\mathbf{0 3}$ & 56 & Feminino & 31 & não & não & não & não & não & não & $\begin{array}{c}\text { é uma decisão } \\
\text { pessoal, só } \\
\text { não gostaria } \\
\text { que alguém } \\
\text { fosse } \\
\text { obrigado a } \\
\text { usá-lo }\end{array}$ & $\operatorname{sim}$ \\
\hline 04 & 53 & Masculino & 30 & não & não & não & não & $\begin{array}{l}\text { Hijab não, } \\
\text { mas Burqa } \\
\text { sim }\end{array}$ & --- & $\begin{array}{c}\text { é uma decisão } \\
\text { pessoal }\end{array}$ & não \\
\hline 05 & 30 & Feminino & 07 & não & não & não & $\operatorname{sim}$ & $\operatorname{sim}$ & --- & $\begin{array}{c}\text { não gosta de } \\
\text { ver pessoas } \\
\text { demonstrando } \\
\text { sua religião }\end{array}$ & não \\
\hline 06 & 52 & Feminino & 30 & não & não & não & $\operatorname{sim}$ & $\begin{array}{l}\text { Sim, porque } \\
\text { não é cristão }\end{array}$ & --- & $\begin{array}{c}\text { Pode ser } \\
\text { usado, mas } \\
\text { não em } \\
\text { prédios } \\
\text { públicos }\end{array}$ & $\operatorname{sim}$ \\
\hline 07 & 57 & Feminino & 32 & não & não & não & $\operatorname{sim}$ & $\begin{array}{l}\text { Sim, porque } \\
\text { não é a } \\
\text { tradição } \\
\text { alemã }\end{array}$ & não & $\begin{array}{c}\text { Pode ser } \\
\text { usado, mas } \\
\text { não na escola }\end{array}$ & $\operatorname{sim}$ \\
\hline
\end{tabular}

*Os inquiridos preferiram manter o anonimato. 